\title{
Hydrology and Water Quality of Reedy Creek in the Reedy Creek Improvement District, Central Florida, 1986-89
}

\author{
By Paul S. Hampson
}

U.S. Geological Survey

Water-Resources Investigations Report 93-4006 


\section{U.S. DEPARTMENT OF THE INTERIOR BRUCE BABBITT, Secretary}

U.S. GEOLOGICAL SURVEY

ROBERT M. HIRSCH, Acting Director

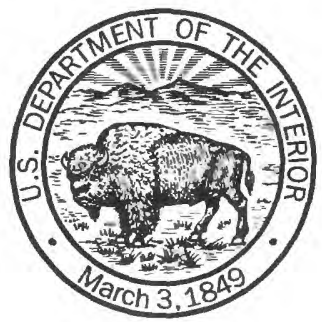

For additional information write to:

District Chief

U.S. Geological Survey

Suite 3015

227 N. Bronough Street

Tallahassee, FL 32301
Copies of this report can be purchased from:

U.S. Geological Survey Earth Science Information Center Open-File Reports Section Box 25286, MS 517 Denver Federal Center Denver, CO 80225 


\section{CONTENTS}

Abstract

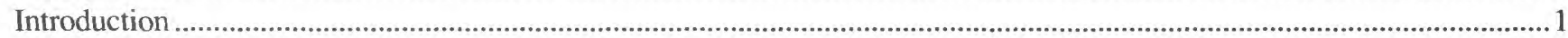

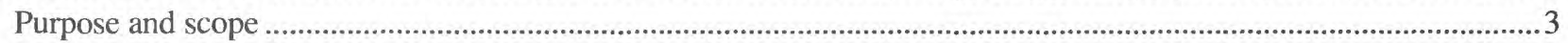

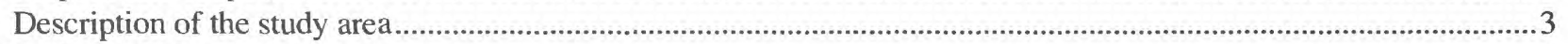

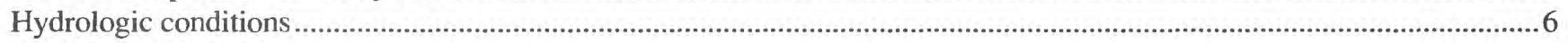

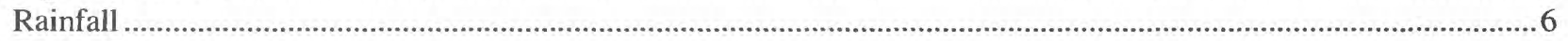

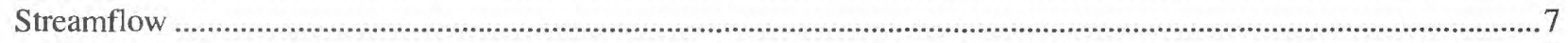

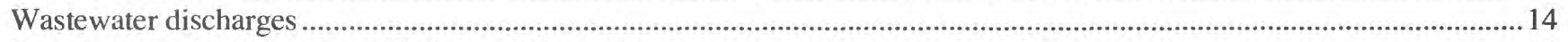

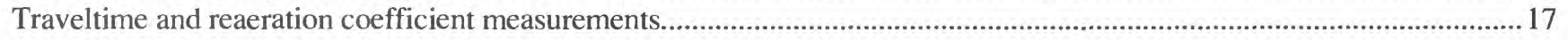

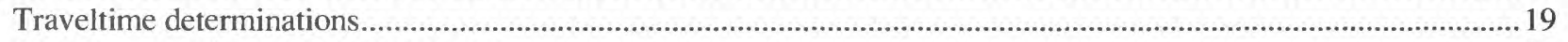

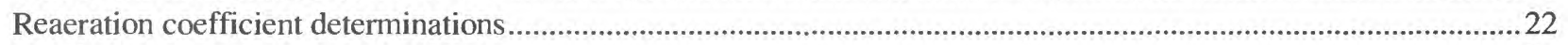

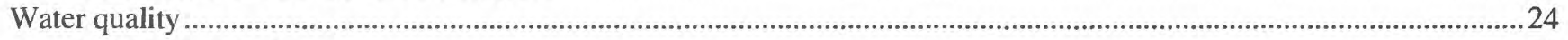

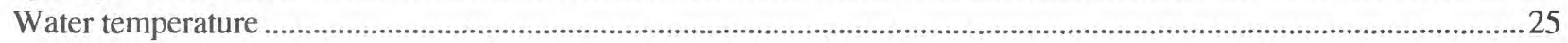

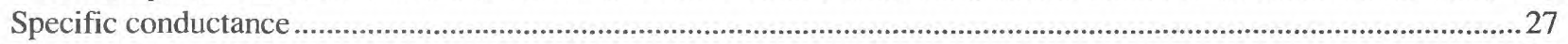

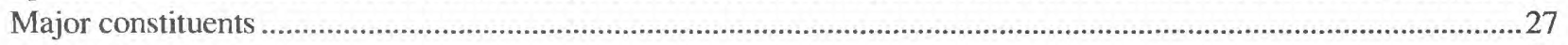

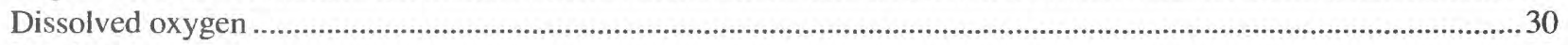

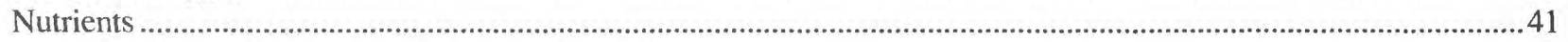

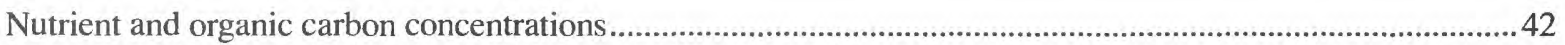

Nutrient loads into and out of the wetland conservation area .......................................................................4

Nutrient concentrations and loads associated with wastewater discharge to Reedy Creek ….............................48

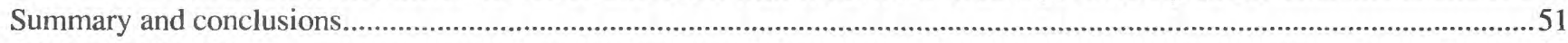

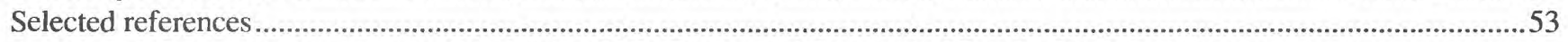

Appendix--Comparative water-quality data for U.S. Geological Survey and Reedy Creek Improvement

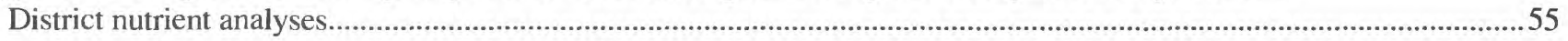

\section{FIGURES}

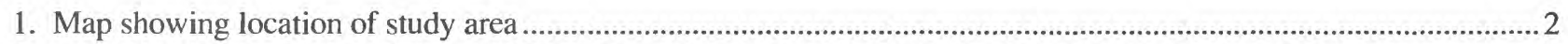

2. Map showing station locations and hydraulic structures within the Reedy Creek Improvement District..................... 4

3-9. Graphs showing:

3. Annual rainfall at the National Oceanic and Atmospheric Administration station at Kissimmee, 1930-89..........6

4. Mean monthly rainfall and deviations from the mean monthly rainfall, 1986-89, at the National Oceanic and Atmospheric Administration station at Kissimmee.................................................................... 7

5. Annual mean discharges for Cypress, Whittenhorse, and Davenport Creeks, 1967-89 water years...................... 8

6. Daily mean discharges for Cypress, Whittenhorse, and Davenport Creeks, 1986-89........................................ 10

7. Annual mean discharges for Bonnet and Reedy Creeks, 1967-89 …...............................................................11

8. Flow-duration curves for Whittenhorse and Davenport Creeks, and Bonnet and Reedy Creeks.........................12

9. Daily mean discharges at stations on Bonnet and Reedy Creeks, 1986-89.......................................................13

10. Map showing locations of stations, study reaches, and hydrologic features of the north and south wetland

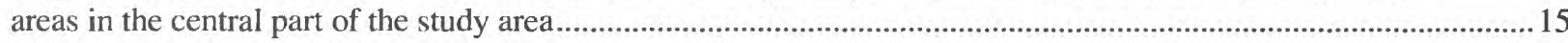

11-31. Graphs showing:

11. Monthly mean discharges for Reedy Creek at station 02266300 near Vineland and station RC18, 1979-89 ..... 16

12. Monthly mean discharges for the north wetland, south wetland, and percolation-pond areas; and the wetlands outflow, wastewater, and wetland contributions ........................................................................... 17

13. Monthly mean discharges during August 1988 to December 1989 for structure S-405, canal L-410, and the wetland system outflow; and Reedy Creek at stations 02266298 and PP7

14. Monthly mean discharges for Reedy Creek at station 02266300 (near Vineland) and 02266298 (above U.S. Highway 192), August 1988 to December 1989 ....................................................................... 19

15. Traveltimes and dye concentrations for Reedy Creek reaches A and B, August 17, 1988 ..............................2 20

16. Traveltimes and dye concentrations for Reedy Creek reaches A and B, November 3, 1988..........................21

17. Estimated traveltime for Reedy Creek reaches A and B based on discharge .................................................22

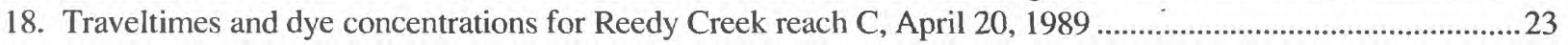

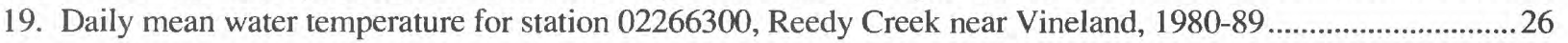


20. Hourly water temperature for three stations on Reedy Creek, May 4-5, 1989 .26

21. Daily mean specific conductance for station 02266300 , Reedy Creek near Vineland, 1980-89.

22. Monthly mean specific conductance for stations 02266298,02266300 , and 02266320 on Reedy Creek, 1985-89

23. Daily mean dissolved oxygen concentrations for station 02266300 , Reedy Creek near Vineland, $1980-89 \ldots . . . .31$

24. Daily mean dissolved oxygen concentrations for Reedy Creek near Vineland and Big Creek near Clermont, 1982-86

25. Dissolved oxygen duration curves for Reedy Creek near Vineland and Big Creek near Clermont. .34

26. Monthly mean dissolved oxygen concentrations for stations 02266298,02266300 , and 02266320 on Reedy Creek, 1984-88

27. Dissolved oxygen duration curves for stations $022662947,02266298,02266300$, and 02266320 on Reedy Creek, 1963-89

28. Hourly dissolved oxygen concentrations for three stations on Reedy Creek, November 8-11, 1988, and April 22-24, 1989.

29. Dissolved oxygen concentrations at stations 02266298 and 02266300 on Reedy Creek during a large storm on November 3-7, 1987

30. Dissolved oxygen concentrations at stations 02266298 and 02266300 on Reedy Creek during a moderate storm on October 11-13, 1987

31. Dissolved oxygen concentrations at stations 02266298 and 02266300 on Reedy Creek during two small storms on April 14-15 and April 18-19, 1989

32. Map showing location of wetland conservation area and stations used for nutrient loading calculations ..................44

A1. Comparison of nutrient data collected and analyzed by the Reedy Creek Improvement Distrct and the U.S. 41 Geological Survey

\section{TABLES}

1. Drainage areas and periods of record for U.S. Geological Survey stations on Reedy Creek Improvement District area streams

2. Discharge statistics for Reedy Creek Improvement District area streams ............................................................

3. Wastewater inputs and discharges for north and south wetland areas and percolation pond system within the Reedy Creek Improvement District, central Florida, 1988-89.

4. Discharge statistics for Reedy Creek, August 1988 through December 1989........................................................... 18

5. Reaeration coefficient measurement data for Reedy Creek ..................................................................................25

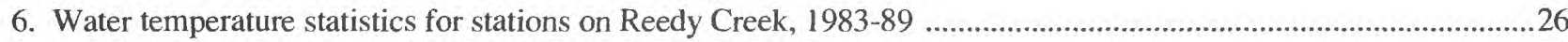

7. Specific conductance statistics for stations on Reedy Creek ...............................................................................27

8. Summary statistics of water-quality data for the Reedy Creek Improvement District, October 1985 through December 1989

9. Monthly summary of dissolved oxygen concentrations for station 02266300 , calendar years 1980 through $1989 \ldots . .31$

10. Summary of dissolved oxygen concentrations for stations 02236500 and 02266300 during common period of record, 1982-88

11. Summary of dissolved oxygen concentrations for stations on Reedy Creek, 1983-89.

12. Summary of nutrient and organic carbon concentrations in samples collected by the U.S. Geological Survey in the Reedy Creek Improvement District, October 1985 through December 1989

13. Equations selected for nutrient load estimate computations

14. Annual mean discharges into and out of the Reedy Creek Improvement District wetland conservation area, 1986-89

15. Computed annual loads of nitrogen species into and out of the Reedy Creek Improvement District wetland conservation area, 1986-89

16. Computed annual loads of total phosphorus, orthophosphate phosphorus, and organic carbon into and out of the Reedy Creek Improvement District wetland conservation area, 1986-89.

17. Summary of nutrient and organic carbon concentrations in samples collected in Reedy Creek by the Reedy Creek Improvement District, 1988-89

18. Total annual nutrient and organic carbon loadings from the north and south wetlands receiving wastewater effluent and at station $02266300,1988-89$

19. Nutrient and organic carbon loadings for stations on Reedy Creek, August 1988 through December 1989.

A1. Comparative statistics for U.S. Geological Survey and Reedy Creek Improvement District nutrient analytical results 


\begin{tabular}{rll}
\hline Multiply & By & To obtain \\
Length & & \\
inch (in.) & & millimeter \\
foot (ft) & 25.4 & meter \\
mile (mi) & 0.3048 & kilometer \\
Area & 1.609 & square kilometer \\
square mile $\left(\mathrm{mi}^{2}\right)$ & 2.590 & \\
$F l o w$ & & cubic meter per second \\
millimeter per year \\
cubic meter per second
\end{tabular}

Sea level: In this report, "sea level" refers to the National Geodetic Vertical Datum of 1929 (NGVD of 1929)--a geodetic datum derived from a general adjustment of the first-order level nets of the United States and Canada, formerly called Sea Level Datum of 1929.

Equations for temperature conversion between degrees Celsius $\left({ }^{\circ} \mathrm{C}\right)$ and degrees Fahrenheit $\left({ }^{\circ} \mathrm{F}\right)$ :

$$
\begin{aligned}
{ }^{\circ} \mathrm{C} & =5 / 9 \times\left({ }^{\circ} \mathrm{F}-32\right) \\
{ }^{\circ} \mathrm{F} & =\left(1.8^{\circ} \mathrm{C}\right)+32
\end{aligned}
$$

Transmissivity: In this report, transmissivity will be shown in feet squared per day $\left(\mathrm{ft}^{2} / \mathrm{d}\right)$ rather than in standard unit cubic foot per day per square foot times foot of aquifer thickness.

\author{
Abbreviated water-quality units \\ Pt-Co units = Platinum-Cobalt units \\ $\mu \mathrm{g} / \mathrm{L}=$ micrograms per liter \\ $\mu \mathrm{S} / \mathrm{cm}$ at $25^{\circ} \mathrm{C}=$ microsiemens per centimeter at $25^{\circ} \mathrm{C}$ \\ $\mathrm{mg} / \mathrm{L}=$ milligrams per liter \\ Acronyms \\ CRI $=$ Constant-rate injection \\ FDER = Florida Department of \\ Environmental Regulation
}




\title{
Hydrology and Water Quality of Reedy Creek in the Reedy Creek Improvement District, Central Florida, 1986-89
}

\author{
By Paul S. Hampson
}

\section{Abstract}

The hydrology and water quality of Reedy Creek within the Reedy Creek Improvement District in central Florida was investigated from 1986-89. The District operates a wastewatertreatment plant that discharges through two forested wetland areas and a percolation-pond system into Reedy Creek. Discharges from these wetland systems provide a relatively steady base flow which maintains streamflow in Reedy Creek during periods of low rainfall. Streamflows during the study were characterized by relatively long periods of below average discharge interspersed with periods of high discharges. The highest mean discharges were recorded in 1988 and the lowest mean discharges were recorded in 1989.

Water-quality data collection included the operation of four continuous water-quality monitors recording hourly water temperature, specific conductance, and dissolved oxygen concentration, and the collection of water-quality samples.

Dissolved oxygen concentrations were similar for all stations on Reedy Creek and frequently were less than the minimum Florida standard of 5.0 milligrams per liter. The lowest mean daily dissolved oxygen concentrations generally were recorded upstream from the wastewater discharges. The low dissolved oxygen concentrations recorded in Reedy Creek were similar to concentrations recorded in Big Creek, which drains an undeveloped area west of the Reedy Creek Improvement District. These low dissolved oxygen concentrations probably are the result of natural conditions.

Nutrient analyses of water-quality samples were used to compute loadings into and out of a wetland conservation area in the southern part of the District and in the reach of Reedy Creek down- stream from the wastewater discharges. Overall retention percentages for 1986-89, not including atmospheric and precipitation inputs, were 59.1 percent for total ammonia nitrogen; 3.4 percent for total organic nitrogen, which was the predominant nitrogen species; 33.2 percent for total nitrate nitrogen; 27.0 percent for total phosphorus; and 26.0 percent for total organic carbon. Retention percentages for total ammonia nitrogen and total organic carbon were significantly greater for the relatively wetter years of 1987 and 1988 than for the drier years of 1986 and 1989. The opposite pattern was observed for other nutrient species. Highest loading inputs to the wetland conservation area were from the reach of Reedy Creek receiving wastewater discharge. Discharges from the wetlands receiving wastewater and entering the wetland conservation area during 1988 and 1989 , respectively, carried 16.3 and 22.0 percent of the total nitrogen load, and 25.0 and 21.0 percent of the total phosphorus load.

\section{INTRODUCTION}

The Reedy Creek Improvement District (RCID) encompasses an area of about $43 \mathrm{mi}^{2}$ in southwestern Orange and northwestern Osceola Counties in central Florida (fig. 1). The area originally consisted largely of uninhabited swampland and scrubby flatland, but much has been converted to urbanized recreational and commercial use with the construction of the Walt Disney World complex. Development of the area has continued since the opening of the Magic Kingdom theme park in 1971, with the addition of the EPCOT Center park in 1981 and a variety of other attractions and lodging facilities between 1981 and 1989. Construction and operation of these facilities have altered the natural drainage systems, increased demands for potable water, and increased needs for wastewater treatment and disposal. 


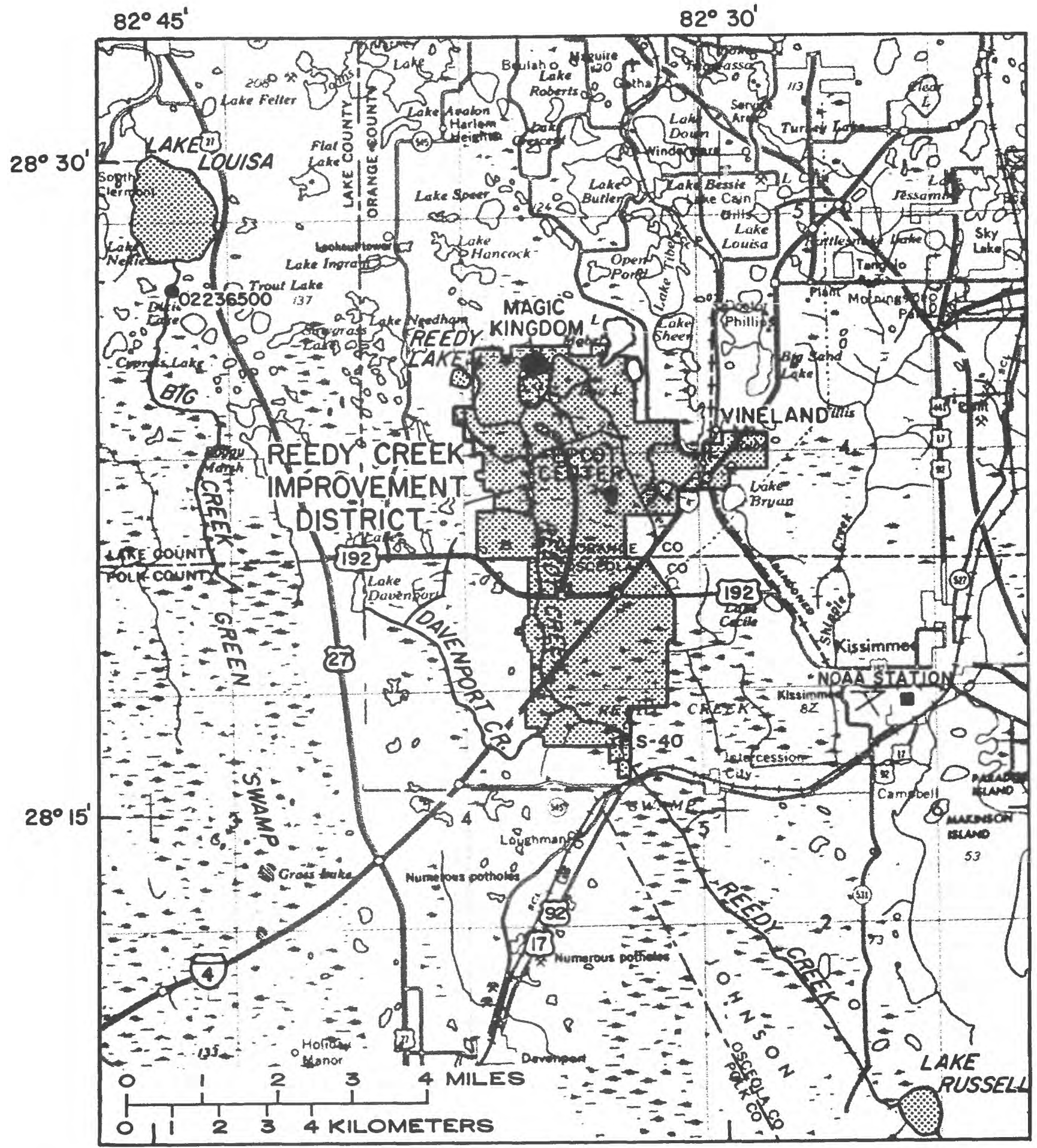

Figure 1. Location of study area. 
The RCID maintains and operates a secondary wastewater treatment plant within the District (fig. 2). Part of the treated wastewater is used for irrigation of ornamental plant stocks and the remainder is discharged through oxidation and infiltration ponds and through enclosed wetlands to Reedy Creek. Wastewater-treatment capacities have increased commensurate with development from about 3 to $4 \mathrm{Mgal} / \mathrm{d}$ in 1979 to about 7 to $8 \mathrm{Mgal} / \mathrm{d}$ in 1989. Associated discharges to Reedy Creek from the enclosed wetlands receiving treatment plant effluent have also increased from about $2.5 \mathrm{Mgal} / \mathrm{d}$ in 1979 to more than $4 \mathrm{Mgal} / \mathrm{d}$ in 1989. The RCID plans to decrease discharges to Reedy Creek and reduces the reliance on disposal to surface-water odies through the operation of a complex of rapid infiltration basins scheduled to start in 1990 .

Total phosphorus concentrations in Reedy Creek downstream from the wastewater discharge point are relatively high, sometimes exceeding $1.0 \mathrm{mg} / \mathrm{L}$, and dissolved oxygen concentrations are typically low. At times, dissolved oxygen concentrations decline to levels much lower than the $5.0 \mathrm{mg} / \mathrm{L}$ minimum standard set by the Florida Department of Environmental Regulation (FDER) (1983). The low dissolved oxygen concentrations probably result from natural runoff and ground-water inflow from wetlands adjacent to Reedy Creek, but the relative effects of natural runoff and wastewater discharges are unknown. Little is known about the processes controlling nutrient and dissolved oxygen concentrations in wetland streams such as Reedy Creek.

The U.S. Geological Survey (USGS), in cooperation with the RCID, studied the hydrology and water quality of Reedy Creek from October 1985 through September 1990. The study was conducted to provide a better understanding of processes affecting nutrient and dissolved oxygen concentrations and loadings to Reedy Creek, to evaluate the role of wetlands adjacent to Reedy Creek in streamflow and water quality, and to update past studies of the area.

\section{Purpose and Scope}

This report provides a description of the hydrology and water quality of Reedy Creek based on data collected during calendar years 1986 through 1989. Water-quality data collected during this study and traveltime-reaeration coefficient measurements made to evaluate the ability of Reedy Creek to assimilate oxygen-demanding materials are presented in this report. Results of long-term water-quality monitoring at stations on Reedy Creek are presented. Also included in this report are nutrient loads into and out of the wetlands adjacent to Reedy Creek, loads associated with wastewater discharge to Reedy Creek, and the effects of these loads on water quality.

Hydrologic conditions in the RCID and the effects of development were first described by Putnam (1975) for the period 1966 to 1973. A study by German (1986) updated much of the material presented in the earlier report through 1980 and presented additional water-quality information. This report updates much of the material presented in these earlier reports but focuses more closely on Reedy Creek.

\section{Description of the Study Area}

The RCID is contained within the Reedy Creek drainage basin, which has headwaters northwest of the RCID near Reedy Lake (fig. 2). About $44 \mathrm{mi}^{2}$ of the Reedy Creek basin lies northwest of the RCID. Reedy Creek flows south-southeast through the RCID and empties into Lake Russell (fig. 1) which drains to the Kissimmee River farther south. The major tributaries to Reedy Creek are Whittenhorse Creek, Davenport Creek, and Bonnet Creek. Cypress Creek is tributary to Bonnet Creek (fig. 2). Drainage areas and the periods of record for these streams are given in table 1.

Drainage in the Reedy Creek basin and the RCID generally is poor. The basin is characterized by low, undulating hills and wide, swampy valleys with numerous lakes of various sizes. A large part of the basin is covered by forested wetlands in which the water table is above or near land surface for a substantial part of the year. Heavy rainfall often fills the surficial aquifer to land surface in these areas and water sometimes stands over large parts of the RCID for extended periods of time. The many lakes and swampy areas provide a relatively large surface storage capacity which retards drainage and results in relatively slow runoff rates.

Drainage patterns within the RCID have been greatly altered since development began in 1967. Canals, dikes, and automatic flow-control structures have replaced the previously ill-defined, swampy streams and valleys. The canal system consists of about $44 \mathrm{mi}$ of canals and $19 \mathrm{mi}$ of dikes constructed to control inflow to the RCID from upstream sources and 


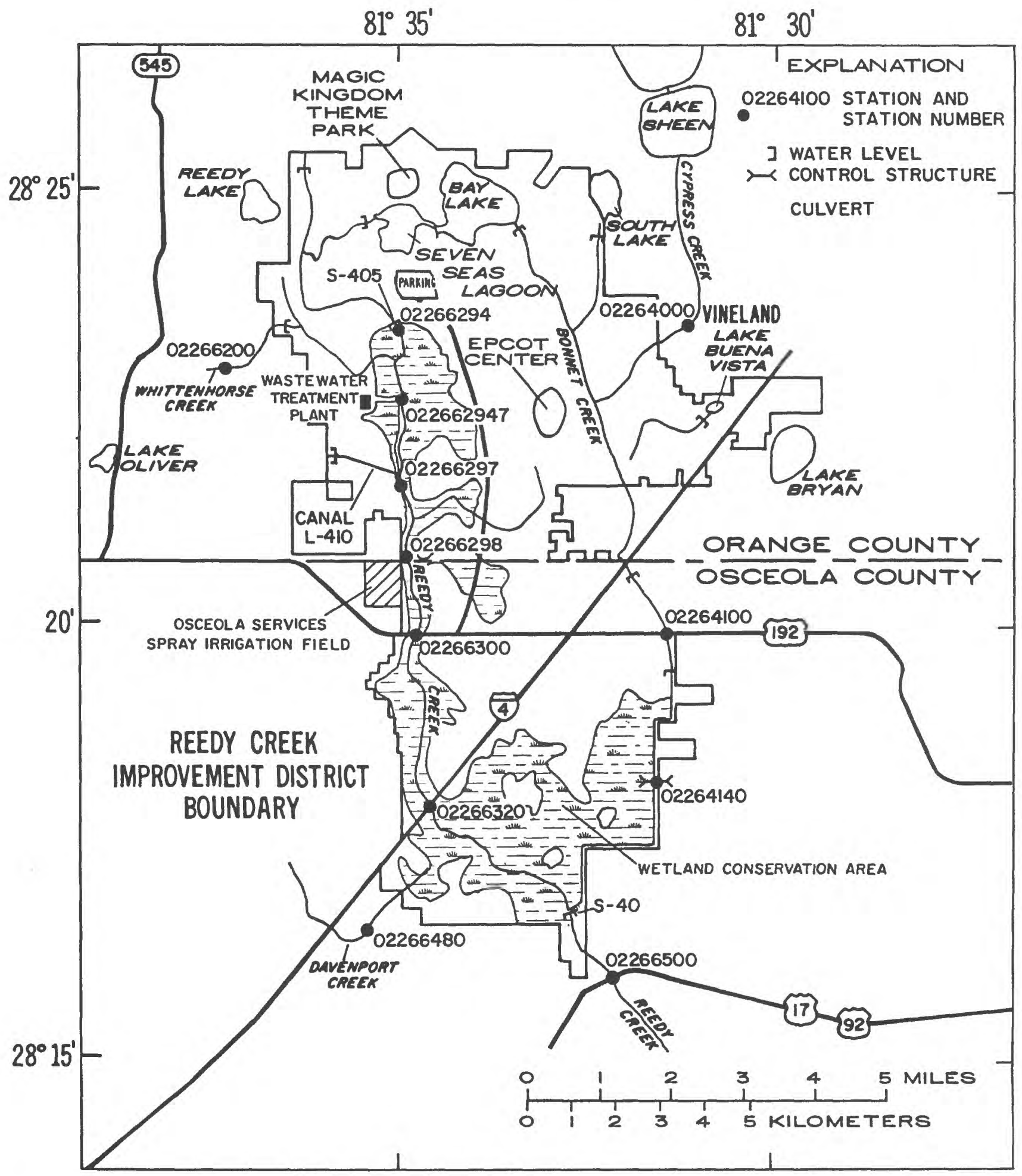

Figure 2. Station locations and hydraulic structures within the Reedy Creek Improvement District. 
control discharges out of the District. The canal system was designed to collect and route runoff sufficient to protect developed areas from floods with a recurrence interval of 50 years or less and to avoid excessive drainage of the surficial aquifer system and wetland areas during periods of drought.

Table 1. Drainage areas and periods of record for U.S. Geological Survey stations on Reedy Creek Improvement District area streams

\begin{tabular}{llcl}
\hline $\begin{array}{c}\text { Station } \\
\text { number }\end{array}$ & Station name & $\begin{array}{c}\text { Drainage } \\
\text { area } \\
\text { square } \\
\text { miles) }\end{array}$ & Period of record \\
\hline 02264000 & $\begin{array}{l}\text { Cypress Creek at } \\
\text { Vineland }\end{array}$ & 30.3 & $\begin{array}{l}44 \text { years, } \\
\text { Aug. 1945 to present }\end{array}$ \\
02266200 & $\begin{array}{l}\text { Whittenhorse } \\
\text { Creek near } \\
\text { Vineland }\end{array}$ & 12.4 & $\begin{array}{l}23 \text { years, } \\
\text { May } 1966 \text { to present }\end{array}$ \\
02266480 & $\begin{array}{l}\text { Davenport Creek } \\
\text { near Loughman }\end{array}$ & 23.0 & $\begin{array}{l}20 \text { years, } \\
\text { Jan. } 1969 \text { to present }\end{array}$ \\
02264100 & $\begin{array}{l}\text { Bonnet Creek } \\
\text { near Vineland }\end{array}$ & 56.1 & $\begin{array}{l}23 \text { years, } \\
\text { Jan. } 1969 \text { to present }\end{array}$ \\
02266300 & $\begin{array}{l}\text { Reedy Creek near } \\
\text { Vineland }\end{array}$ & 75.0 & $\begin{array}{l}23 \text { years, } \\
\text { May } 1966 \text { to present }\end{array}$ \\
02266500 & $\begin{array}{l}\text { Reedy Creek near } \\
\text { Loughman }\end{array}$ & 110.0 & $\begin{array}{l}\text { 41 years, } \\
\text { Oct. } 1939 \text { to Sept. } 1959, \\
\text { July } 1968 \text { to present }\end{array}$ \\
\hline
\end{tabular}

Three tributaries, Cypress, Whittenhorse, and Davenport Creeks, flow into the RCID. Cypress Creek originates at Lake Sheen (fig. 2), the southernmost lake in the Lake Butler chain of lakes (fig. 1), and flows south through a swampy valley ranging from 0.5 to $0.75 \mathrm{mi}$ in width, entering the RCID from the northeast. The Whittenhorse and Davenport Creek basins are similar, consisting principally of flat, swampy areas adjacent to areas of higher elevation which are or have been used for citrus production. Much of the citrus in the Whittenhorse Creek basin has not been replanted following killing freezes in December 1983, January 1985, January 1988, and December 1989. Whittenhorse Creek empties into a RCID canal along the northwest RCID boundary and discharges through flow-control structures into Reedy Creek. Davenport Creek empties into the wetland conservation area adjacent to Reedy Creek in the southwestern part of the RCID (fig. 2).

The Bonnet Creek basin includes the Cypress Creek basin and an additional $25.8 \mathrm{mi}^{2}$ within the RCID. Bonnet Creek has been extensively modified with numerous canals providing drainage for shopping and hotel complexes at Lake Buena Vista (fig. 2). Outflows from Seven Seas Lagoon, Bay Lake, and South Lake are also routed into Bonnet Creek. The creek has been extensively channelized and altered with the installation of numerous flow-control structures. These gated structures retain water in the channelized reaches and avoid dewatering of adjacent wetland and developed areas. Bonnet Creek flows into the wetland conservation area south of U.S. Highway 192. Discharge from most of this wetland conservation area is routed into Reedy Creek and leaves the RCID through structure S-40 at the southernmost boundary of the RCID. Some discharge from Bonnet Creek is routed eastward through manually controlled culverts at station 02264140 (fig. 2). These culverts are adjusted to maintain water levels in the wetlands area favorable to the natural vegetation and to restore the eastward flow that existed prior to development.

The main stem of Reedy Creek originates in the wetlands northwest of the RCID near Reedy Lake (fig. 2). The stream follows its original course from the headwaters to the RCID boundary where it empties into the RCID boundary canal system. Within the upper part of the RCID, the stream channel has been extensively altered by the construction of drainage canals and gated flow-control structures. Runoff from the Magic Kingdom theme park, parking lots, and associated hotel facilities is routed into the canal system (Reedy Creek) about 0.3 mi north of structure S-405 (station 02266294) after passing through a system of canals and detention ponds. Canal L-410 joins the main stem of Reedy Creek just upstream from station 02266297 and receives most of the drainage from Whittenhorse Creek and the northwestern part of the RCID through the RCID boundary canal system. Discharge from wetlands receiving effluent from the wastewater-treatment plant enters the creek at points just downstream from station 02266294, near the confluence of canal L-410 with the main stem, and just downstream from station 02266297. Between stations 02266297 and 02266298 , the creek channel is ill-defined with flow following numerous small channels through a forested wetland area. From station 02266298 to structure S-40 at the RCID southern boundary, the stream follows the original natural channel which has occasionally been cleared and snagged to remove obstructions. The Osceola Services spray irrigation field, which receives approximately $1 \mathrm{Mgal} / \mathrm{d}$ of wastewater, is located adjacent to Reedy Creek immediately downstream from station 02266298. 


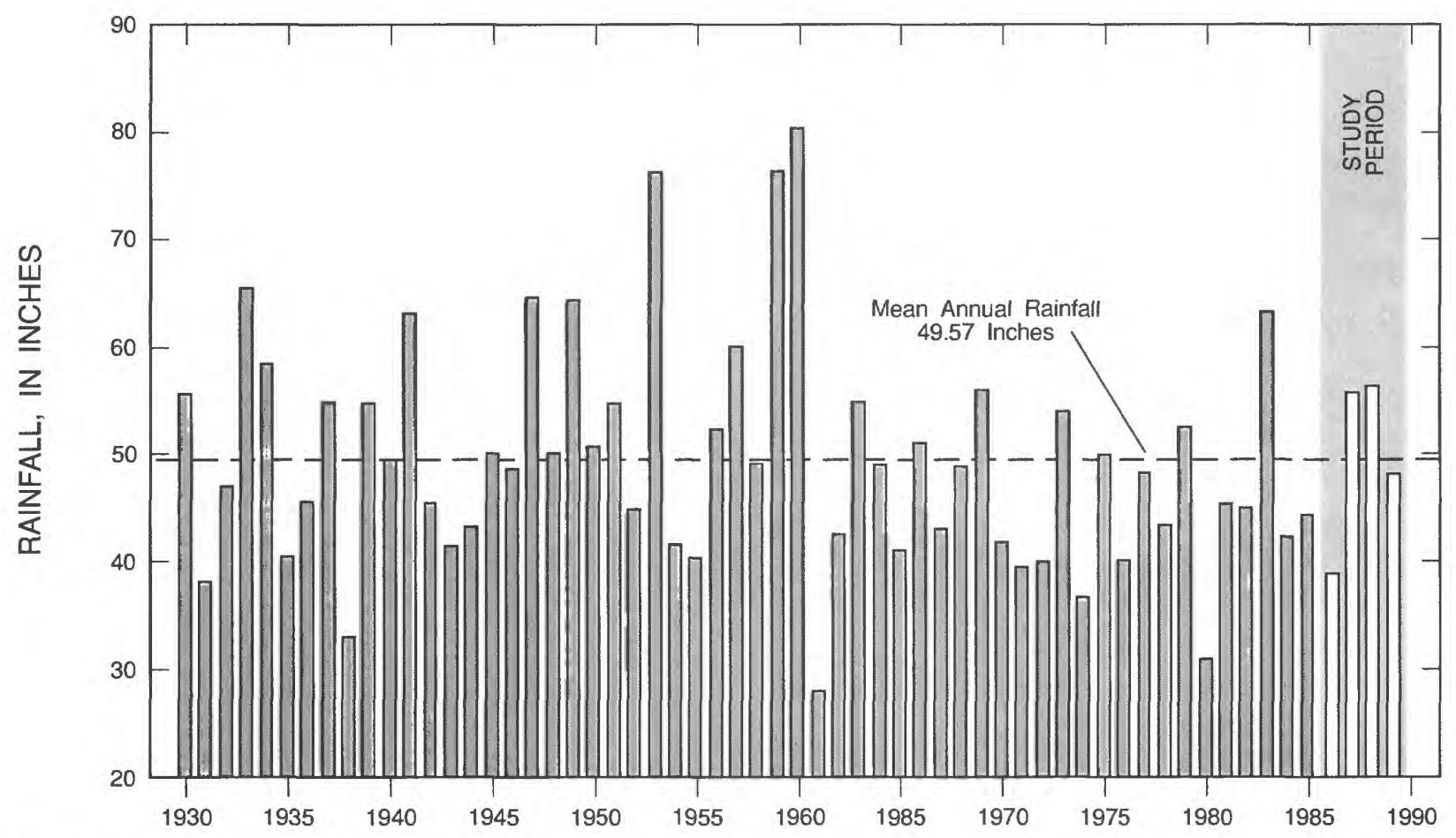

Figure 3. Annual rainfall at the National Oceanic and Atmospheric Administration station at Kissimmee, $1930-89$.

Discharge leaving the RCID through structure S-40 follows the original natural channel south to Lake Russell which is connected to the Kissimmee River. Most of the surface drainage from the RCID is routed through structure $S-40$, including discharge from the watersheds of Bonnet, Cypress, Davenport, and Whittenhorse Creeks.

\section{HYDROLOGIC CONDITIONS}

Hydrologic conditions were assessed by comparing rainfall and streamflow records collected during the study period with long-term records for rainfall and streamflow stations in and near the Reedy Creek Improvement District. Rainfall amounts recorded during the study at one station were compared with a 59year period of record. Streamflow records for six stations with periods of record ranging from 20 to 44 years were examined.

\section{Rainfall}

Total annual rainfall for the National Oceanic and Atmospheric Administration (NOAA) station at Kissimmee, Fla. (fig. 1) 1930 through 1989 is shown in figure 3 (National Oceanic and Atmospheric Administration, 1930-1989). The long-term mean annual rainfall is $49.57 \mathrm{in}$. During the period of record, annual rainfall has ranged from 28.07 in. in 1961 to 80.03 in. in 1960, the year of Hurricane Donna. Annual rainfall for the study period 1986-89 (shown in fig. 3 by the hachured pattern) averaged $49.85 \mathrm{in} / \mathrm{yr}$, very near the long-term mean. Individual yearly totals are 38.94 in. for $1986,55.83 \mathrm{in}$. for $1987,56.42 \mathrm{in}$. for 1988 , and $48.22 \mathrm{in}$. for 1989 .

The average annual rainfall for 1986-89 is similar to the mean annual rainfall for the period of record, but 1986-89 is characterized by long periods of below average precipitation punctuated by extreme rainfall events. The long-term mean monthly rainfall and deviations from the mean monthly rainfall for $1986-89$ are shown in figure 4. Rainfall in most of Florida generally follows the seasonal pattern shown in figure $4 \mathrm{~A}$ with a wet season normally occurring during the summer and early autumn months of June through September and a relatively dry season normally occurring from November through January. Most precipitation during the wet season is associated with intense thunderstorms common across peninsular Florida during the warm, summer months. Rainfall during the dry season generally is associated with the movement of weather fronts across 
the State. The frontal movements generally result in less intense rainfall events of longer duration and deliver less net precipitation than thunderstorms.

Rainfall during most of 1986 through 1989 was below long-term means (fig. 4B), with the exception of a few months with much greater than mean monthly totals. The higher than average totals for the months of March and November 1987, as well as for November 1988, were the result of relatively short-term extreme rainfall events. Between March 23 and April 1, 1987, approximately 8 in. of rainfall in the study area resulted in record-high discharges at several discharge stations in the area. Other extreme events were approximately 6 in. of rainfall on November 3, 1987, and more than 7 in. on November 22-23, 1988. The higher than average monthly rainfall for July and August 1988 resulted from a large number of 1 to 2 in. rainfall events during these months.

\section{Streamflow}

Streamflows during the study period generally reflected the rainfall pattern, with long periods of below average discharge interspersed with brief periods of above average discharges. Annual discharges during water years 1967 through 1989 for the three tributary streams flowing into the RCID are shown in figure 5. Water years begin in October and end in September; for example, water year 1967 refers to the period from October 1966 to September 1967. Streamflow statistics and extremes are given in table 2. All discharges listed for USGS stations were determined by methods described by Rantz and others (1982).

Cypress, Whittenhorse, and Davenport Creeks generally have similar streamflow characteristics (German, 1986) as indicated by the annual discharges in figure 5. The long-term mean discharge shown for
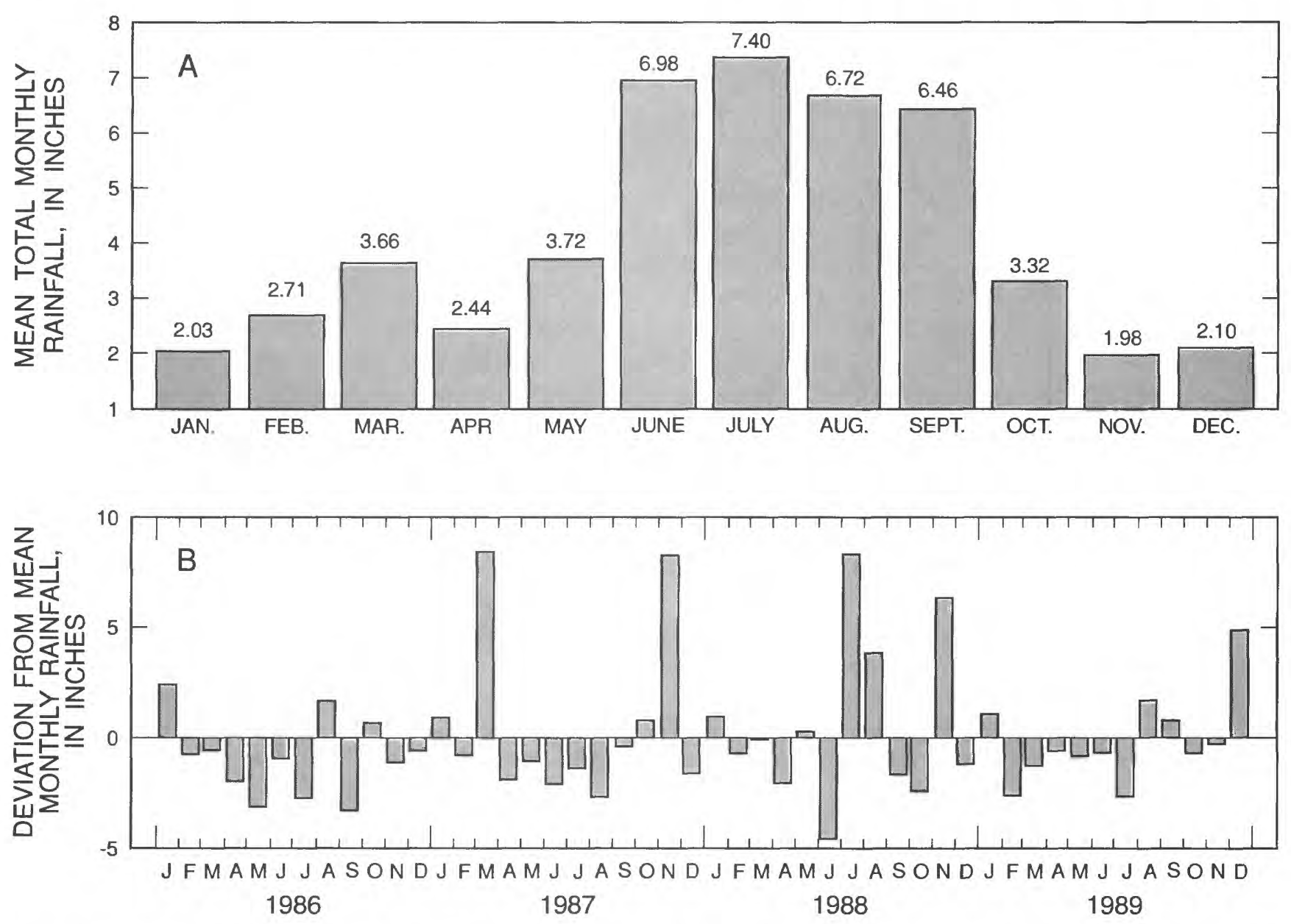

Figure 4. (A) Mean monthly rainfall and (B) deviations from the mean monthly rainfall, 1986-89, at the National Oceanic and Atmospheric Administration station at Kissimmee. 
Cypress Creek, however, is more representative of the period 1945-67 than for the period of record shown in figure 5. For water years 1967-89, the mean daily discharge is $2.39 \mathrm{ft}^{3} / \mathrm{s}$ as compared to the $5.68 \mathrm{ft}^{3} / \mathrm{s}$ mean for the entire period of record. The decreased discharge probably is the result of changes in the upper part of the drainage basin and decreased outflow from the Lake Butler chain of lakes that form the headwaters of Cypress Creek. Davenport Creek differs from the other two tributaries in that it has a higher base flow during dry periods. Whittenhorse and Cypress Creeks often remain dry for extended periods. The higher base flow in the Davenport Creek basin probably reflects greater availability of ground- and surface-water storage and perhaps upward leakage from the underlying Floridan aquifer system (German, 1986).

Annual mean discharges for Davenport and Whittenhorse Creeks during 1986-89 were near or above the long-term mean, with the highest annual mean discharge for both stations recorded in water year 1988 (fig. 5). Annual mean discharge for Cypress Creek exceeded the long-term mean during the study period only for water year 1988. The annual mean discharges for Cypress Creek during water years 1986-89 were, however, similar to or greater than the mean for the period 1967-89. Means for the 1986-89 water years slightly exceeded the means for the periods of record at all three stations as listed in table 2.

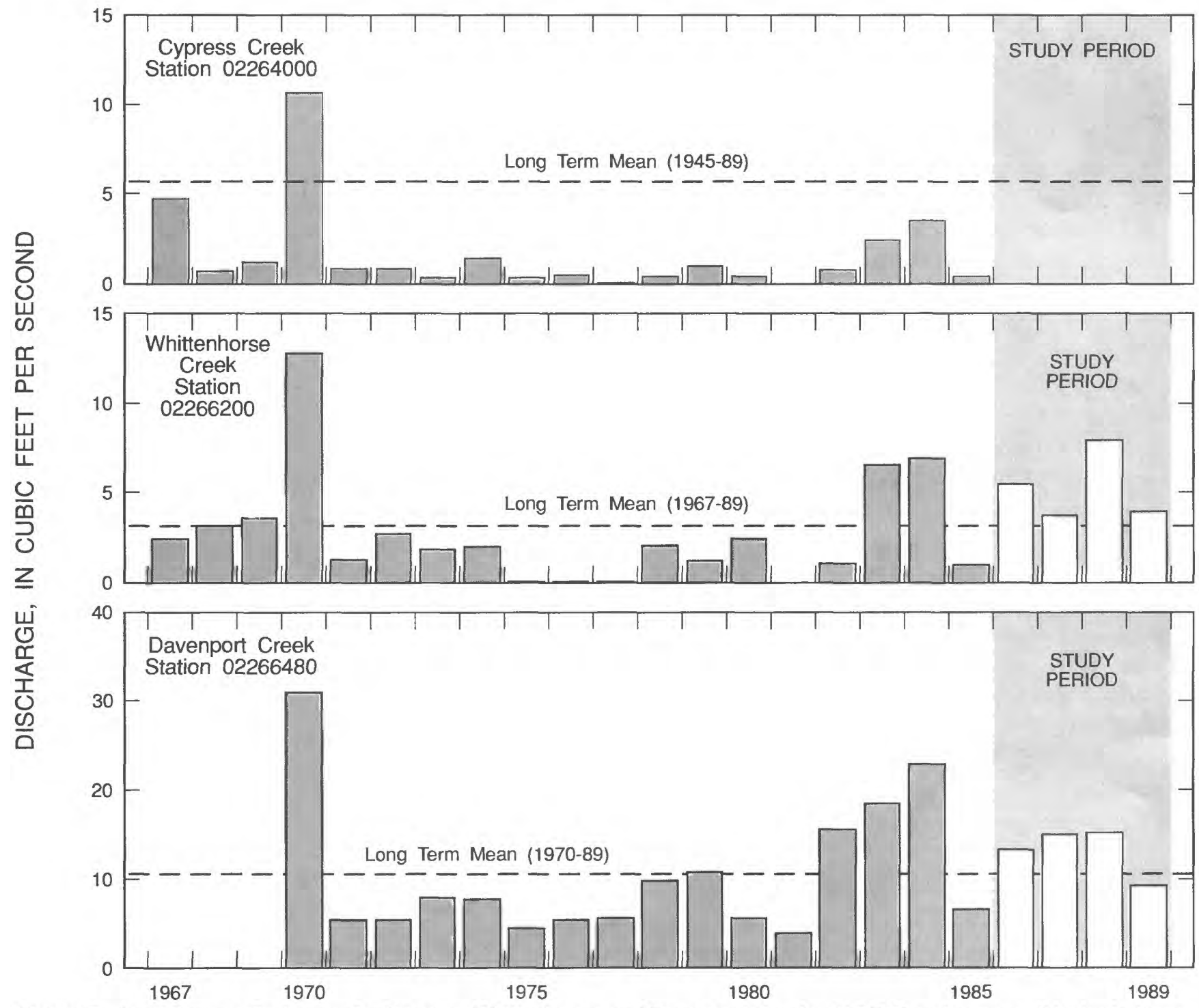

Figure 5. Annual mean discharges for Cypress, Whittenhorse, and Davenport Creeks, 1967-89 water years. (Unshaded bars represent study period.) 
Table 2. Discharge statistics for Reedy Creek Improvement District area streams

[All discharges are in cubic feet per second. Zero discharges have occurred several times. Date of occurrence is listed below extreme discharge value. Low and high discharges are instantaneous values]

\begin{tabular}{|c|c|c|c|c|c|c|c|}
\hline \multirow{2}{*}{$\begin{array}{l}\text { Station } \\
\text { number }\end{array}$} & \multirow{2}{*}{ Station name } & \multicolumn{3}{|c|}{$\begin{array}{l}\text { Discharge during } \\
\text { period of record }\end{array}$} & \multicolumn{3}{|c|}{$\begin{array}{l}\text { Discharge during } \\
\text { 1986-89 water years }\end{array}$} \\
\hline & & Low & Mean & High & Low & Mean & High \\
\hline 02264000 & Cypress Creek at Vineland & 0.0 & 5.68 & $\begin{array}{c}309 \\
9-11-60\end{array}$ & 0.0 & 5.92 & $\begin{array}{c}70 \\
3-31-87\end{array}$ \\
\hline 02266200 & Whittenhorse Creek near Vineland & 0.0 & 3.18 & $\begin{array}{c}62 \\
3-31-87\end{array}$ & 0.0 & 5.31 & $\begin{array}{c}62 \\
3-31-87\end{array}$ \\
\hline 02266480 & Davenport Creek near Loughman & $\begin{array}{c}0.32 \\
5-16-81\end{array}$ & 10.7 & $\begin{array}{c}498 \\
9-22-69\end{array}$ & $\begin{array}{c}0.95 \\
6-20-89\end{array}$ & 11.5 & $\begin{array}{c}136 \\
11-24-88\end{array}$ \\
\hline 02264100 & Bonnet Creek near Vineland & 0.0 & 22.8 & $\begin{array}{c}1,230 \\
11-04-87\end{array}$ & 0.0 & 24.0 & $\begin{array}{c}1,230 \\
11-23-88\end{array}$ \\
\hline 02266300 & Reedy Creek near Vineland & 0.0 & 34.2 & $\begin{array}{c}1,910 \\
9-11-60\end{array}$ & $\begin{array}{c}6.5 \\
6-25-89\end{array}$ & 48.8 & $\begin{array}{c}1,710 \\
11-23-88\end{array}$ \\
\hline 02266500 & Reedy Creek near Loughman & 0.0 & 66.2 & $\begin{array}{c}790 \\
9-24-69\end{array}$ & 0.0 & 55.8 & $\begin{array}{c}779 \\
4-02-87\end{array}$ \\
\hline
\end{tabular}

The mean annual discharges for water years 1986-89 are not fully representative of hydrologic conditions for that period of time. During most of the study period, streamflows were below average. However, this period also included a number of short-duration, highdischarge events. Graphs of daily mean discharges (fig. 6) for Cypress, Whittenhorse, and Davenport Creeks illustrate discharge extremes that correlate with periods of much greater than average rainfall shown in figure 4 . The highest daily mean discharges at Cypress and Whittenhorse Creeks during calendar years 1986-89 were during the event of late March 1987 which set a new high discharge of $62 \mathrm{ft}^{3} / \mathrm{s}$ for the period of record at Whittenhorse Creek. The highest daily mean discharge during 1986-89 at Davenport Creek was $133 \mathrm{ft}^{3} / \mathrm{s}$ recorded during late November 1988 . Both of these discharge events had a recurrence interval of 25 years. In figure 6, the periods of high discharge in Cypress and Whittenhorse Creeks are separated by several relatively long periods of zero flow. The longest zerodischarge periods during 1986-89 were from May through December 1989 at Cypress Creek and from April through mid-September 1989 at Whittenhorse Creek. Davenport Creek had several periods of low flow, but no periods of zero flow during 1986-89.

Annual discharges at stations on Bonnet and Reedy Creeks follow a pattern similar to that of discharges of the three tributary streams (fig. 7). With the exception of Reedy Creek near Loughman, annual discharges for water years 1986-89 were near or above long-term averages. The drainage basin upstream from station 02266500, Reedy Creek near Loughman, has been greatly altered since the record began in October 1939 and, as in the previously discussed case of Cypress Creek, the long-term mean is more representative of the period 1939-59 than of the period shown in figure 7. The net effect of development on discharge at the Loughman station has been to decrease streamflow. The highest annual discharges for all three stations during water years 1986-89 were in water year 1988 (as with the tributary streams); the lowest annual discharges were recorded in water year 1989, except at Reedy Creek near Vineland where the 1987 discharge was slightly lower than the 1989 discharge (fig. 7).

Comparison of the annual mean discharges shown in figure 7 with the respective long-term mean discharges indicates the effects of increased wastewater discharges upstream from station 02266300 , Reedy Creek near Vineland. Discharges for the Vineland station exceeded the long-term mean by a greater amount than discharges at the other two stations from approximately water year 1983 to present. The increased base flow at the Vineland station is also indicated by the flow-duration curves of daily mean discharge at Bonnet, Davenport, Reedy, and Whittenhorse Creeks for the period of record and the study period, water years 1986-89 (fig. 8). The flow-duration curves show the percentage of daily mean discharges that exceed a given discharge value. The graphs show that discharge distributions during water years $1986-89$ for 
Davenport and Bonnet Creeks were very similar to the distribution for the entire period of record at these stations, with low discharges somewhat less frequent for Davenport Creek and somewhat more frequent for Bonnet Creek. The divergence of the two curves for Whittenhorse Creek reflects the long periods of low or zero flow during water years 1986-89. Only data from station 02266300, Reedy Creek near Vineland, shows a marked increase in base flow during water years 1986-89 as compared to the period of record, reflecting maintenance of streamflow by the wastewater discharge during very dry periods.
Streamflow records for Bonnet and Reedy Creeks during calendar years 1986-89 were characterized by relatively long periods of below average discharge interspersed with brief periods of high discharge as shown by the daily mean discharges plotted in figure 9 . As with tributary streamflow, highest discharges correlate with higher-than-average rainfall periods. The highest discharges at stations 02264100 (Bonnet Creek) and 02266300 (Reedy Creek near Vineland) during 1986-89 were the result of the early November 1987 rainfall event. A record high daily mean discharge of $610 \mathrm{ft}^{3} / \mathrm{s}$ occurred on November 4, 1987, at station

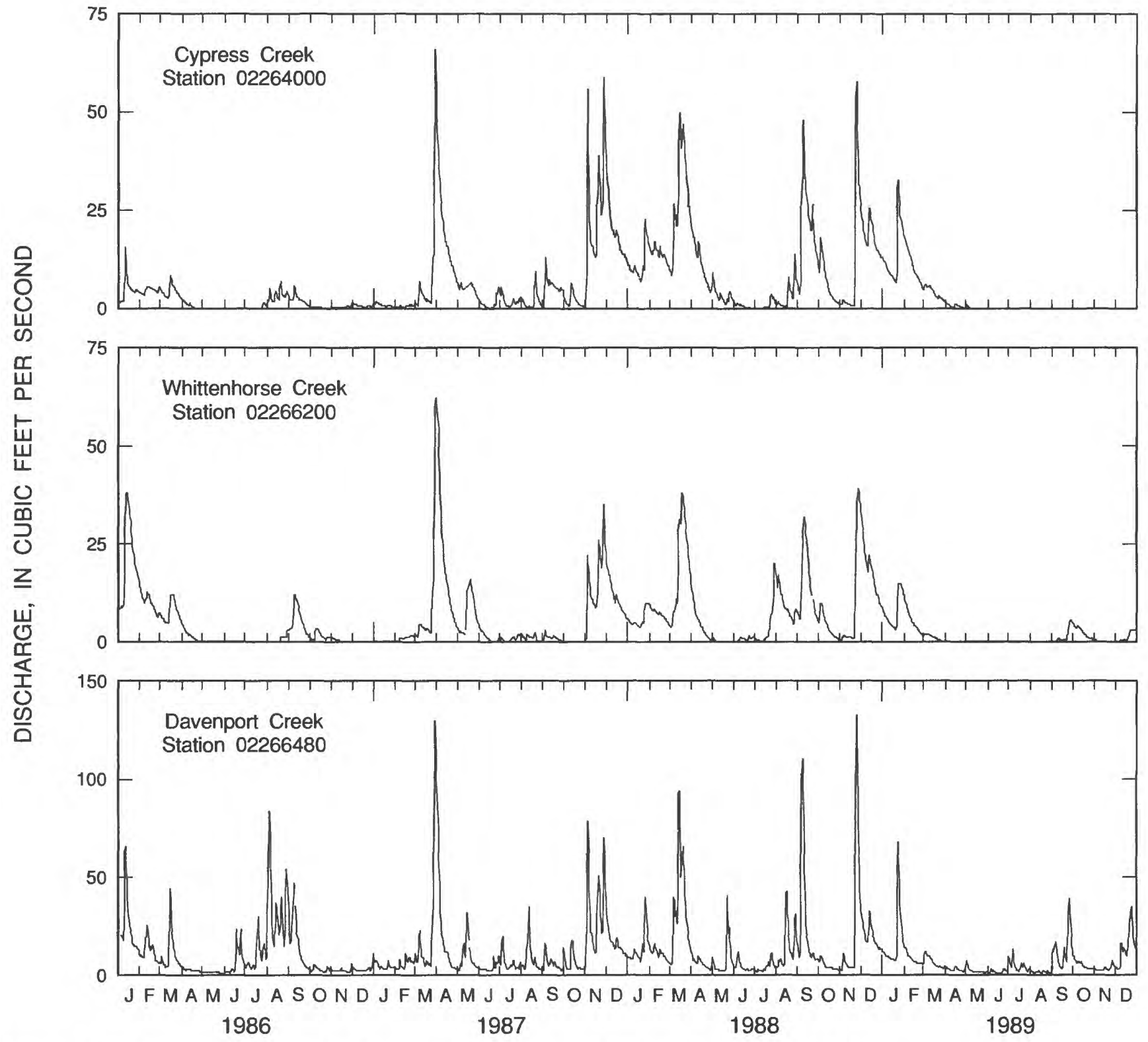

Figure 6. Daily mean discharges for Cypress, Whittenhorse, and Davenport Creeks, 1986-89. 


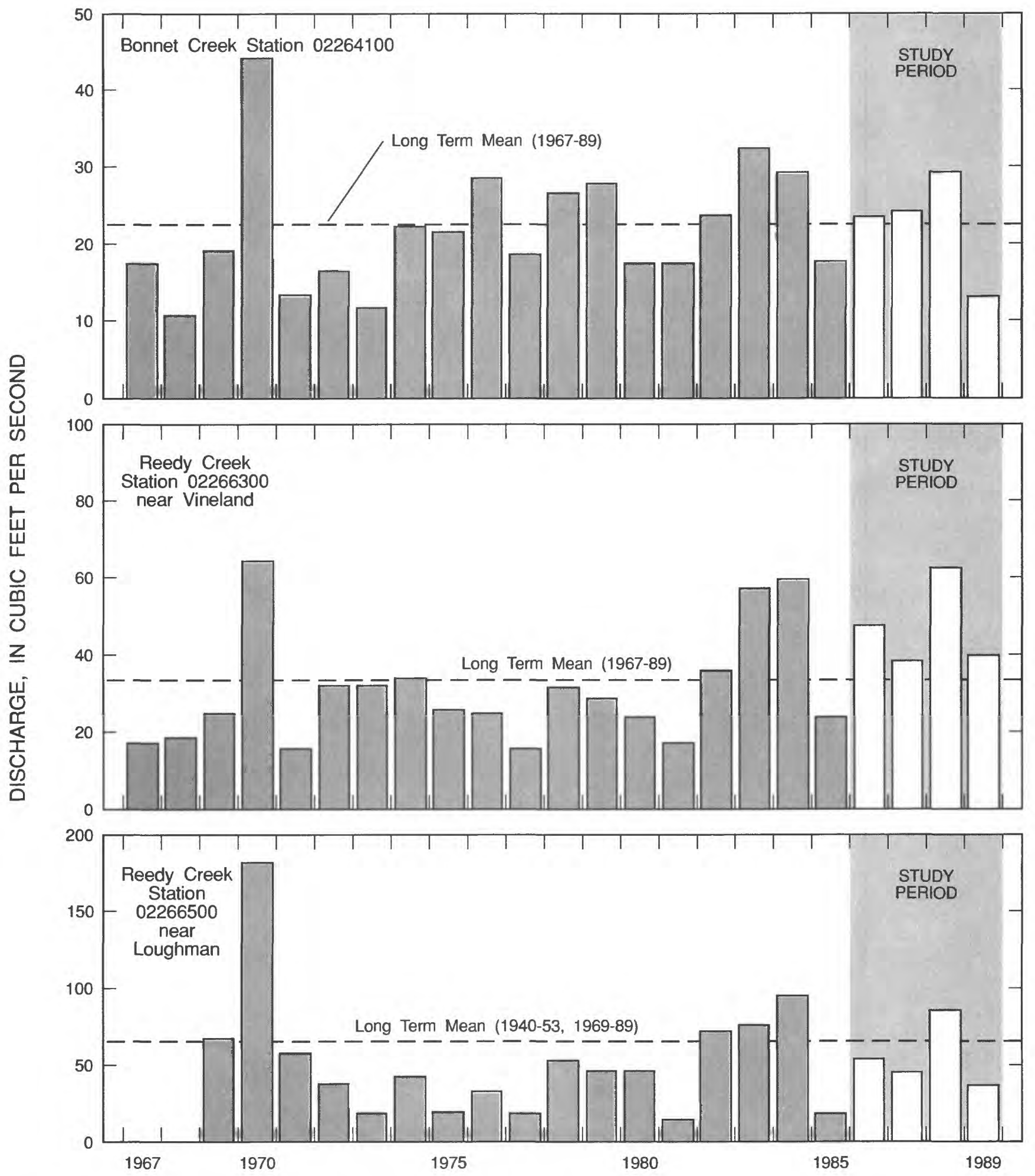

Figure 7. Annual mean discharges for Bonnet and Reedy Creeks, 1967-89. 

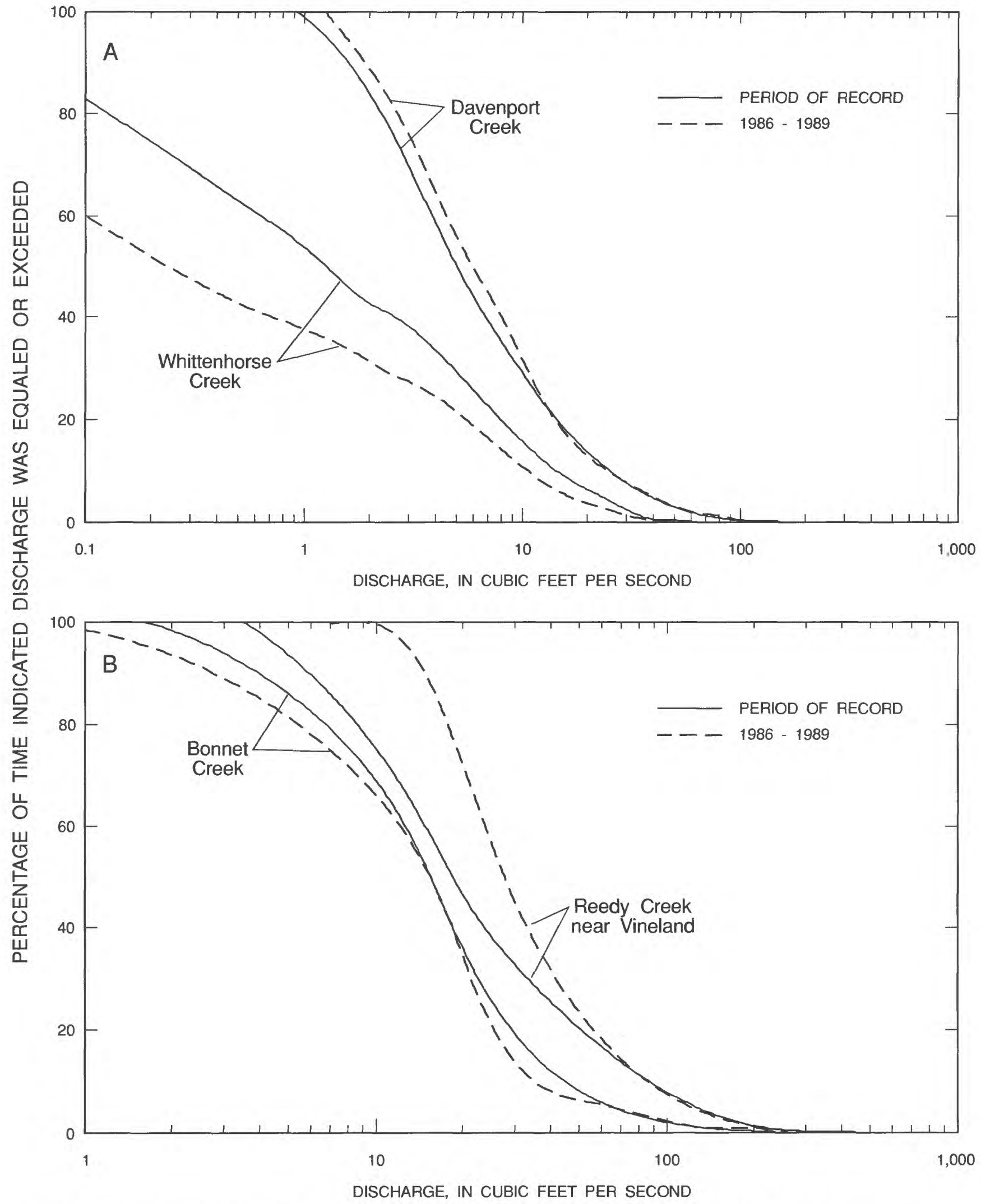

Figure 8. Flow-duration curves for (A) Whittenhorse and Davenport Creeks, and (B) Bonnet and Reedy Creeks. 


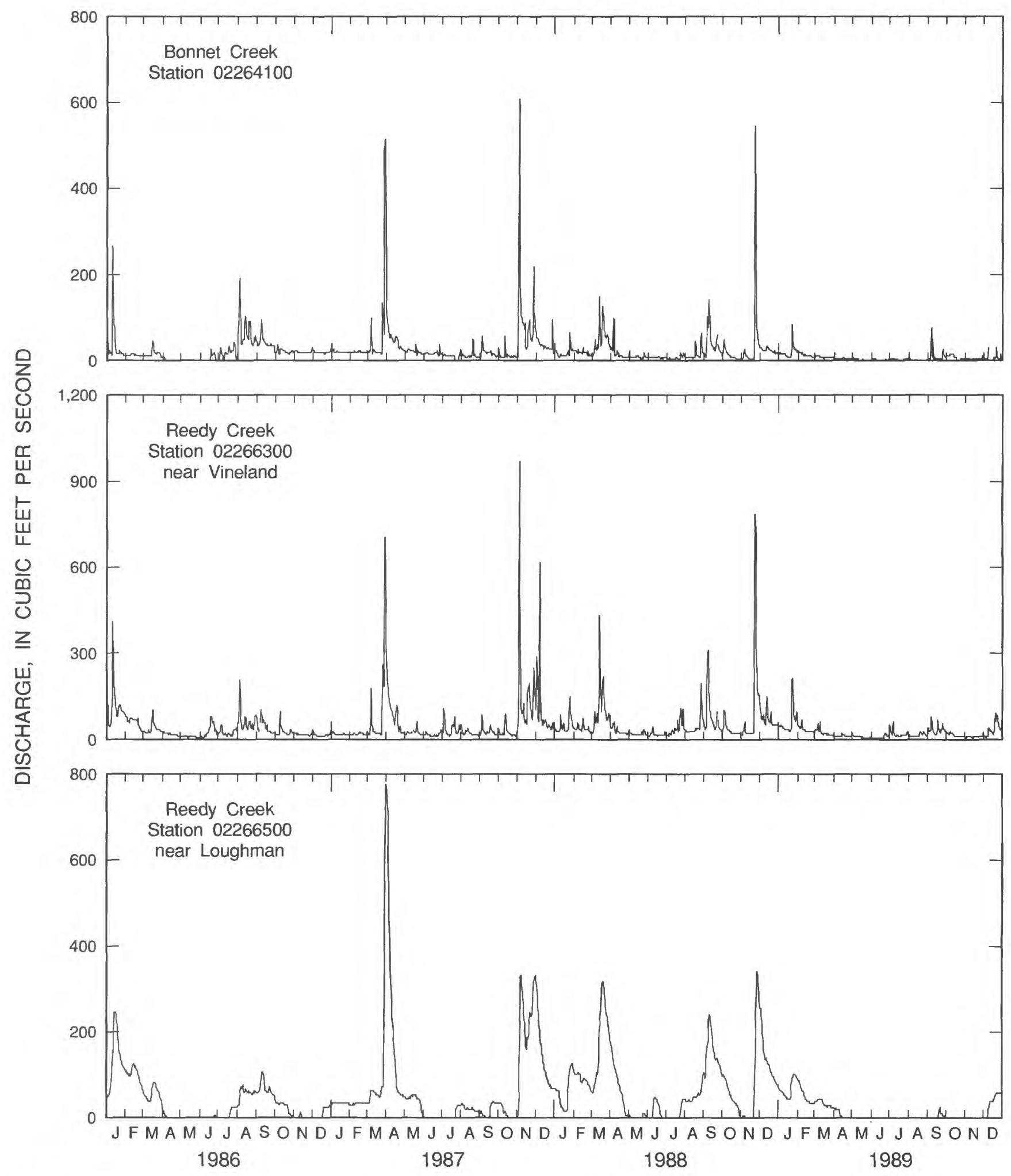

Figure 9. Daily mean discharges at stations on Bonnet and Reedy Creeks, 1986-89. 
02264100 on Bonnet Creek. A near-record high discharge for station 02266500 (Reedy Creek near Loughman) occurred on April 2, 1987. There were relatively long periods of zero flow at two stations during 198689 , the longest of which were from mid-May through mid-June 1986 at station 02264100 on Bonnet Creek and from May through mid-September 1989 at station 0226500 (Reedy Creek near Loughman). Station 02266300 (Reedy Creek near Vineland) had no zero discharge days during the study period.

\section{WASTEWATER DISCHARGES}

Wastewater from the RCID sewage-treatment plant discharges into two forested wetland areas (a north area and a south area) and into a percolation pond system (fig. 10) which empties into a nonforested wetland area adjacent to and east of the ponds through a system of underdrains. Water from the wetland areas enters the main stem of Reedy Creek through overflow weirs calibrated for discharge determination at three stations: RC23, which drains the north forested wetland; RC18, which drains the south forested wetland; and PP7, which drains the nonforested wetland area associated with the percolation ponds. Discharges at these stations and treatment plant inputs to the systems were furnished by the RCID. Discharges were measured by the USGS at station 022662947, downstream from RC23; station 02266210, on canal L-410; station 02266298 , immediately upstream from the Osceola Services spray irrigation field; and station 02266300, at U.S. Highway 192.

Approximately 80 percent of the wastewater discharged into Reedy Creek during this study was from the north and south wetland areas. Discharges at station PP7 from the percolation pond system usually accounted for the remaining 20 percent. The north forested wetland and station RC23 were operational only from June 1988 through July 1989. From February 1989 through July 1989, discharge from RC23 was routed into the south wetland area (and through station $\mathrm{RC} 18$ ) rather than directly into Reedy Creek.

Monthly mean discharges for station $\mathrm{RC} 18$ are shown in figure 11 for calendar years 1979 through 1989 , along with monthly streamflow at station 02266300 . The RC18 discharges given for June 1988 through February 1989 also include RC23 discharges so the values represent total discharge from the forested wetland systems. Monthly mean discharges from the forested wetland areas ranged from $0.0 \mathrm{ft}^{3} / \mathrm{s}$ while the system was out of service in September 1981 and May 1982 to $12.2 \mathrm{ft}^{3} / \mathrm{s}$ in February 1989. The mean discharge from the wetland areas for calendar years 1979 through 1989 was $5.7 \mathrm{ft}^{3} / \mathrm{s}$. Monthly mean discharges of Reedy Creek near Vineland (station 02266300) during the same period ranged from $2.6 \mathrm{ft}^{3} / \mathrm{s}$ in May 1981 to $159 \mathrm{ft}^{3} / \mathrm{s}$ in November 1987, and averaged $40.3 \mathrm{ft}^{3} / \mathrm{s}$ for the entire period. On average, discharge from the north and south forested wetland areas accounted for about 14 percent of the discharge at the Vineland station for 1979 through 1989, and ranged from 0 to as much as 55 percent.

Daily treatment plant inputs and discharges for the forested wetland areas and the percolation pond system are available for calendar years 1988 and 1989. Means and ranges for the inputs to and discharges from the systems are given in table 3 . Total wastewater discharged from the treatment plant to the three systems in 1988-89 averaged $8.39 \mathrm{ft}^{3} / \mathrm{s}(5.42 \mathrm{Mgal} / \mathrm{d})$ and ranged from $4.03 \mathrm{ft}^{3} / \mathrm{s}$ to $12.23 \mathrm{ft}^{3} / \mathrm{s}$ (2.6-7.9 Mgal/d). Total discharge from the three systems over the same period averaged $9.05 \mathrm{ft}^{3} / \mathrm{s}(5.8 \mathrm{Mgal} / \mathrm{d})$ and ranged from 1.55 $\mathrm{ft}^{3} / \mathrm{s}$ to $33.03 \mathrm{ft}^{3} / \mathrm{s}(0.86-21.3 \mathrm{Mgal} / \mathrm{d})$.

The relative contributions from the three discharge points to the total discharges to Reedy Creek are indicated by the monthly discharges shown in figure 12 . The top figure shows the relative contribution from each of the stations RC23, RC18, and PP7 to the total discharge from the three stations to Reedy Creek (represented by the total height of the bar). Direct discharge to Reedy Creek through RC23 was discontinued in February 1989. Between February 1989 and July 1989, flow was routed from $\mathrm{RC} 23$ and the north forested wetland area into the south forested wetland area and into Reedy Creek through station RC18. Discharges from the north and south forested wetland areas for 1988-89, as for previous periods, accounted for an average of about 80 percent of the total discharge to Reedy Creek, with discharge from the percolation pond system through station PP7 accounting for the remaining 20 percent.

The total discharge to Reedy Creek from the three wetland systems (through RC23, RC18, and PP7), the total wastewater input from the treatment plant, and the difference between the total discharge from the wetland systems and the wastewater input, are illustrated by the monthly mean values shown in the lower part of figure 12. The top of the bar represents the total discharge to Reedy Creek, the shaded area represents the total wastewater input from the treatment 


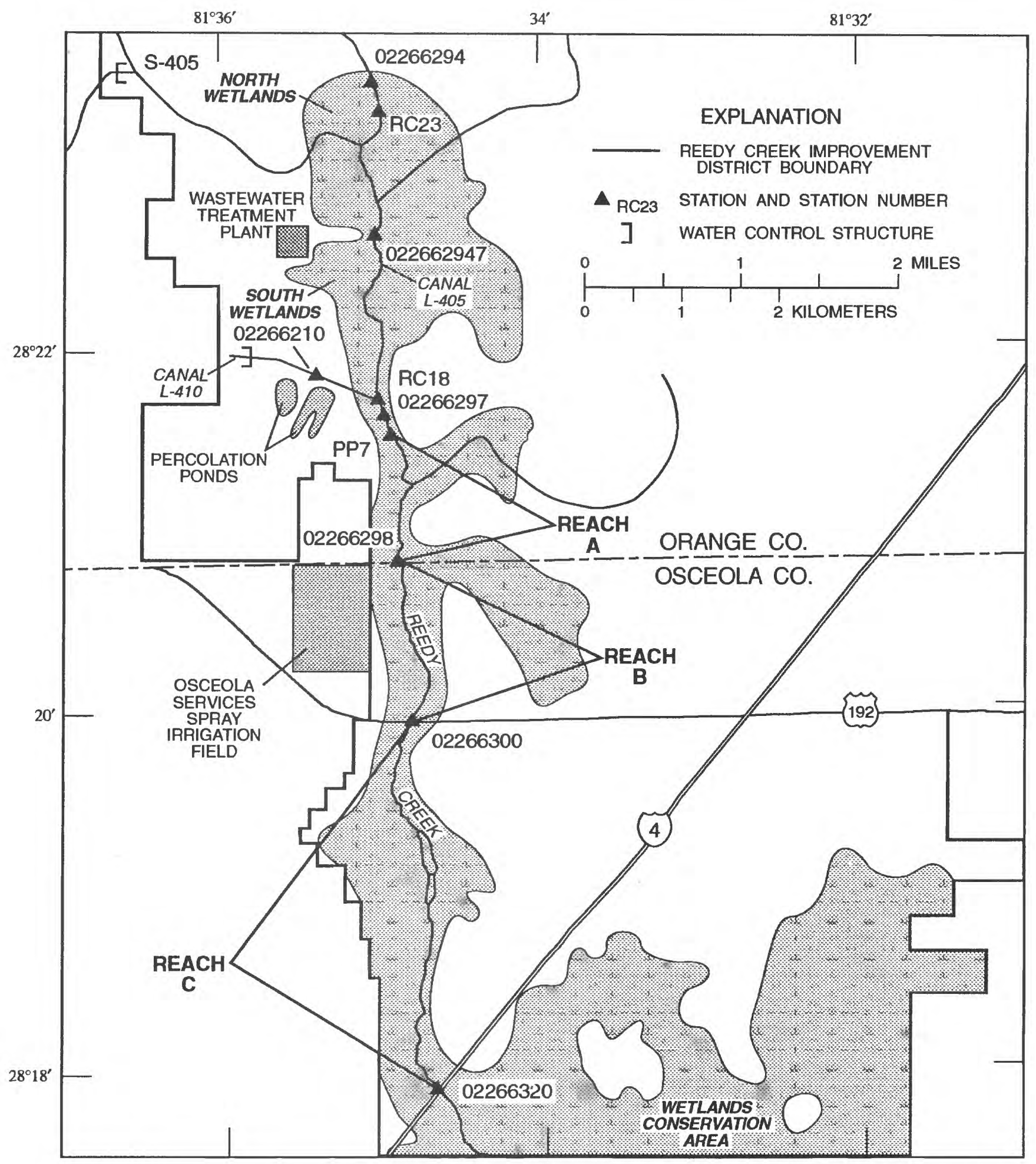

Figure 10. Locations of stations, study reaches, and hydrologic features of the north and south wetland areas in the central part of the study area. 


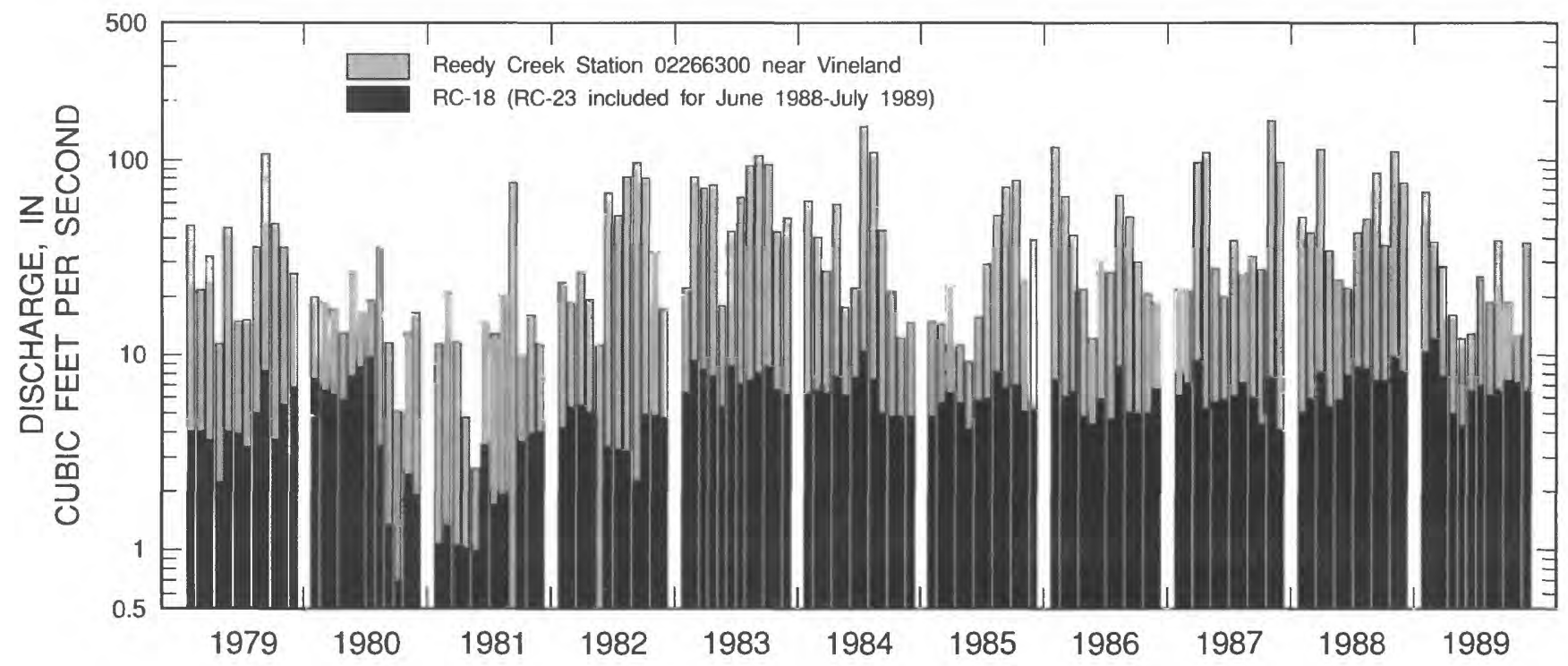

Figure 11. Monthly mean discharges for Reedy Creek at station 02266300 near Vineland and station RC18, $1979-89$.

plant, and the lower end of the bar represents the net flow added or taken in by the wetland and percolation pond systems after the wastewater input is subtracted. The wetland and percolation pond systems contributed nearly $0.7 \mathrm{ft}^{3} / \mathrm{s}$ to the total discharge to Reedy Creek during 1988-89. During dry periods, such as May 1988 and February through June 1989, the systems served as a sink for wastewater inputs. The net contributions of the three systems to the total discharge in the main stem of Reedy Creek ranged from $-2.6 \mathrm{ft}^{3} / \mathrm{s}$ in May 1989 to $+2.7 \mathrm{ft}^{3} / \mathrm{s}$ in November 1988 .

Discharge entering Reedy Creek from the wetland system (forested wetland areas and the percolation pond system) is diluted by flows through structure S-405 at station 02266294 upstream from RC23, flow from canal L-410 at station 02266210, and from inflow to Reedy Creek in the reaches downstream from station 02266297 (fig. 10). The relative contributions of the wetland system, discharge from canal L-410 at station 02266210, and discharge through structure S-405 (represented as discharge at station 022662947 less discharge at station RC23) are shown in figure 13 as monthly discharges for the common period of record, August 1988 through December 1989. Daily mean discharge statistics for these and other stations on Reedy Creek are given in table 4. As shown in figure 13 , the total wetlands discharge to Reedy Creek provided a relatively stable base flow, averaging $9.03 \mathrm{ft}^{3} / \mathrm{s}$. Discharges from structure S-405 (02266294) and canal L-410 (02266210) fluctuated widely and primarily were dependent on rainfall and runoff from their respective drainage areas.

Table 3. Wastewater inputs and discharges for north and south wetland areas and percolation pond system within the Reedy Creek Improvement District, central Florida, 1988-89 [All values given in cubic feet per second]

\begin{tabular}{|c|c|c|c|c|c|c|c|c|}
\hline & \multicolumn{2}{|c|}{$\begin{array}{c}\text { South } \\
\text { wetland area }\end{array}$} & \multicolumn{2}{|c|}{$\begin{array}{c}\text { North } \\
\text { wetland area }{ }^{1}\end{array}$} & \multicolumn{2}{|c|}{$\begin{array}{l}\text { Percolation } \\
\text { pond system }\end{array}$} & \multicolumn{2}{|c|}{ Totals } \\
\hline & Mean & Range & Mean & Range & Mean & Range & Mean & Range \\
\hline Total input & 4.32 & $0.26-9.79$ & 4.76 & $0.0-6.29$ & 1.42 & $0.0-3.47$ & 8.39 & $4.03-12.23$ \\
\hline Total discharge & 5.02 & $0.0-4.94$ & 5.75 & $0.14-16.14$ & 1.83 & $0.0-6.13$ & 9.05 & $1.55-33.03$ \\
\hline
\end{tabular}

${ }^{\mathrm{I}}$ Values are for period of operation, June 1988 through July 1989. 


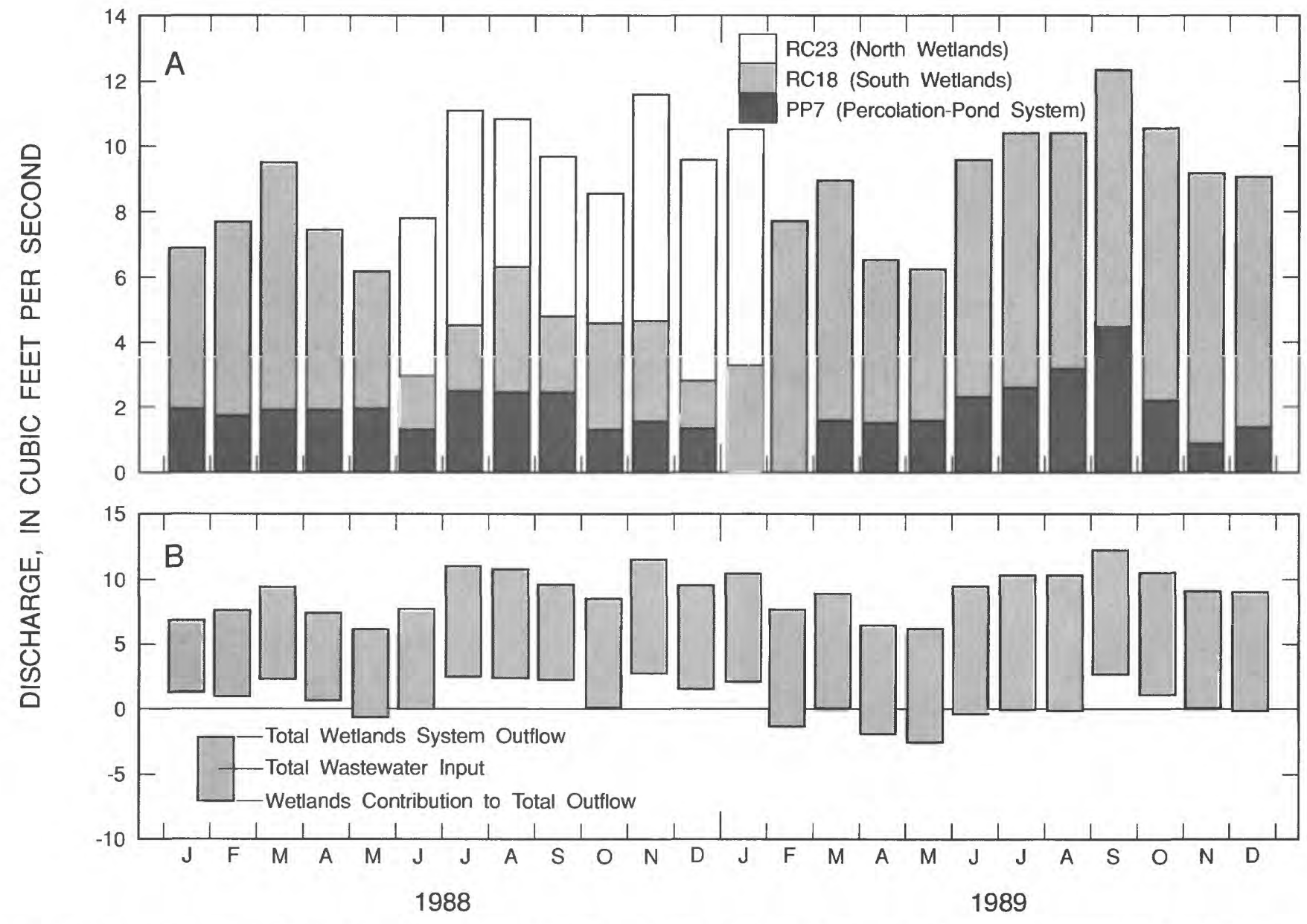

Figure 12. Monthly mean discharges for $(A)$ the north wetland, south wetland, and percolation-pond areas; and (B) the wetlands outflow, wastewater, and wetland contributions.

Monthly mean discharges of Reedy Creek immediately downstream from station PP7, calculated by addition of the various inflow upstream from that point, and discharge at station 02266298 downstream are shown in figure 13. The difference between the two bars in figure 13 reflects the discharge contribution of the wetland area between the two stations, which can also fluctuate in response to rainfall and moisture conditions. On average for the period shown, discharge for Reedy Creek at PP7 was $19.0 \mathrm{ft}^{3} / \mathrm{s}$, or almost 74 percent of the discharge at station 02266298. Percentages ranged from 53.9 percent in October 1988 to 100 percent in June 1989.

Monthly mean discharge from August 1988 through December 1989 at stations 02266298 and 02266300 are shown in figure 14 . The difference in discharge at these two stations reflects the inflow from the reach of Reedy Creek adjacent to the Osceola Services spray irrigation field (fig. 2). This area is used for the disposal of about $0.5 \mathrm{Mgal} / \mathrm{d}$ of sewage-treatment-plant effluent. During the period shown, discharge at station 02266298 averaged 63.5 percent of the discharge at station 02266300 (table 4), and ranged from 50.5 percent in September 1988 to 91.2 percent in November 1989 (fig. 14). The reach between stations 02266298 and 02266300 contributed an average of $14.8 \mathrm{ft}^{3} / \mathrm{s}$ of discharge or 36.5 percent of the total flow passing station 02266300.

\section{TRAVELTIME AND REAERATION COEFFICIENT MEASUREMENTS}

Three traveltime-reaeration coefficient measurements were made on reaches of Reedy Creek downstream from the sewage-treatment plant during the study period. These measurements were performed to evaluate the ability of Reedy Creek to assimilate oxygen-demanding materials without severe dissolved 


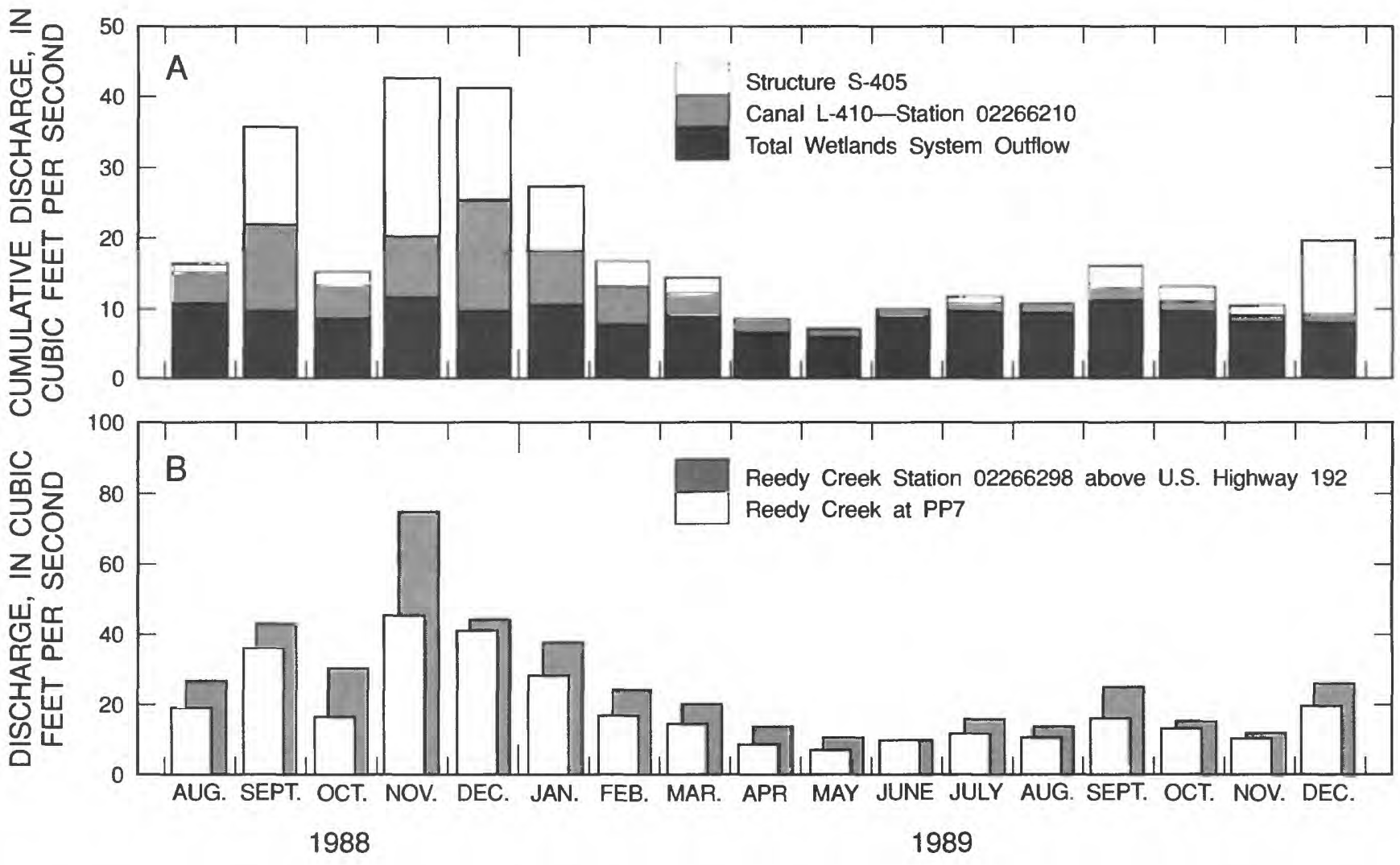

Figure 13. Monthly mean discharges during August 1988 to December 1989 for (A) structure S-405, canal L-410, and the wetland system outflow; and (B) Reedy Creek at stations 02266298 and PP7.

Table 4. Discharge statistics for Reedy Creek, August 1988 through December 1989

[All values given in cubic feet per second]

\begin{tabular}{lcl}
\hline \multicolumn{1}{c}{ Station or flow component } & Mean daily & Range \\
\hline Total wastewater input & 8.95 & $6.0-12$ \\
Total wetlands discharge & 9.03 & $3.0-33$ \\
$\begin{array}{l}\text { Station 022662947 } \\
\quad(\text { Canal 405 at force main near Vineland) }\end{array}$ & 7.69 & $0.0-315$ \\
$\begin{array}{l}\text { Station 02266210 } \\
\quad \text { (Canal L-410) }\end{array}$ & 4.33 & $1.0-36$ \\
$\begin{array}{l}\text { Reedy Creek at PP7 } \\
\quad \text { Reedy Creek below wetlands outflow) }\end{array}$ & 19.0 & $4.8-368$ \\
$\begin{array}{l}\text { Station 02266298 } \\
\quad(\text { Reedy Creek above U.S. Highway 192) }\end{array}$ & 25.8 & $6.8-846$ \\
$\begin{array}{l}\text { Station 02266300 } \\
\quad(\text { Reedy Creek at U.S. Highway 192) }\end{array}$ & 40.6 & $7.0-786$ \\
\hline
\end{tabular}




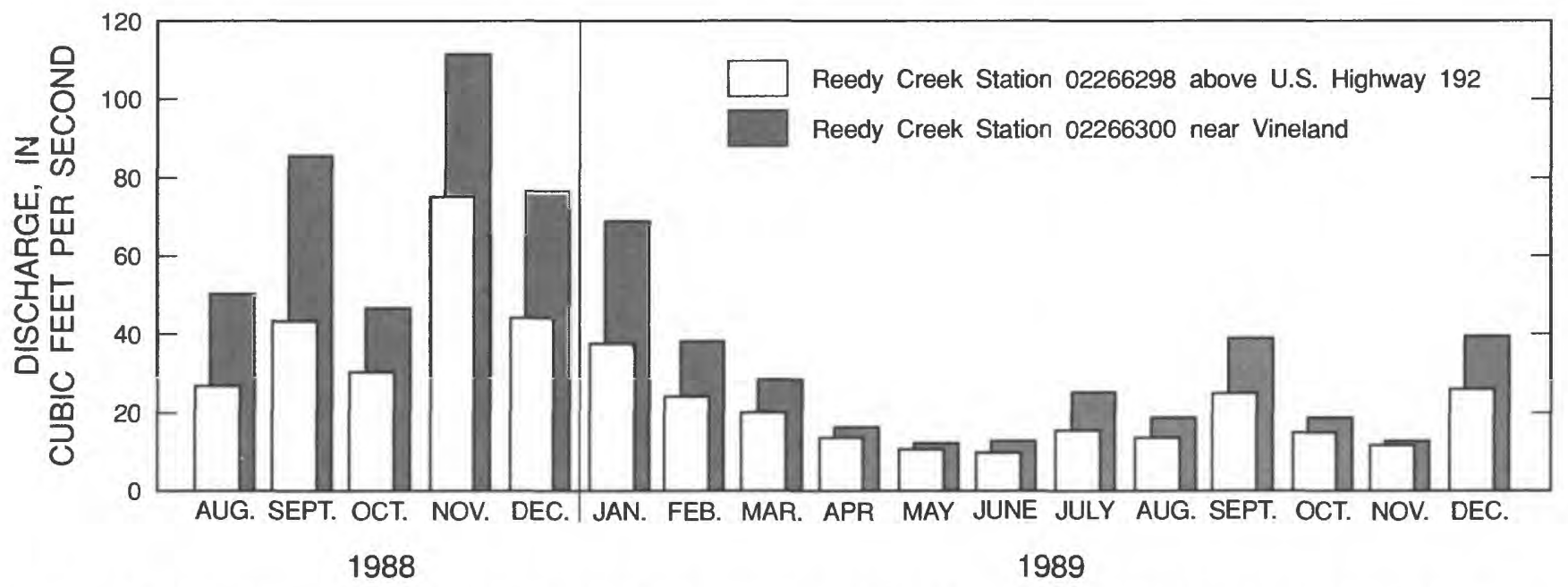

Figure 14. Monthly mean discharges for Reedy Creek at station 02266300 (near Vineland) and 02266298 (above U.S. Highway 192), August 1988 to December 1989.

oxygen depletion. The first two measurements were made on August 17 and November 3, 1988, on reaches $\mathrm{A}$ and B (fig. 10). Reach A is the $0.8 \mathrm{mi}$ segment of Reedy Creek between stations 02266297 and 02266298. Reach B is 1.06 mi in length and stretches between stations 02266298 and 02266300 . The third measurement was performed on April 20, 1989, on reach $\mathrm{C}$, which is $2.57 \mathrm{mi}$ in length, extending from station 02266300 to station 02266320 . All measurements utilized the constant-rate injection (CRI) method which involves the constant injection of a hydrocarbon gas and tracking of a slug injection of Rhodamine WT dye. For these measurements, propane was used as the hydrocarbon gas tracer. Reaeration coefficients were calculated from the gas concentrations downstream from the injection point and dye concentrations were used to determine traveltimes between stations and to account for dispersive effects in the streamflow. Detailed explanations and discussions of reaeration coefficient measurement methods can be found in reports by Kilpatrick and others (1987) and Hampson and Coffin (1989).

\section{Traveltime Determinations}

Dye concentrations measured on August 17 and November 3, 1988, at stations 02266297, 02266298 , and 02266300 are shown in figures 15 and 16 . For both measurements, the injection point was $0.18 \mathrm{mi}$ or $950 \mathrm{ft}$ upstream from station 02266297. The top graphs in both figures show the traveltimes for the leading edges, peaks, and trailing edges of the Rhodamine WT dye clouds. The trailing and leading edges were defined as 5 percent of the peak concentration and illustrate the dispersion of the dye cloud. These percentages were not used as cutoff values for coefficient or traveltime computations. Measured discharges for the August 17 measurement were $21.9 \mathrm{ft}^{3} / \mathrm{s}$ at station 02266297 , $22.0 \mathrm{ft}^{3} / \mathrm{s}$ at station 02266298 , and $32.0 \mathrm{ft}^{3} / \mathrm{s}$ at station 02266300 . For the November 3 measurement, discharges were $14.6 \mathrm{ft}^{3} / \mathrm{s}$ at station $02266297,16.2 \mathrm{ft}^{3} / \mathrm{s}$ at station 02266298 , and $19.0 \mathrm{ft}^{3} / \mathrm{s}$ at station 02266300 . Mean traveltimes were computed from the passage times of the dye-cloud centroids (centers of mass) at the measuring stations. Traveltimes for the August 17 measurement were 4.56 hours for reach $\mathrm{A}$ between stations 02266297 and 02266298 and 3.91 hours for reach B between stations 02266298 and 02266300 . Traveltimes were longer for the November 3 measurement (performed under conditions of lower discharge): 5.66 hours for reach A and 4.66 hours for reach B.

Estimated mean traveltimes for reaches A and B as functions of mean discharge at the lower end of the reach (station 02266298 for reach $\mathrm{A}$ and station 02266300 for reach B) are shown in figure 17 . The estimates were determined by relating the mean crosssectional velocity at the discharge measurement section to the mean velocity in the reach computed from the distance traveled and the measured traveltime. Mean cross-sectional velocities at the discharge measurement sections were computed for the range of discharges shown using the stage-discharge and stage-area relations for the measurement stations. Estimated mean velocities and traveltimes for the reaches were then 

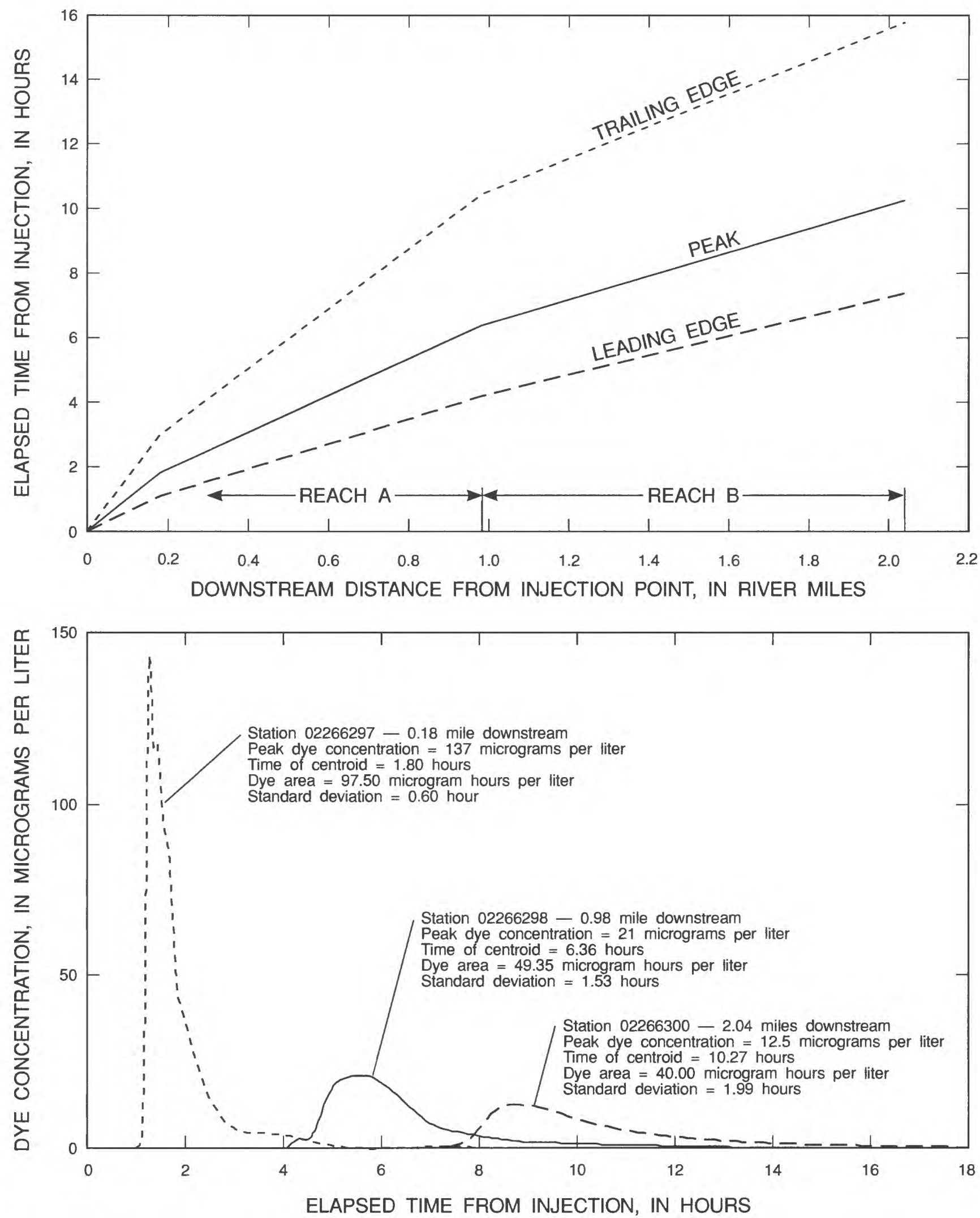

Figure 15. Traveltimes and dye concentrations for Reedy Creek reaches A and B, August 17, 1988. 

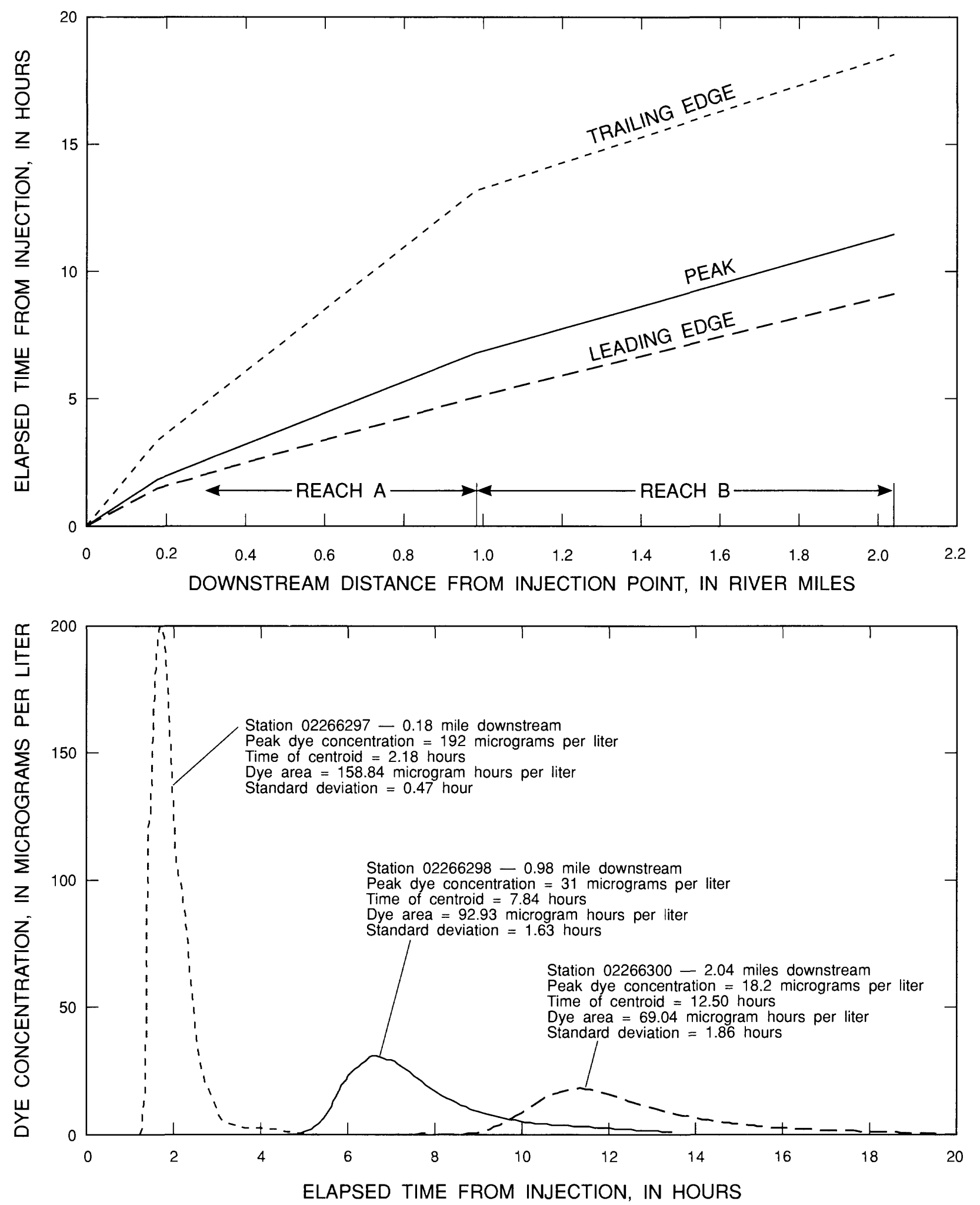

Figure 16. Traveltimes and dye concentrations for Reedy Creek reaches A and B, November 3, 1988. 


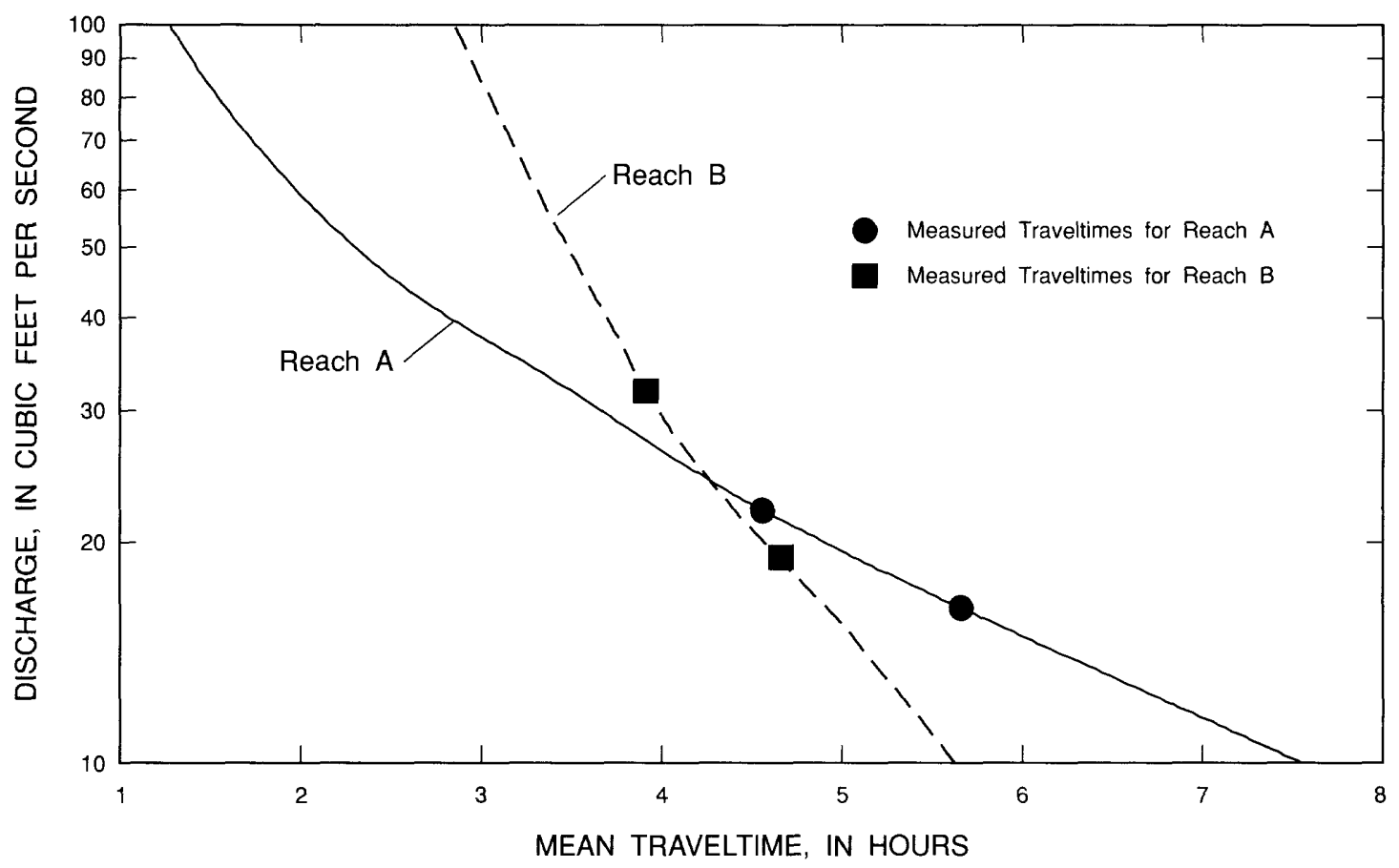

Figure 17. Estimated traveltime for Reedy Creek reaches $A$ and $B$ based on discharge.

computed using the relations derived from the measurements. Because the estimates are based on only two measurements, they should be used with caution. Relations between mean reach velocities and mean cross-sectional velocities at the discharge measurement sections might be considerably different for discharge regimes other than those used to make the measurements. The estimated traveltimes can be considered reliable in the discharge range bounded by the actual measurements, but should be considered speculative where extrapolation has been made outside this range. Accurate definition of the traveltime-discharge relation over the range of discharge for reaches $\mathrm{A}$ and $\mathrm{B}$ will require additional dye studies to cover the discharge range.

Dye concentrations for the April 20, 1989, measurement for reach $\mathrm{C}$ between stations 02266300 and 02266320 are shown in figure 18 . The injection point for the measurement was $0.18 \mathrm{mi}$ or $950 \mathrm{ft}$ upstream from station 02266300 . Measured discharges were $16.0 \mathrm{ft}^{3} / \mathrm{s}$ at station 02266300 and $21.3 \mathrm{ft}^{3} / \mathrm{s}$ at station 02266320 . The mean traveltime as calculated from the passage times of the Rhodamine WT dye-cloud centroids was 14.65 hours for the $2.57 \mathrm{mi}$ reach.

\section{Reaeration Coefficient Determinations}

The reaeration coefficient is a first-order rate constant in the basic gas absorption equation for water first applied to reaeration problems in the classic work of Streeter and Phelps (1925). The coefficient is a basic measurement of the rate at which the stream can absorb atmospheric oxygen to replace dissolved oxygen consumed by oxygen-demanding materials in the streamflow. The basic assumption used is that absorption (or inversely, desorption) of gas through a stream surface can be adequately described as a first-order process of the form

$$
\frac{d C_{g}}{d t}=K_{r} C_{g},
$$

where

$C_{g}$ is the gas concentration,

$t$ is time, and

$K_{r}$ is the absorption coefficient, or, in the case of dissolved oxygen, the reaeration coefficient (Kilpatrick and others, 1987).

Although the reaeration coefficient generally is reported as a single constant, it represents an average of many individual values within the stream reach (Tsivoglou, 1967). 

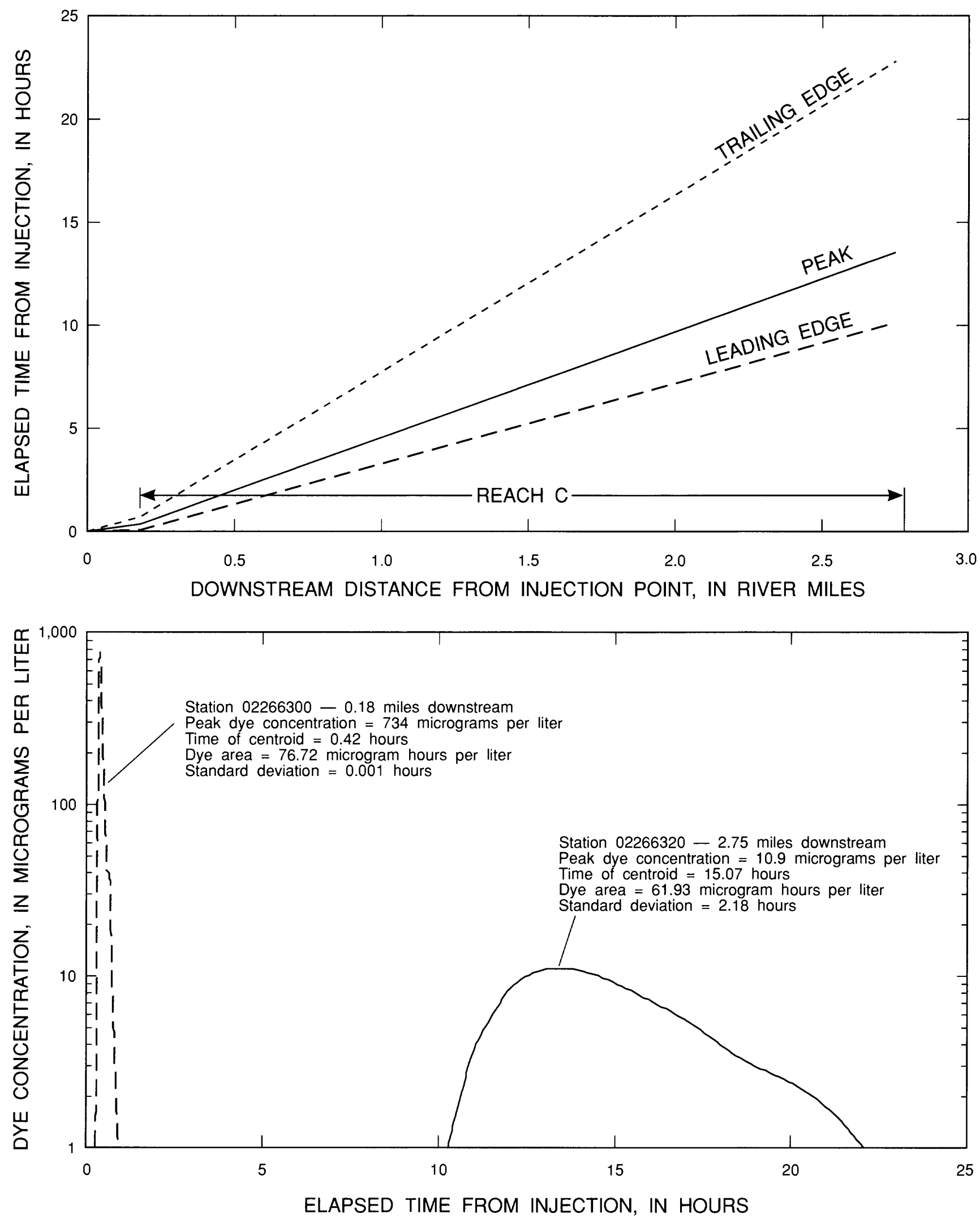

Figure 18. Traveltimes and dye concentrations for Reedy Creek reach C, April 20, 1989. 
The CRI method to measure reaeration coefficients used in this study involved the constant-rate injection of propane gas at the injection point for a time sufficient to establish steady-state propane concentrations at the downstream stations at which samples were collected. The method is used to assess the ability of the stream to desorb the propane gas tracer which can then be related to the capacity of the same stream reach to absorb atmospheric oxygen (Kilpatrick and others, 1987). The conversion factor for propane was determined by Rathbun and Grant (1978) in a series of laboratory studies using stirred tanks and was confirmed by Rainwater and Holley (1984). The resulting conversion equation was

where

$$
K_{r}=1.39 K_{p},
$$

$K_{r}$ is the reaeration coefficient, and

$K_{p}$ is the measured desorption coefficient for propane gas.

Once the steady-state propane concentrations, measured discharges, and Rhodamine WT dye-concentration have been determined, the desorption coefficients can be obtained by trial solutions of the equation

$$
\frac{\left(\bar{C}_{g} Q\right) u}{\left(\bar{C}_{g} Q\right) d}=\frac{\left[\int_{t=0}^{t=\infty} f\left(C_{d}, t\right) \exp \left(-K_{T} t\right) d t\right]}{\left[\int_{t=0}^{t=\infty} f\left(C_{d}, t\right) \exp \left(-K_{T} t\right) d t\right] d},
$$

where

$\bar{C}_{g}$ is mean propane gas concentration,

$f\left(C_{d}, t\right)$ is normalized dye concentrations as a function of time,

$t$ is time,

$K_{T}$ is trial desorption coefficient, and

$u$ and $d$ are subscripts that denote the upstream and downstream measuring sections.

In the equation, the left-hand term the ratio of the upstream gas mass in transport to that downstream. The bracketed expressions on the right are the integration of the normalized dye-concentration curve and the firstorder decay function for both the upstream and downstream measuring sections. Normalizing the dye concentration-time data consists of dividing by the area of the dye curve such that

$$
f\left(C_{d}, t\right)=C_{d}(t) / \int C_{d} d t
$$

Solution of the equation involves numerical calculations using a number of trial $\mathrm{K}_{\mathrm{T}}$ values. When the ratio on the right side of the equation agrees with the ratio on the left side, the trial value is considered as the correct desorption coefficient (Kilpatrick and others, 1987). The desorption coefficient can then be converted to a reaeration coefficient using the relation given previously.

Both the solubility of oxygen in water and the reaeration coefficient are functions of water temperature; therefore, valid comparisons between coefficients can only be made between values adjusted to a specified reference water temperature. The coefficients presented in this report are referenced to $20^{\circ} \mathrm{C}$ using the relation developed by Elmore and West (1961)

$$
K_{r 20{ }^{\circ} \mathrm{C}}=K_{r}(1.0241)^{20-T} \text {, }
$$

where

$K_{r} 20^{\circ} \mathrm{C}$ is reaeration coefficient adjusted to $20^{\circ} \mathrm{C}$,

$K_{r}$ is calculated reaeration coefficient from the measured data, and

$T$ is mean water temperature for the measurement in degrees Celsius.

Reaeration coefficient measurement data for reaches $\mathrm{A}, \mathrm{B}$, and $\mathrm{C}$ of Reedy Creek are given in table 5, which also includes the upstream and downstream discharges and the mean propane concentrations. The measured reaeration coefficients ranged from 6.38 day $^{-1}$ for reach C during the April 20, 1989, measurement to 13.16 day $^{-1}$ for reach B during the August 17, 1988, measurement. These values fall well within the range of reported values in a study by Hampson and Coffin (1989) of reaeration coefficients in 27 reaches of 12 selected Florida streams. Comparison of the results for August 17 and November 3, 1988, indicate that for reaches $\mathrm{A}$ and $\mathrm{B}$, the reaeration coefficient is quite sensitive to the discharge and mean velocity of Reedy Creek and that reaeration increases with increasing discharge. The data, however, do not justify the use of any of the equations used for coefficient calculation which were presented by Hampson and Coffin (1989). Additional measurements at other rates of discharge will be needed to construct an accurate relation between discharge and the reaeration coefficient for these reaches of Reedy Creek.

\section{WATER QUALITY}

Water-quality data collection during the study included the operation of continuous water-quality minimonitors and the collection of periodic waterquality samples for analysis of major constituents and nutrients. Minimonitors were used to record hourly 
Table 5. Reaeration coefficient measurement data for Reedy Creek

$\left[\mathrm{t}^{3} / \mathrm{s}\right.$, cubic feet per second; $\mu \mathrm{g} / \mathrm{L}$, micrograms per liter; ${ }^{\circ} \mathrm{C}$, degrees Celsius]

\begin{tabular}{|c|c|c|c|c|c|c|}
\hline Date & $\begin{array}{l}\text { Upstream } \\
\text { discharge } \\
\left(\mathrm{ft}^{3} / \mathrm{s}\right)\end{array}$ & $\begin{array}{c}\text { Downstream } \\
\text { discharge } \\
\left(\mathrm{ft}^{3} / \mathrm{s}\right)\end{array}$ & $\begin{array}{l}\text { Upstream } \\
\text { propane } \\
\text { concentra- } \\
\text { tion }(\mu \mathrm{g} / \mathrm{L})\end{array}$ & $\begin{array}{l}\text { Downstream } \\
\text { propane } \\
\text { concentra- } \\
\text { tion }(\mu \mathrm{g} / \mathrm{L})\end{array}$ & $\begin{array}{c}\text { Mean } \\
\text { traveltime } \\
\text { (hours) }\end{array}$ & $\begin{array}{c}\text { Reaeration } \\
\text { coefficient } \\
\text { at } 20^{\circ} \mathrm{C} \\
\left(\text { days }^{-1}\right)\end{array}$ \\
\hline \multicolumn{7}{|c|}{ Reach A--Station 02266297 to Station 02266298} \\
\hline $8-17-88$ & 21.9 & 22.0 & 161 & 26.3 & 4.56 & 12.23 \\
\hline $11-03-88$ & 14.6 & 16.2 & 140 & 37.3 & 5.66 & 7.66 \\
\hline \multicolumn{7}{|c|}{ Reach B--Station 02266298 to Station 02266300} \\
\hline $8-17-88$ & 22.0 & 32.0 & 26.3 & 3.4 & 3.91 & 13.16 \\
\hline $11-03-88$ & 16.2 & 19.0 & 37.3 & 11.0 & 4.66 & 7.96 \\
\hline \multicolumn{7}{|c|}{ Reach C--Station 02266300 to Station 02266320} \\
\hline $4-20-89$ & 16.0 & 21.3 & 51.0 & 1.9 & 14.65 & 6.38 \\
\hline
\end{tabular}

water temperature, specific conductance, and dissolved oxygen concentration at four stations along Reedy Creek from 1983 through 1989. At on one of these stations a minimonitor had been operated since 1980 . Minimonitors were recalibrated and checked every at about 3-week intervals. Minimonitor measurements were also cross-checked with field determinations made during the collection of samples by the USGS and the RCID. Individual hourly determinations of water temperature are conservatively estimated accurate to $\pm 0.5^{\circ} \mathrm{C}$, specific conductance values to $\pm 50 \mu \mathrm{S} / \mathrm{cm}$, and dissolved oxygen concentrations to $0.5 \mathrm{mg} / \mathrm{L}$.

Water samples, collected quarterly at eight stations within the RCID, were analyzed to determine major constituent concentrations. The samples were collected on a monthly basis during 1986-88 and on a quarterly basis during 1989. All laboratory analyses of these samples were performed by a U.S. Geological Survey laboratory, by methods described by Skougstad and others (1979) and Fishman and Brown (1976). The RCID furnished additional nutrient analyses for five stations during calendar years 1988-89. These samples were collected at intervals ranging from daily to weekly and were analyzed by methods approved by the U.S. Environmental Protection Agency.

\section{Water Temperature}

Water temperature is an important water-quality property because of dependence on temperature of biological activity, mineral solubilities, reaction kinetics, and other factors which influence the concentrations of dissolved substances in water. The solubility of atmospheric oxygen in water as well as the reaeration coefficient are temperature dependent. Water temperatures were recorded hourly at the four stations equipped with water-quality minimonitors: stations 022662947 , 02266298, 02266300, and 02266320 (fig. 10). Temperature data at one of these stations, Reedy Creek near Vineland (station 02266300), is available for 1980-89 and is shown in figure 19. The mean daily water temperature during 1980-89 at the Vineland station was $21.0^{\circ} \mathrm{C}$, and ranged from $3.7^{\circ} \mathrm{C}$ on December 25 , 1989 , to $28.8^{\circ} \mathrm{C}$ on August 6,1989 . The daily mean water temperatures exhibit a marked seasonality, characteristic of central Florida, with low temperatures ranging from about 10 to $15^{\circ} \mathrm{C}$ during the winter months and high temperatures exceeding $25^{\circ} \mathrm{C}$ during the summer months.

Hourly water temperatures at the Vineland station for the period 1980-89 ranged from $2.2^{\circ} \mathrm{C}$ on December 25,1989 , to $33.4{ }^{\circ} \mathrm{C}$ on August 30,1983 . On a daily basis, hourly water temperatures generallyfluctuated from daily minimum temperatures during the midmorning hours to daily maximum temperatures during the late afternoon. Daily temperature ranges averaged $2.2{ }^{\circ} \mathrm{C}$ at the Vineland station for $1980-89$ and ranged from $0.2^{\circ} \mathrm{C}$ on June 23, 1982, to $8.7^{\circ} \mathrm{C}$ on August 30, 1983 . The greatest daily temperature ranges were associated with low-flow periods in the hot summer months and with the passage of strong, winter cold fronts. 


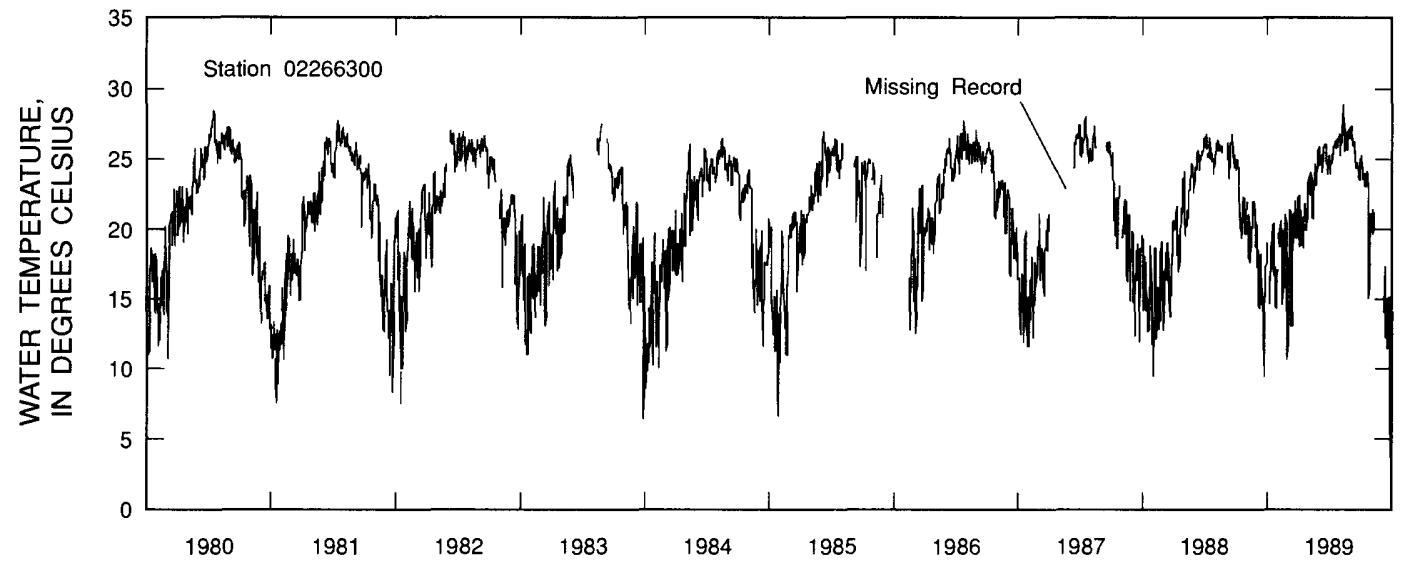

Figure 19. Daily mean water temperature for station 02266300, Reedy Creek near Vineland, 1980-89.

The period of record common for all four Reedy Creek stations equipped with water-quality minimonitors was 1983-89. During this period, daily mean water temperatures did not significantly differ for stations 02266298, 02266300, and 02266320. Daily mean water temperatures during this period generally were higher at station 022662947 because it is more exposed to direct sunlight and generally has a much lower streamflow than the other stations. Mean daily water temperatures at the four stations for 1983-89 are given in table 6 .

The similarity in mean water temperatures at stations 02266298,02266300 , and 02266320 also extended to the hourly recordings. The stations show similar diurnal variations with little difference between hourly water temperatures, as illustrated in figure 20
Table 6. Water temperature statistics for stations on Reedy Creek, 1983-89

[Temperature values are in degrees Celsius; mean temperature is the arithmetic mean of individual daily mean temperatures]

\begin{tabular}{lcc}
\hline \multicolumn{1}{c}{ Station } & $\begin{array}{c}\text { Mean } \\
\text { temperature }\end{array}$ & $\begin{array}{c}\text { Standard } \\
\text { deviation }\end{array}$ \\
\hline 022662947 & 22.7 & 4.7 \\
02266298 & 20.9 & 4.3 \\
02266300 & 20.9 & 4.3 \\
02266320 & 20.9 & 4.3 \\
\hline
\end{tabular}

for May 4 and 5, 1989. Daily water temperature fluctuations were slightly greater at stations 02266300 and 02266320 where the stream receives more exposure to sunlight than at station 02266298 where the stream is covered by a thick canopy trees.

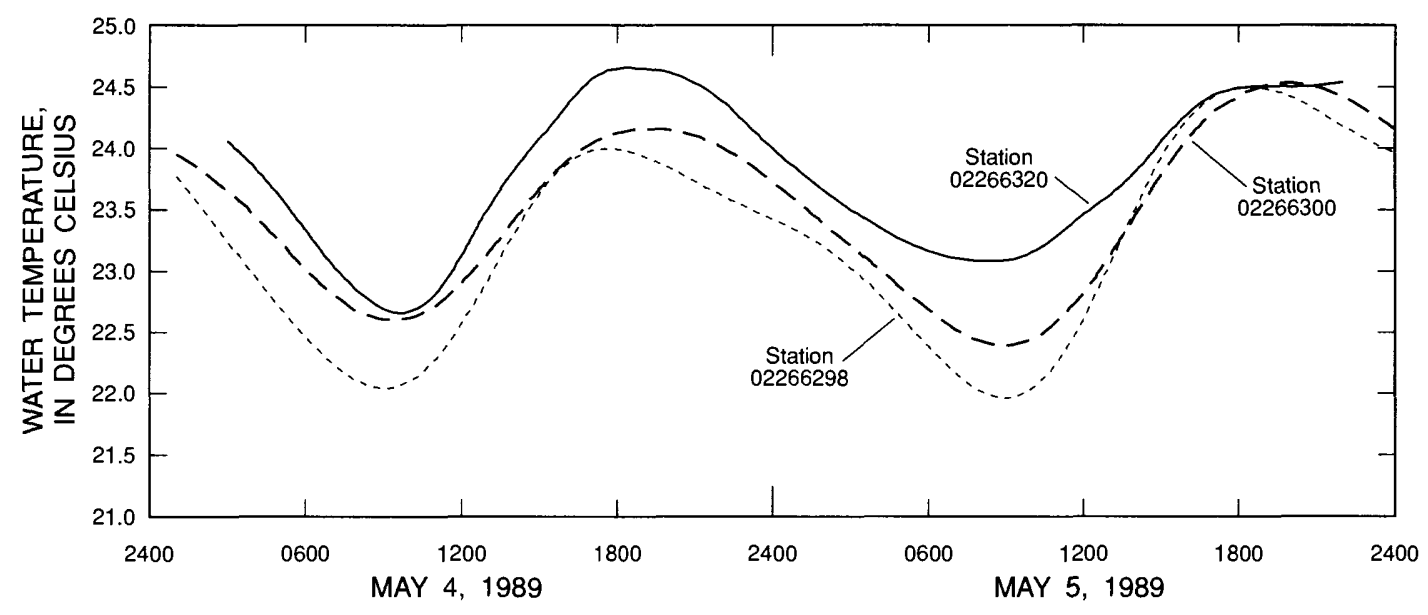

Figure 20. Hourly water temperature for three stations on Reedy Creek, May 4-5, 1989. 


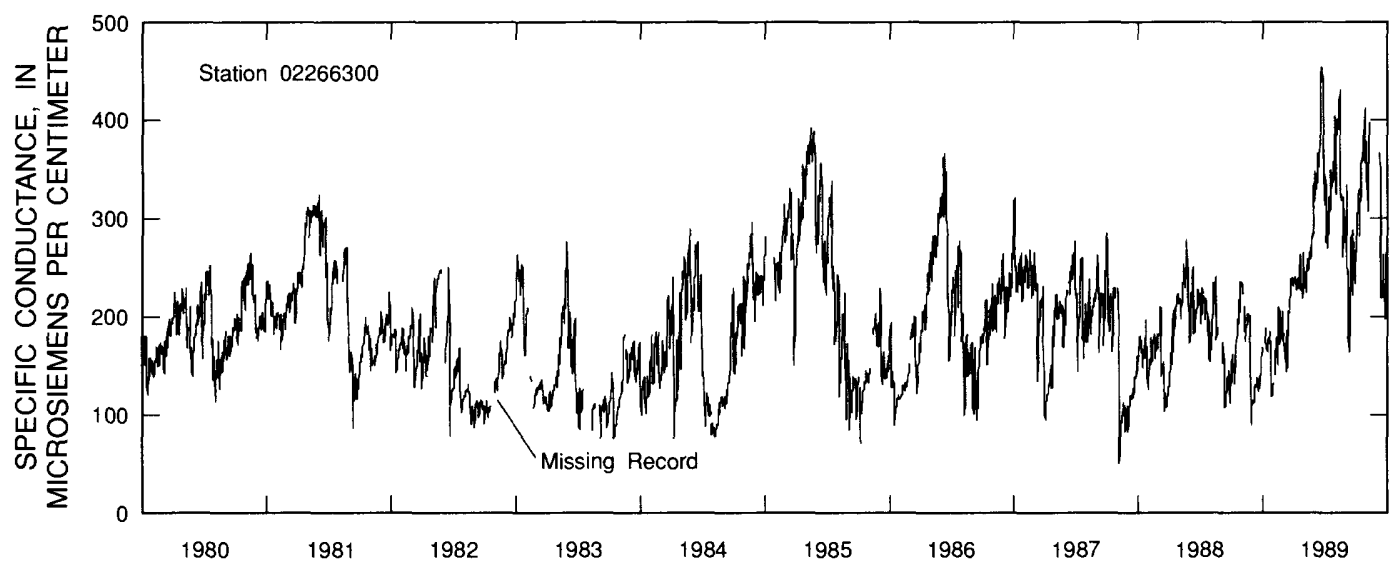

Figure 21. Daily mean specific conductance for station 02266300, Reedy Creek near Vineland, 1980-89.

\section{Specific Conductance}

Specific conductance values were recorded hourly at stations $022662947,02266298,02266300$, and 02266320 during the study. Specific conductance values did not indicate any regular daily variation. Daily mean specific conductance values averaged 194 $\mu \mathrm{S} / \mathrm{cm}$ during the period $1980-89$ at station 02266300 (Reedy Creek near Vineland, fig. 21), and ranged from $50 \mu \mathrm{S} / \mathrm{cm}$ on November 4,1987 , to $454 \mu \mathrm{S} / \mathrm{cm}$ on June 17, 1989, with a standard deviation of $64 \mu \mathrm{S} / \mathrm{cm}$.

Specific conductances values at all four stations varied inversely with discharge, so changes in specific conductances shown in figure 21 generally reflect changes in discharge. An example of this relation is the relatively high specific conductance during the extended dry period from late 1984 through the first half of 1985 . The increase in specific conductance in 1989, however, is not due to lower than average discharge but reflects a change in the wastewater discharged to Reedy Creek. During 1989, mixing of artificial seawater from the large seaquarium in EPCOT Center (fig. 2) with wastewater to be treated at the RCID treatment plant noticeably increased the specific conductance of the effluent.

This increase is also evident in the specific conductance statistics listed in table 7. Mean daily specific conductance values at stations downstream from the wastewater discharges (stations 02266298, 02266300, and 02266320) are higher for calendar year 1989 than for the 1983-89 period.

For most of the 1983-89 period of record, runoff and ground-water seepage have reduced specific conductance in the reaches downstream from the
Table 7. Specific conductance statistics for stations on Reedy Creek

[All values given in microsiemens per centimeter at 25 degrees Celsius]

\begin{tabular}{lcc}
\hline \multicolumn{1}{c}{ Station } & $\begin{array}{c}\text { Mean specific } \\
\text { conductance }\end{array}$ & Range \\
\hline 1983 through 1989 & & \\
022662947 & 149 & $71-257$ \\
02266298 & 214 & $89-515$ \\
02266300 & 194 & $50-454$ \\
02266320 & 186 & $57-447$ \\
1989 & & \\
02266298 & & \\
02266300 & 236 & $101-370$ \\
02266320 & 243 & $118-454$ \\
\hline
\end{tabular}

wastewater discharge points. Monthly mean specific conductance values for stations 02266298,02266300 , and 02266320 (fig. 10) for calendar years 1985-89 (fig. 22) illustrate the dilution effect.

\section{Major Constituents}

Samples for the analysis of major water-quality constituents were collected on a quarterly basis at eight stations within the RCID between October 1985 and December 1989. The major constituents--calcium, magnesium, potassium, sodium, bicarbonate (alkalinity), chloride, and sulfate--generally account for the bulk of the ionic composition and the majority of the dissolved solids in natural water. Summary statistics for the major constituent analyses performed on samples from RCID streams are listed in table 8 . 


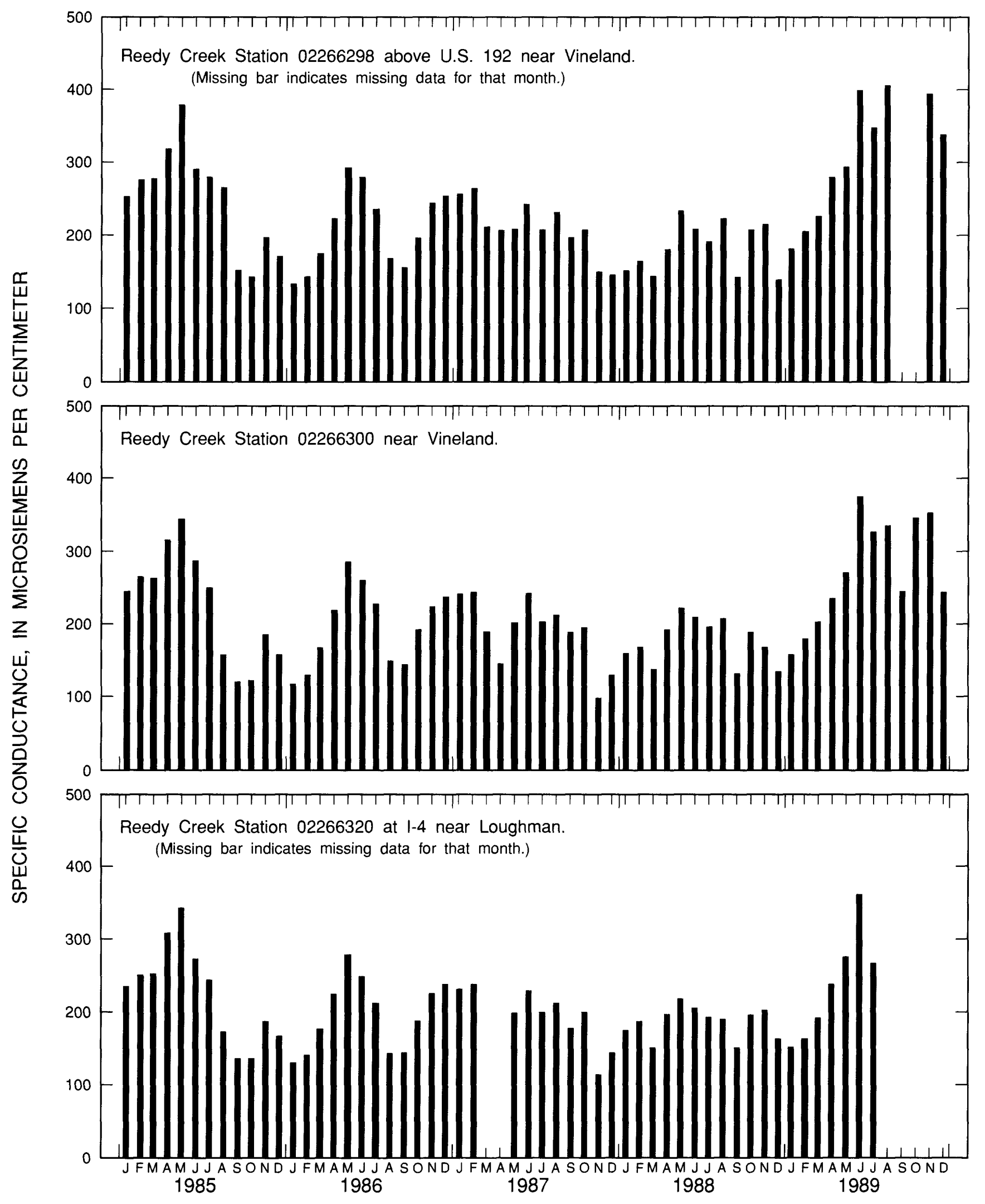

Figure 22. Monthly mean specific conductance for stations 02266298, 02266300, and 02266320 on Reedy Creek, 1985-89. 


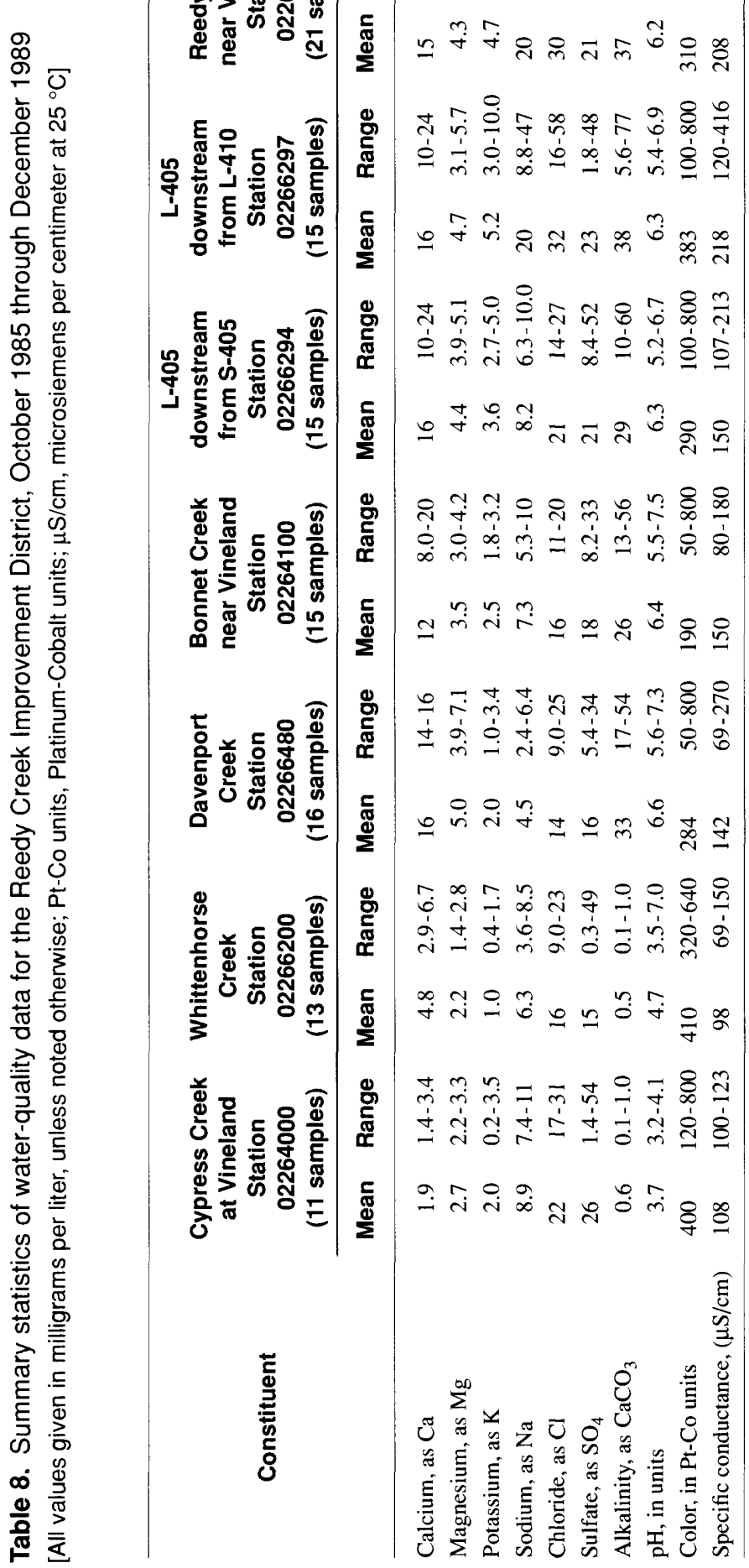


Cypress (station 02264000) and Whittenhorse (station 02266200) Creeks (fig. 2) are typical of inflows to the RCID and reflect the swampy, forested wetland character of their respective drainage basins. Water in these tributary streams is soft (specific conductance less than $150 \mu \mathrm{S} / \mathrm{cm}$ ), acidic ( $\mathrm{pH}$ less than 5.0 and alkalinity less than $1.0 \mathrm{mg} / \mathrm{L}$ ), and highly colored (color greater than 400 Pt-Co units). Davenport Creek (station 02266480) is also a small tributary stream with a drainage basin similar to those of Cypress and Whittenhorse Creeks. The water in Davenport Creek, however, contains much higher levels of calcium and alkalinity, higher $\mathrm{pH}$, and lower color than water in Cypress and Whittenhorse Creeks. This probably is because of the use of water from the Floridan aquifer system for irrigation of citrus in that part of the drainage basin immediately upstream from station 02266480 . In this area, water from the Floridan aquifer system is predominantly a calcium bicarbonate type with low concentrations of sodium, potassium, sulfate, and chloride (German, 1986). The analytical results for water samples from Davenport Creek are consistent with a mixture of Floridan aquifer water and a softer, more acidic water typical of a central Florida forested wetlands stream.

Wastewater discharges and runoff from developed areas can alter concentrations of major constituents in a receiving stream and apparently affects the chemical composition of water flowing through the RCID. Station 02264100 (Bonnet Creek near Vineland) is located downstream from a major hotel development complex at Lake Buena Vista and water from this station differs in quality from the inflow from Cypress Creek. The largest differences are the higher concentrations of calcium and alkalinity in Bonnet Creek. This difference in the two waters is also reflected in the higher $\mathrm{pH}$ in Bonnet Creek as opposed to Cypress Creek, and in lower levels of dissolved organic carbon in Bonnet Creek as reflected in the lower values for color. These differences are probably due to runoff from the developed areas into Bonnet Creek and also probably reflect the inflow of Floridan aquifer water which is used for water supply and irrigation in the upstream areas into Bonnet Creek.

The quality of water at station 02266297 (L-405 downstream from L-410) is affected by wastewater discharges into Reedy Creek from the north and south wetland areas through stations RC18 and RC23. Concentrations of sodium and chloride, total alkalinity, and color are elevated at station 02266297 as compared to values at station 02266294 , immediately upstream from the wastewater discharge points. The results from analyses of water samples from stations 02266300 and 02266500 farther downstream reflect slight decreases in concentrations of major constituents due to dilution. Overall, the data collected during this study indicate that the influence of wastewater discharge with respect to major constituents probably extends to and beyond the southern boundary of the RCID. The concentrations of major constituents, however, generally do not exceed water-quality standards established by FDER.

\section{Dissolved Oxygen}

Dissolved oxygen is of major interest in surfacewater systems because of its significance in the maintenance of aquatic life as well as in the protection of aesthetic qualities (U.S. Environmental Protection Agency, 1986). Historically, requirements of wastewater treatment have been based largely on the prevention of dissolved oxygen depletion in receiving-water bodies and the maintenance of minimum dissolved oxygen concentrations. The FDER minimum dissolved oxygen concentration criterion of $5.0 \mathrm{mg} / \mathrm{L}$ (Florida Department of State, 1978) is applicable to most of the natural water bodies in the RCID.

During the study, dissolved oxygen concentrations were recorded hourly at stations 022662947 , 02266298,02266300 , and 02266320 (fig. 10). Daily mean dissolved oxygen concentrations at station 02266300 (Reedy Creek near Vineland, fig. 23) averaged $4.8 \mathrm{mg} / \mathrm{L}$ for the period $1980-89$ with a standard deviation of $1.4 \mathrm{mg} / \mathrm{L}$. Daily mean dissolved oxygen concentrations ranged from $0.6 \mathrm{mg} / \mathrm{L}$ on June 4, 1985 , to $9.8 \mathrm{mg} / \mathrm{L}$ on March 3, 1980. Daily maximum dissolved oxygen concentrations during this period ranged from 1.8 to $10.4 \mathrm{mg} / \mathrm{L}$, with a mean of $5.4 \mathrm{mg} / \mathrm{L}$ and a median concentration of $5.4 \mathrm{mg} / \mathrm{L}$. Daily minimum dissolved oxygen concentrations ranged from 0.1 to 9.3 $\mathrm{mg} / \mathrm{L}$, with a mean of $4.6 \mathrm{mg} / \mathrm{L}$ and a median of $4.5 \mathrm{mg} / \mathrm{L}$.

Daily mean dissolved oxygen concentrations fluctuate seasonally (fig. 23), largely in response to seasonal water temperature changes. Dissolved oxygen concentrations commonly are lowest during the summer months when water temperatures are high and highest during the winter months when water temperatures are low (fig. 19). Although temperature affects several factors influencing dissolved oxygen concentrations in water, such as photosynthetic oxygen production and reaeration rates, the most notable temperature effect is on oxygen solubility in water. 


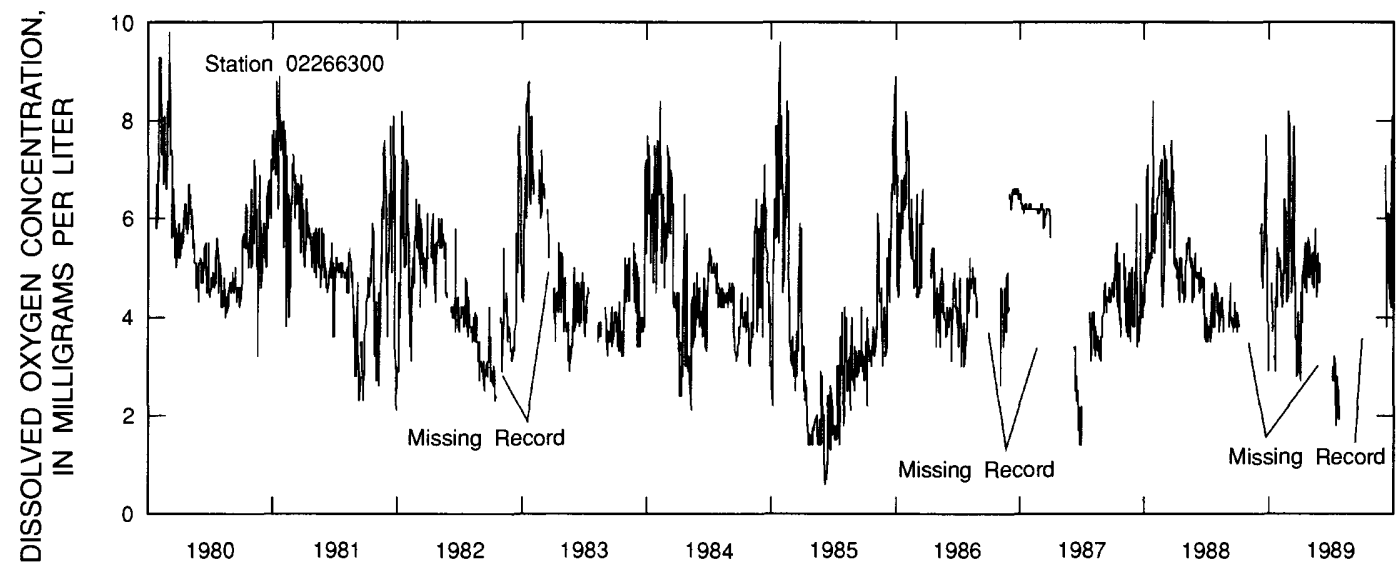

Figure 23. Daily mean dissolved oxygen concentrations for station 02266300 , Reedy Creek near Vineland, 1980-89.

In this report, daily mean oxygen saturation concentrations (concentrations at which water is fully saturated with atmospheric oxygen) were used to compute percent saturation and were computed using daily mean water temperatures and the following equation:

$$
\begin{aligned}
\ln \left(C_{s}\right)= & -139.34411+\left(1.575701 \times 10^{5} / T\right) \\
& -\left(6.642308 \times 10^{7} / T^{2}\right)+\left(1.2438 \times 10^{10} / T^{3}\right) \\
& -\left(8.621949 \times 10^{11} / T^{4}\right),
\end{aligned}
$$

where

$\ln \left(C_{s}\right)$ is natural logarithm of the saturation concentration, and

$T$ is absolute temperature in degrees Kelvin (degrees Celsius + 273.15).

This equation was developed by Benson and Krause (1984) and is recommended by the American Public Health Association (1985). Standard atmospheric pressure was assumed for all calculations.
Mean monthly dissolved oxygen concentrations, standard deviations, ranges, percent saturation, and 5.0 $\mathrm{mg} / \mathrm{L}$ exceedance values (in percent) for mean daily values at station 02266300 for $1980-89$ are given in table 9 . The seasonality of dissolved oxygen concentrations is indicated by the data in table 9 . Mean monthly concentrations ranged from $3.7 \mathrm{mg} / \mathrm{L}$ in September to $6.2 \mathrm{mg} / \mathrm{L}$ in January. The daily mean percent saturation for the entire 1980-89 period averaged 52.5 percent and ranged from 8.0 to 90 percent. On a monthly basis, daily mean percent saturations ranged from 44.5 percent for September to 61.6 percent for February.

Exceedance values for the FDER minimum dissolved oxygen criterion of $5.0 \mathrm{mg} / \mathrm{L}$ ranged from 0.0 percent for September to 82.7 percent for January. The daily mean dissolved oxygen concentration exceeded

Table 9. Monthly summary of dissolved oxygen concentrations for station 02266300, calendar years 1980 through 1989

[All values in milligrams per liter; $\mathrm{mg} / \mathrm{L}$, milligrams per liter]

\begin{tabular}{lccccc}
\hline Month & Mean & $\begin{array}{c}\text { Standard } \\
\text { deviation }\end{array}$ & Range & $\begin{array}{c}\text { Percent } \\
\text { saturation }\end{array}$ & $\begin{array}{c}\mathbf{5 . 0} \mathbf{m g} / \mathbf{L} \\
\text { exceedance } \\
\text { (percent) }\end{array}$ \\
\hline January & 6.2 & 1.4 & $2.2-9.6$ & 60.2 & 82.7 \\
February & 6.1 & 1.2 & $3.1-9.3$ & 61.6 & 77.6 \\
March & 5.5 & 1.2 & $2.5-9.8$ & 58.8 & 70.2 \\
April & 4.6 & 1.3 & $1.4-6.7$ & 50.8 & 70.2 \\
May & 4.4 & 1.2 & $1.4-6.5$ & 50.6 & 34.1 \\
June & 3.9 & 1.8 & $0.6-5.8$ & 46.8 & 9.1 \\
July & 4.0 & 1.0 & $1.4-5.6$ & 48.9 & 10.0 \\
August & 4.0 & 0.6 & $2.1-5.4$ & 51.7 & 4.6 \\
September & 3.7 & 0.7 & $2.3-5.0$ & 44.5 & 0.0 \\
October & 4.2 & 1.0 & $2.1-6.1$ & 48.2 & 23.6 \\
November & 4.6 & 1.0 & $2.6-7.6$ & 50.3 & 28.4 \\
December & 5.4 & 1.4 & $2.1-8.9$ & 53.3 & 58.5 \\
\hline
\end{tabular}


Table 10. Summary of dissolved oxygen concentrations for stations 02236500 and 02266300 during common period of record, 1982-88

[All values in milligrams per liter; mg/L, milligrams per liter; --, no data]

\begin{tabular}{|c|c|c|c|c|c|}
\hline & Mean & $\begin{array}{l}\text { Standard } \\
\text { deviation }\end{array}$ & Range & Median & $\begin{array}{c}5.0 \mathrm{mg} / \mathrm{L} \\
\text { exceedance } \\
\text { (percent) }\end{array}$ \\
\hline \multicolumn{6}{|l|}{ Station 02236500} \\
\hline $\begin{array}{l}\text { Daily minimum } \\
\text { Daily mean } \\
\text { Daily maximum } \\
\text { Daily variation (maximum } \\
\text { minus minimum) }\end{array}$ & $\begin{array}{l}4.4 \\
4.85 \\
5.1 \\
0.7\end{array}$ & $\begin{array}{l}1.3 \\
1.4 \\
1.4 \\
0.5\end{array}$ & $\begin{array}{l}0.8-8.6 \\
1.6-8.9 \\
2.0-9.5 \\
0.0-4.2\end{array}$ & $\begin{array}{l}4.3 \\
4.6 \\
5.1 \\
0.5\end{array}$ & $\begin{array}{c}28.8 \\
37.4 \\
51.4 \\
--\end{array}$ \\
\hline \multicolumn{6}{|l|}{ Station 02266300} \\
\hline $\begin{array}{l}\text { Daily minimum } \\
\text { Daily mean } \\
\text { Daily maximum } \\
\text { Daily variation (maximum } \\
\text { minus minimum) }\end{array}$ & $\begin{array}{l}4.3 \\
4.5 \\
5.0 \\
0.8\end{array}$ & $\begin{array}{l}1.2 \\
1.3 \\
1.4 \\
0.5\end{array}$ & $\begin{array}{l}1.1-8.4 \\
1.4-8.9 \\
1.8-9.2 \\
0.1-3.5\end{array}$ & $\begin{array}{l}4.1 \\
4.3 \\
4.7 \\
0.6\end{array}$ & $\begin{array}{c}22.6 \\
28.2 \\
41.2 \\
--\end{array}$ \\
\hline
\end{tabular}

the $5.0 \mathrm{mg} / \mathrm{L}$ minimum standard for 38.6 percent of the days of record for 1980-89. Daily minimum dissolved oxygen concentrations exceeded the standard for 33.8 percent of the days and daily maximums exceeded the standard for 57.7 percent of the days of record for the 1980-89 period.

From 1982 through 1988, background dissolved oxygen concentrations were recorded at station 02236500 on Big Creek (fig. 1), to provide comparison data for station 02266300 on Reedy Creek. Big Creek drains an approximately $68 \mathrm{mi}^{2}$, undeveloped basin about $5 \mathrm{mi}$ west of the RCID. Big Creek and its drainage basin are typical of many predominantly forested wetland systems in Florida and resemble conditions prevalent in the Reedy Creek basin prior to development. Despite the lack of development upstream from station 02236500 , dissolved oxygen concentrations in Big Creek frequently do not exceed the $5.0 \mathrm{mg} / \mathrm{L}$ FDER minimum standard. In a study of 1982-86 data, Hampson (1989) reported that the major factors controlling dissolved oxygen concentrations in Big Creek were water temperature and the presence of naturally occurring oxygen-demanding materials.

A summary of daily mean dissolved oxygen concentrations for stations 02236500 and 02266300 for 1,692 common days of record (days for which records were available at both sites) during the $1982-88$ period are given in table 10. During this period, water temperatures at the two stations were very similar. The daily mean water temperature at station 02266300 during the common period of record was $21.4{ }^{\circ} \mathrm{C}$ with a standard deviation of $4.0^{\circ} \mathrm{C}$ and ranged from 6.4 to $28.0^{\circ} \mathrm{C}$. The daily mean water temperature at station 02236500 was $21.2^{\circ} \mathrm{C}$ with a standard deviation of $4.2^{\circ} \mathrm{C}$ and ranged from 8.7 to $28.6^{\circ} \mathrm{C}$. Daily mean dissolved oxygen concentrations at station 02266300 were, on average, only $0.3 \mathrm{mg} / \mathrm{L}$ lower than concentrations at station 02236500 which is unaffected by development. The somewhat lower dissolved oxygen concentrations may reflect the effect of upstream wastewater discharges into Reedy Creek but also might be a result of physical differences in the two streams. Reedy Creek is a larger and deeper stream and probably has a somewhat lower reaeration capacity.

On average, daily minimum and maximum dissolved oxygen concentrations at stations 02236500 and 02266300 during the common period of record were almost identical. Concentrations at station 02266300 on Reedy Creek were, on average, less than $0.1 \mathrm{mg} / \mathrm{L}$ lower (table 10). Daily variations in dissolved oxygen concentrations are similar at the two stations, indicating that biological conditions relative to the photosynthetic production of oxygen generally are similar in the two streams. This similarity indicates that the wastewater discharges into Reedy Creek probably have not notably enhanced productivity in the stream reach upstream from station 02266300 . 


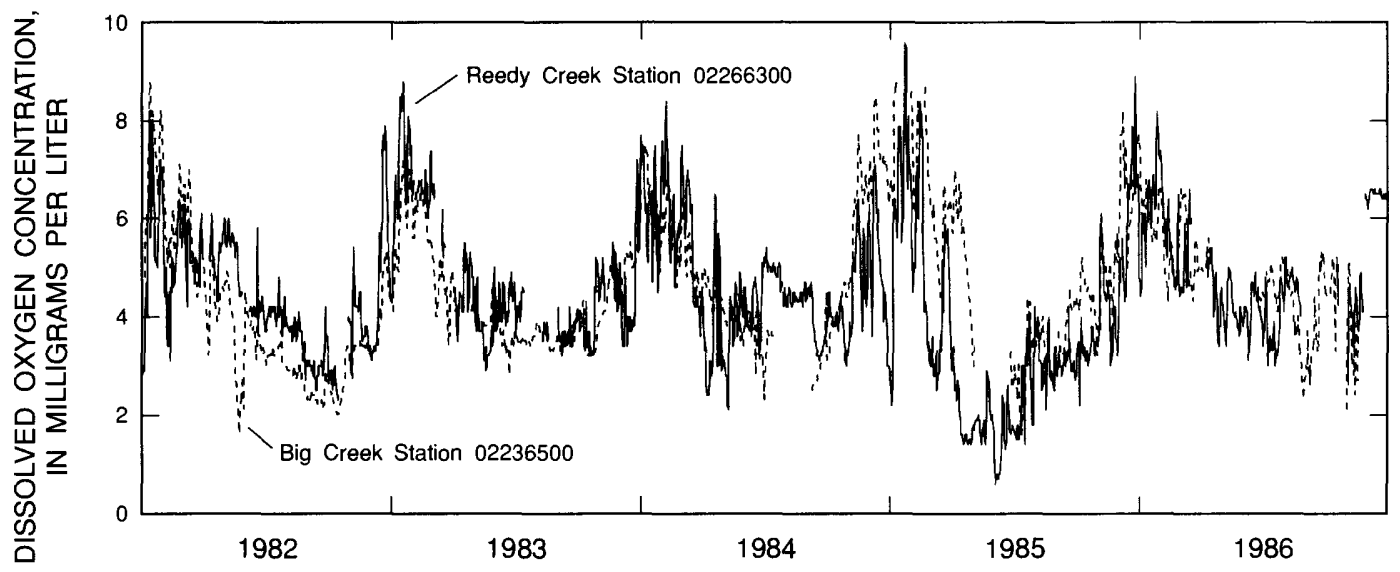

Figure 24. Daily mean dissolved oxygen concentrations for Reedy Creek near Vineland and Big Creek near Clermont, 1982-86.

Dissolved oxygen concentrations at stations 02236500 (Big Creek) and 02266300 (Reedy Creek) followed similar seasonal patterns and exceeded the $5.0 \mathrm{mg} / \mathrm{L}$ minimum standard a similar percent of the time. Daily mean dissolved oxygen concentrations at the two stations for the period 1982-86 are shown in figure 24 . Concentrations at both stations vary seasonally from 1 to $3 \mathrm{mg} / \mathrm{L}$ during the warm summer months to highs from 8 to $10 \mathrm{mg} / \mathrm{L}$ during the cooler winter months. Differences between mean dissolved oxygen concentrations at the two stations primarily reflect short-term differences in rainfall and discharge conditions. Dissolved oxygen duration on exceedance curves for station 02266300 (Reedy Creek) for the entire period of record and for stations 02236500 (Big Creek) and 02266300 (Reedy Creek) for their common period of record are shown in figure 25. Dissolved oxygen concentrations at station 02266300 (Reedy Creek) were lower for the period 1982-88 than for the entire period of record (1980-89) and also were lower than concentrations at station 02236500 (Big Creek)During 1982-88, dissolved oxygen concentrations at station 02236500 (Big Creek) followed a frequency pattern almost identical to that of dissolved oxygen at station 02266300 (Reedy Creek) for the whole period of record.

From 1983 through 1989, hourly dissolved oxygen concentration data were collected at four stations on Reedy Creek. A summary of daily mean dissolved oxygen concentration for the four Reedy Creek stations are given in table 11 .
The lowest daily mean dissolved oxygen concentrations during 1983-89 generally were at station 022662947 which, with the exception of the period July 1988 through February 1989, was upstream from any active wastewater-discharge points into Reedy Creek. Between July 1988 and February 1989, however, wastewater was discharged from station RC23 (fig. 10) upstream from station 022662947. During the period of RC23 operation, the wastewater discharge apparently lowered dissolved oxygen concentrations at station 022662947. Dissolved oxygen concentrations were significantly lower during this period than for the same months in the other years of data collection. The mean dissolved oxygen concentration during the period of wastewater discharge at RC23 was only $2.3 \mathrm{mg} / \mathrm{L}$ which, by analysis of variance with the same months in other years, was significantly different at a probability level of 99 percent. The effect of the wastewater discharge, however, did not extend downstream to station 02266298; an analysis of variance of dissolved oxygen concentrations at that station indicated no significant differences between the July 1988-February 1989 period and the remainder of the study period at any probability level greater than 60 percent. The mean dissolved oxygen concentration at station 022662947 for periods other than July 1988-February 1989 was $4.3 \mathrm{mg} / \mathrm{L}$, which was significantly lower than dissolved oxygen concentrations at stations downstream.

Station 022662947 also had the greatest daily variation (daily maximum minus daily minimum) in dissolved oxygen concentrations, which reflects water 


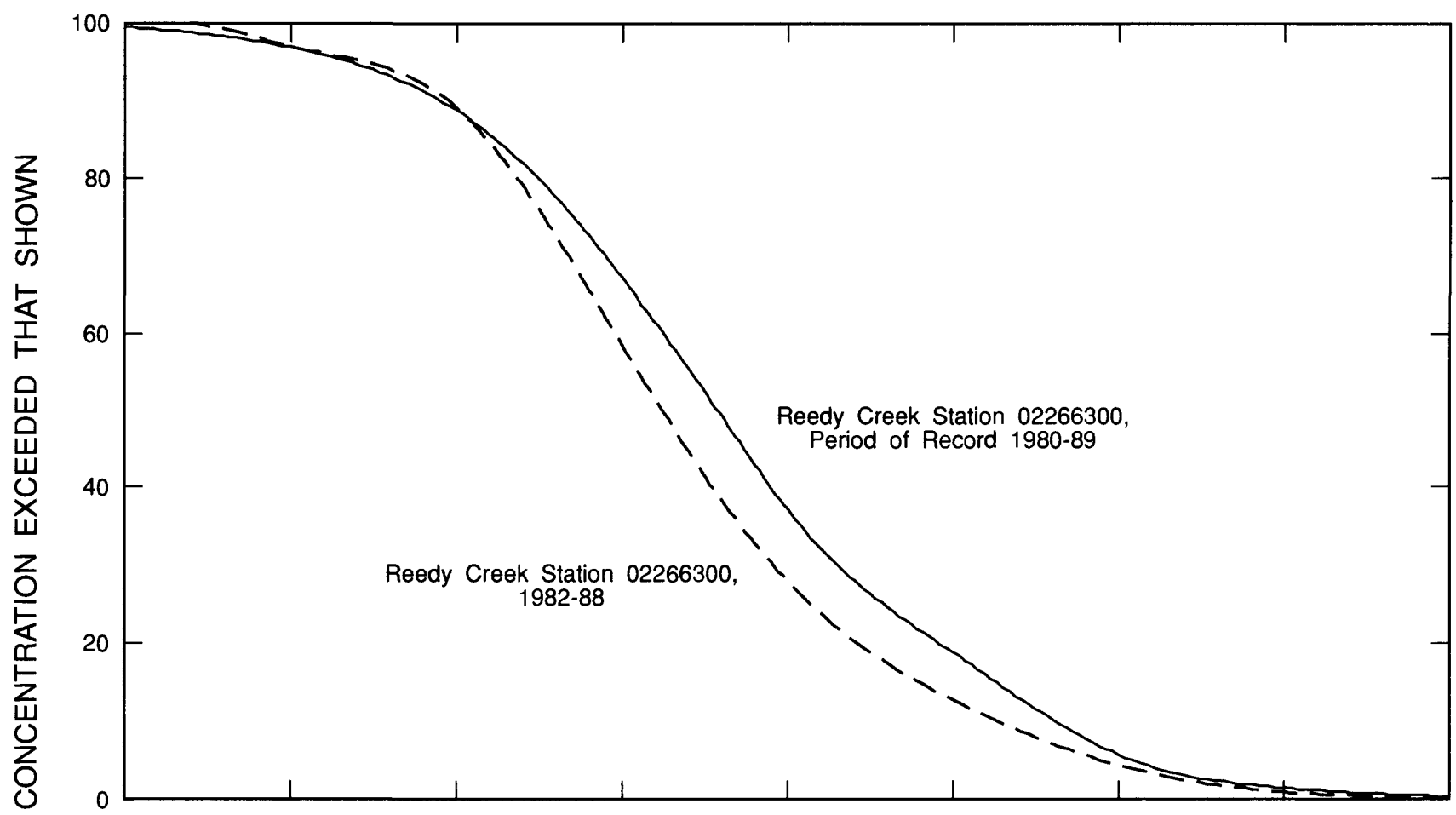

님

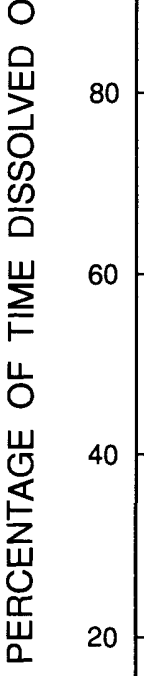

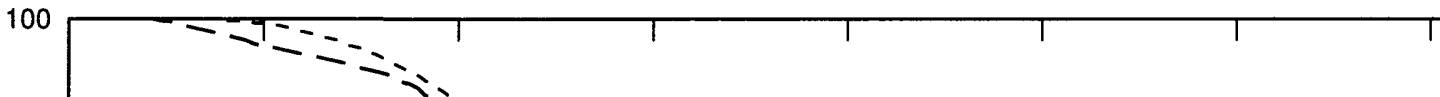

20

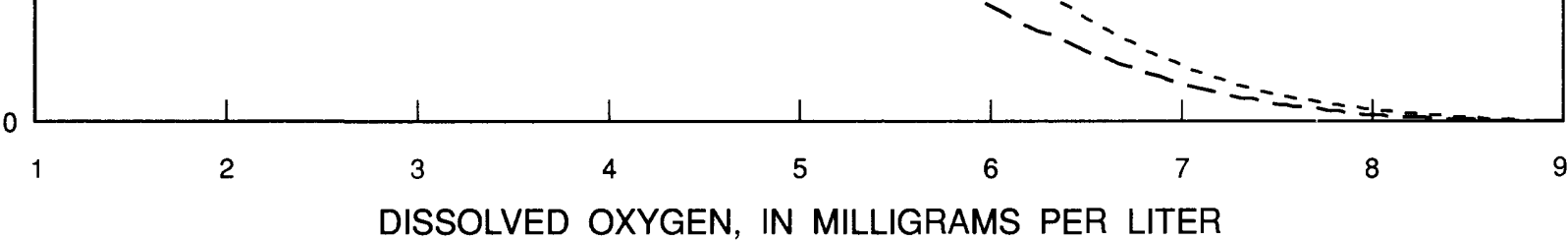

Figure 25. Dissolved oxygen duration curves for Reedy Creek near Vineland and Big Creek near Clermont. 
Table 11. Summary of dissolved oxygen concentrations for stations on Reedy Creek, 1983-89

[All values in milligrams per liter; $\mathrm{mg} / \mathrm{L}$, milligrams per liter]

\begin{tabular}{lccccc}
\hline $\begin{array}{l}\text { Station } \\
\text { number }\end{array}$ & $\begin{array}{c}\text { Mean } \\
\text { daily }\end{array}$ & $\begin{array}{c}\text { Standard } \\
\text { deviation }\end{array}$ & Range & $\begin{array}{c}\mathbf{5 . 0} \text { mg.L } \\
\text { exceedance } \\
\text { (percent) }\end{array}$ & $\begin{array}{c}\text { Mean daily } \\
\text { variation }\end{array}$ \\
\hline 022662947 & 4.2 & 1.9 & $0.2-9.2$ & 3.8 & 1.8 \\
02266298 & 4.6 & 1.4 & $0.3-9.9$ & 36.2 & 0.7 \\
02266300 & 4.5 & 1.4 & $0.6-9.6$ & 32.3 & 0.7 \\
02266320 & 4.7 & 1.4 & $0.4-9.9$ & 33.0 & 0.7 \\
\hline
\end{tabular}

temperature, streamflow, and probably biological conditions at the station. Water temperatures generally are higher at station 022662947 (table 6) than for downstream stations and have greater daily fluctuations because of the greater exposure to direct sunlight and the relatively sluggish flow that is characteristic of Reedy Creek at this station. These conditions also are more favorable for algal production. Algae produce oxygen by photosynthesis and consume oxygen by respiration during dark periods, probably accounting in part for the greater daily range in dissolved oxygen concentration.

Dissolved oxygen concentrations at stations 02266298, 02266300, and 02266320 (fig. 10), located downstream from all wastewater discharges to Reedy Creek, generally were similar during 1983-89 and typically differed by only a few tenths of a milligram per liter. Monthly mean dissolved oxygen concentrations for 1984-88 are shown in figure 26 and illustrate the changes in dissolved oxygen concentrations as water moves downstream in Reedy Creek. Generally, dissolved oxygen concentrations decrease between stations 02266298 and 02266300 and then increase between stations 02266300 and 02266320 . Dissolved oxygen concentrations on average decreased $0.1 \mathrm{mg} / \mathrm{L}$ between stations 02266298 and 02266300 for days of common record, with a range of differences from a $3.7-\mathrm{mg} / \mathrm{L}$ decrease to a $3.9-\mathrm{mg} / \mathrm{L}$ increase. Generally, the larger decreases in dissolved oxygen concentrations were associated with periods of low flow (less than 20 $\mathrm{ft}^{3} / \mathrm{s}$ ) and with smaller storms (peak discharges of less than $40 \mathrm{ft}^{3} / \mathrm{s}$ ). The larger increases in dissolved oxygen concentrations were associated with high-flow periods and with larger storms (peak discharges greater than $100 \mathrm{ft}^{3} / \mathrm{s}$ ). Dissolved oxygen concentrations increased between stations 02266300 and 02266320 on average about $0.1 \mathrm{mg} / \mathrm{L}$ and generally were inversely related to differences between the upstream stations 02266298 and 02266300 . For example, when dissolved oxygen concentrations decreased between stations 02266298 and 02266300 , concentrations generally increased by a similar or greater amount between stations 02266300 and 02266320 . When dissolved oxygen concentrations increased significantly between stations 02266298 and 02266300 , concentrations generally decreased between stations 02266300 and 02266320 .

The differences in dissolved oxygen concentrations between the stations on Reedy Creek also are indicated by the dissolved oxygen duration curves shown in figure 27 . These curves indicate the wider variation and lower average dissolved oxygen concentrations typical of station 022662947 and the similarity of the stations downstream from the wastewaterdischarge points. Of the downstream stations, station 02266320 usually has the highest dissolved oxygen concentration. The curves also indicate the greater variation in dissolved oxygen concentrations at station 02266298 relative to station 02266300 . In the middle range (from 3.5 to $5.5 \mathrm{mg} / \mathrm{L}$ ), dissolved oxygen concentrations usually are slightly greater at station 02266298 than at station 02266300 .

Diel fluctuations in hourly dissolved oxygen concentrations at Reedy Creek stations were similar (fig. 28) during the periods November 8-11, 1988, and April 22-24, 1989. The hourly variations generally reflect the combined influences of water temperature changes and changes in the photosynthetic production of oxygen. Daily maximum concentrations generally are between 11:00 a.m. and 1:00 p.m., when photosynthetic activity is increasing and water temperatures have not yet reached afternoon maximums. Daily minimum concentrations usually are in the late evening and early morning hours between 10:00 p.m. and 2:00 a.m. The data in figure 28 also indicate the phase difference in the daily cycle which is typical between the stations on Reedy Creek. Maximums and minimums at station 


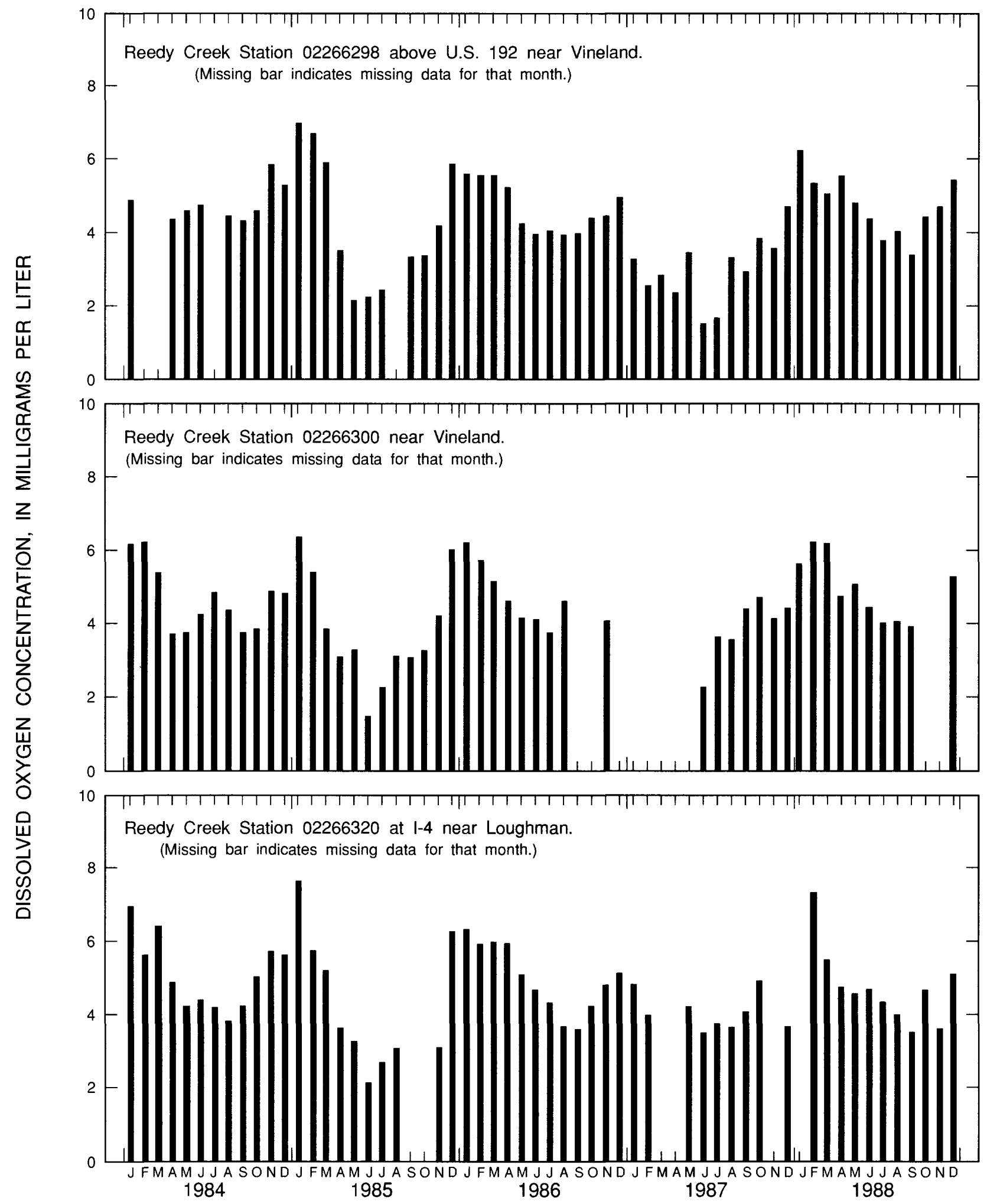

Figure 26. Monthly mean dissolved oxygen concentrations for stations 02266298,02266300 , and 02266320 on Reedy Creek, 1984-88. 


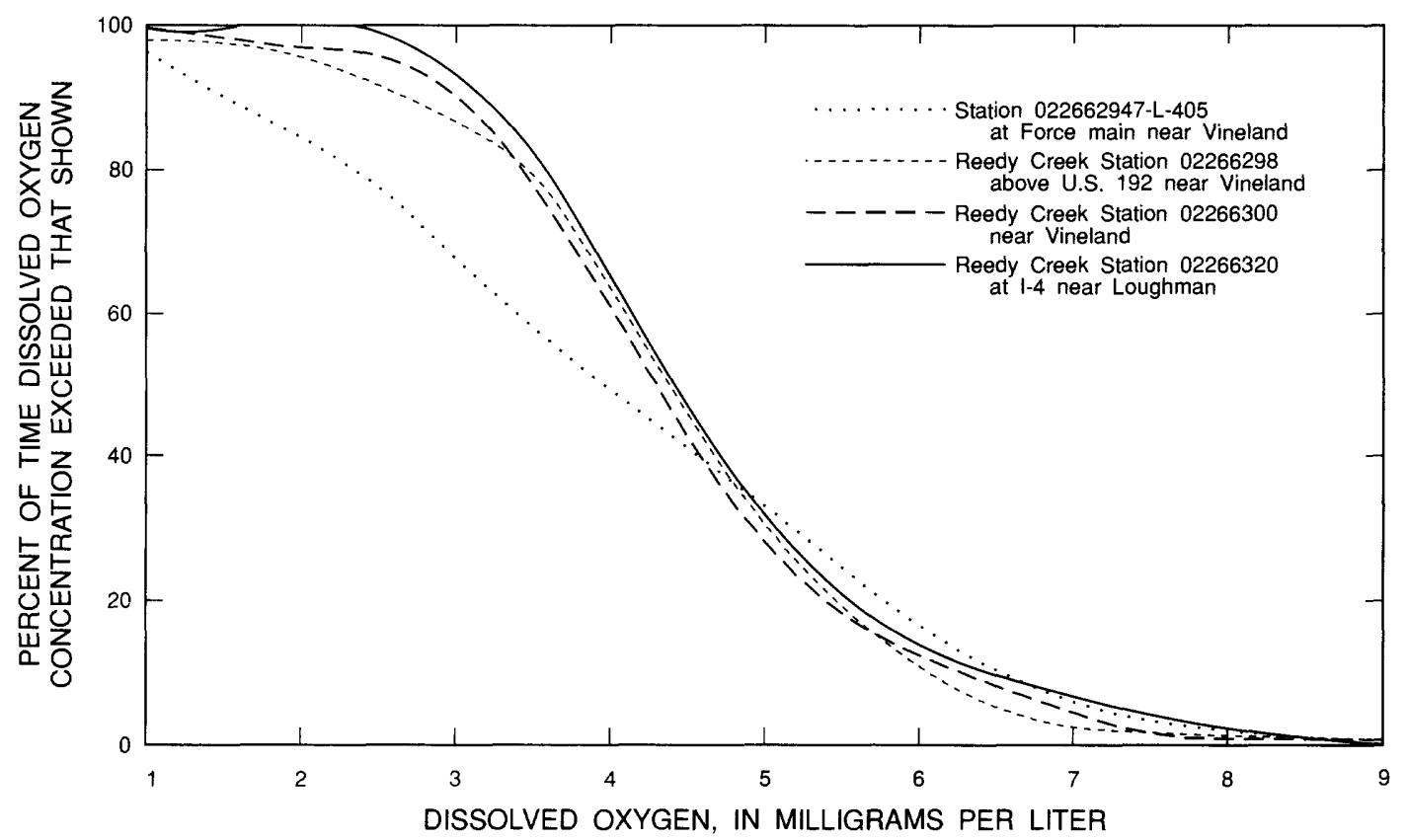

Figure 27. Dissolved oxygen duration curves for stations $022662947,02266298,02266300$, and 02266320 on Reedy Creek, 1963-89.

02266298 generally precede maximums and minimums at station 02266300 , which, in turn, generally are either in phase with or slightly precede maximums and minimums at station 02266320 . These phase differences probably reflect slight differences in biological activity between stations and also possible differences in dissolved oxygen transport from the areas upstream. As indicated in table 11, the average daily variation in dissolved oxygen concentrations for the three stations downstream from the wastewater discharge into Reedy Creek was $0.7 \mathrm{mg} / \mathrm{L}$ during 1983-89, which is similar to the variation at the background station 02236500 .

Dissolved oxygen concentrations in Reedy Creek are affected by storm events in a manner which varies with the size of the storm event. The effects from storms of different sizes are shown in figures 29, 30, and 31 . For very large events (producing a peak discharge greater than $\left.400 \mathrm{ft}^{3} / \mathrm{s}\right)$, such as that shown in figure 29 for November 3-4, 1987, dissolved oxygen concentrations markedly increase during the initial rise in discharge but then quickly decrease to levels below the concentrations which preceded the storm. The increase probably is due to the passage of highly aerated precipitation and initial runoff from areas adjacent to the stream. The subsequent decrease probably reflects the arrival of runoff from the wetland areas and from less frequently flooded areas which drain much more slowly and are characterized by higher oxygen demand. During large storms, the diel dissolved oxygen cycle typical of more uniform flow conditions usually is overshadowed by the large variations in dissolved oxygen concentrations resulting from the storm. Dissolved oxygen concentrations during large storms generally increase between stations 02266298 and 02266300 (fig. 29) because of increased velocity during high flows that results in reaeration within individual stream reaches.

The effect of a moderate storm (peak discharge between 100 and $400 \mathrm{ft}^{3} / \mathrm{s}$ ) on dissolved oxygen concentrations are indicated by the data shown in figure 30 for October 11-13, 1987. Dissolved oxygen concentrations sharply increase during the initial rise in discharge, fall sharply as discharge continues to rise, then begin a gradual increase followed by a gradual decline during the later part of the hydrograph recession, finally reaching dissolved oxygen concentrations lower than those which preceded the storm. As with very large storms, the first increases in dissolved oxygen concentrations probably are associated with aerated precipitation input and with runoff from immediately adjacent areas. The decrease in dissolved oxygen concentrations that follow probably are the result of runoff from the slowly draining wetland areas and the associated high oxygen demand. Runoff from these areas is 

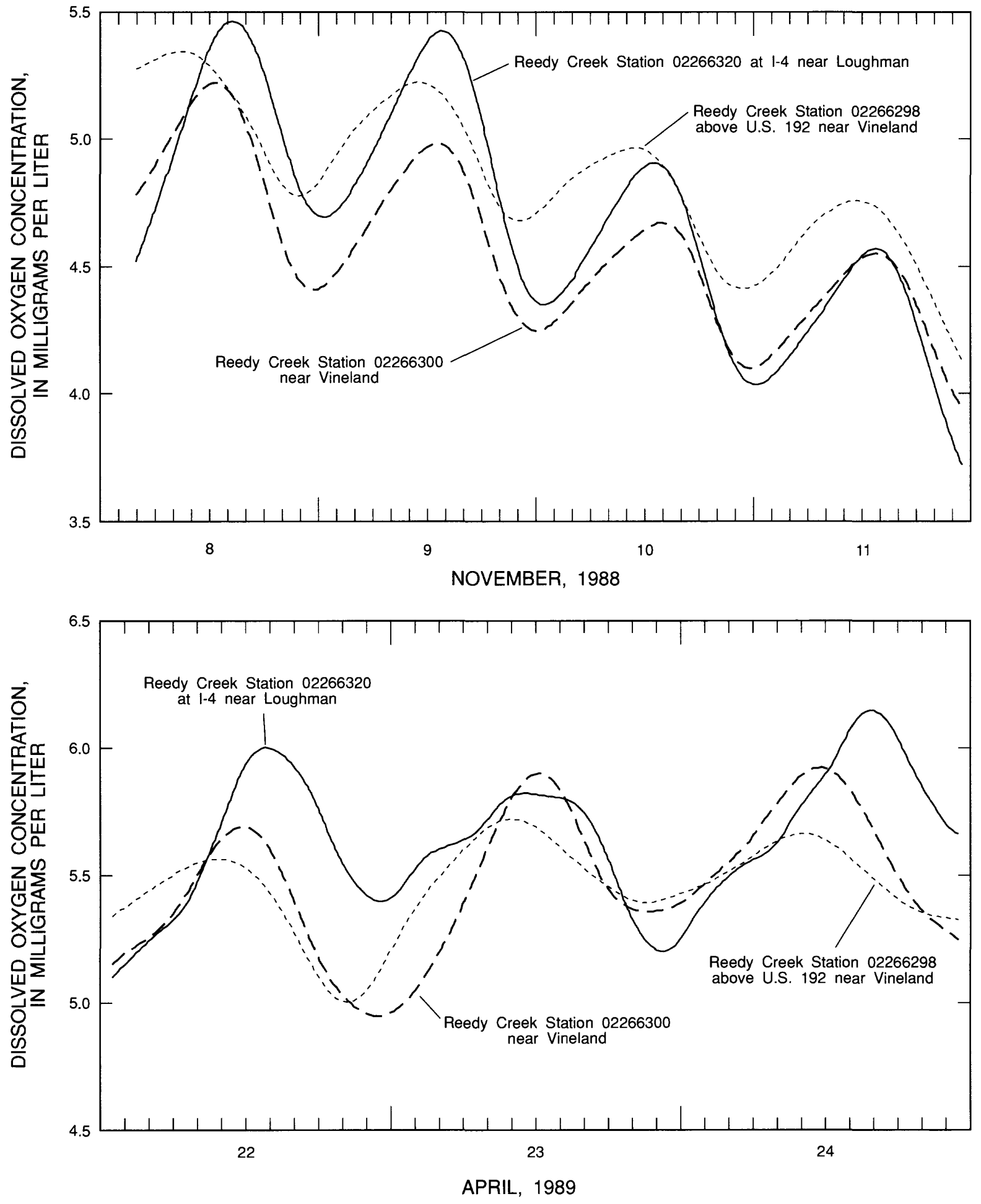

Figure 28. Hourly dissolved oxygen concentrations for three stations on Reedy Creek, November 8-11, 1988, and April 22-24, 1989. 

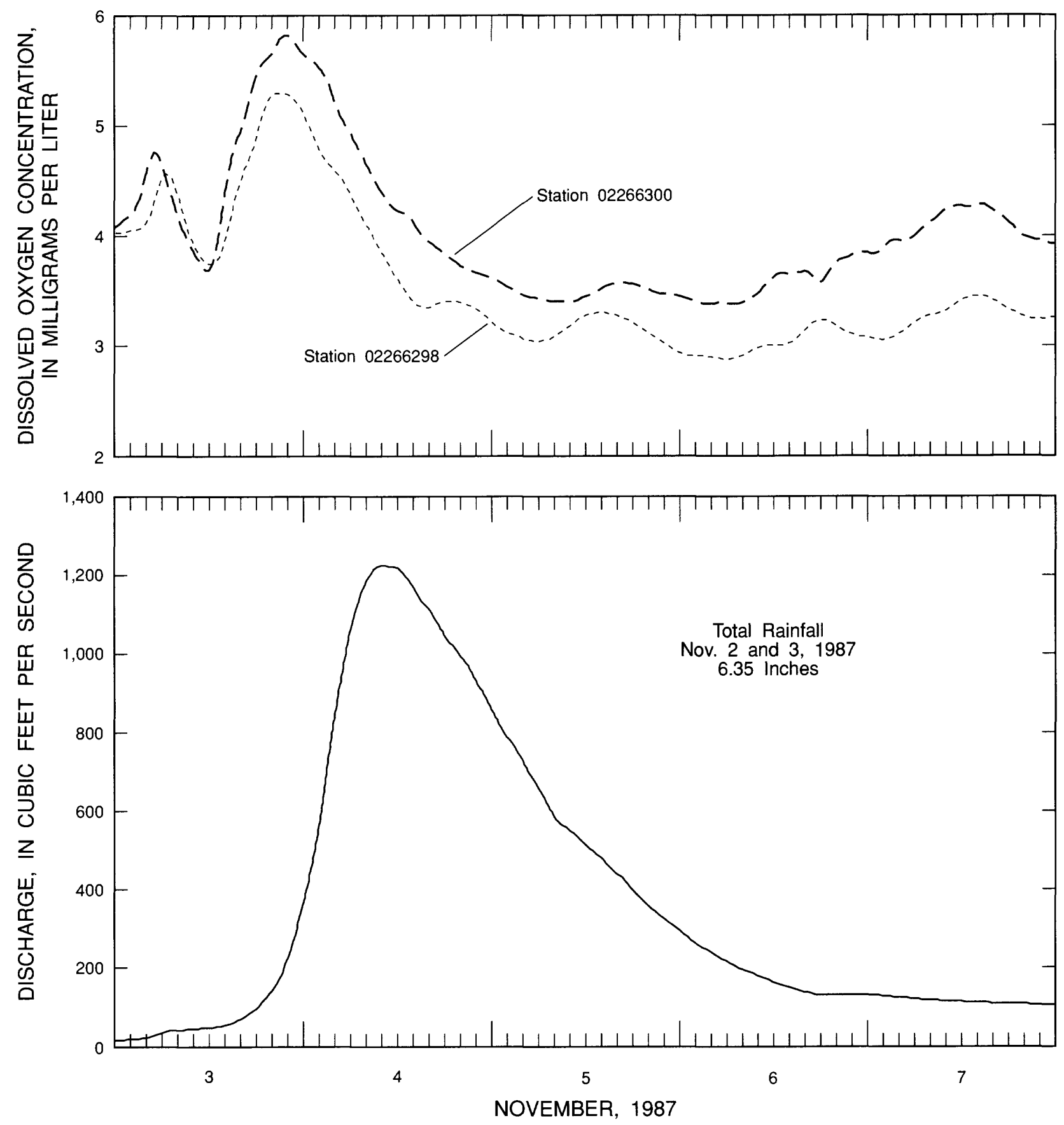

Figure 29. Dissolved oxygen concentrations at stations 02266298 and 02266300 on Reedy Creek during a large storm on November 3-7, 1987. 
much less for a moderate storm than for a large storm, and arrives downstream much later. Diel variations during moderate storms generally are disturbed but not completely overshadowed, and discharges greater than about $30 \mathrm{ft}^{3} / \mathrm{s}$ at station 02266300 result in some increased reaeration as indicated by the increase in dissolved oxygen between stations 02266298 and 02266300 .

The effects of smaller storms (peak discharges of less than $100 \mathrm{ft}^{3} / \mathrm{s}$ ) on dissolved oxygen concentrations are shown in figure 31 for April 14-19, 1989. These results generally parallel those given by German (1986) for two storms in February 1981 that resulted in peak discharges of less than $60 \mathrm{ft}^{3} / \mathrm{s}$. As with large and moderate storms, dissolved oxygen concentrations during smaller storms increase sharply during the initial increase in discharge. During small events, however, dissolved oxygen concentrations usually decrease as the floodwaters pass. Diel variations are typically disturbed only for a short period and the stream reaeration capacity is not greatly enhanced. During events of this magnitude, Reedy Creek remains completely confined to the stream channel and direct surface runoff is minimal following the initial stages of the storm. Ground-
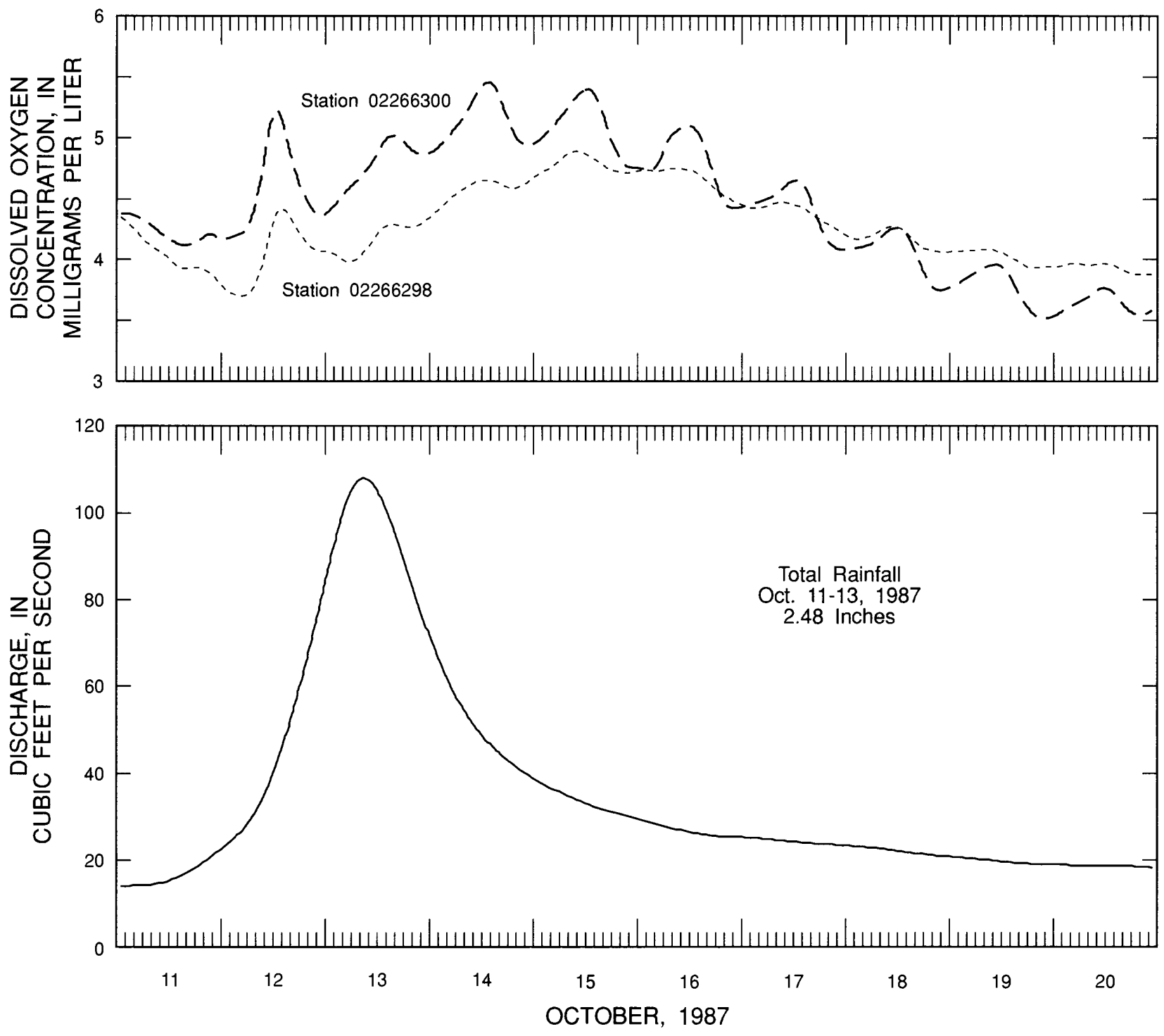

Figure 30. Dissolved oxygen concentrations at stations 02266298 and 02266300 on Reedy Creek during a moderate storm on October 11-13, 1987. (Discharge and rainfall recorded at Station 02266300 , Reedy Creek near Vineland.) 

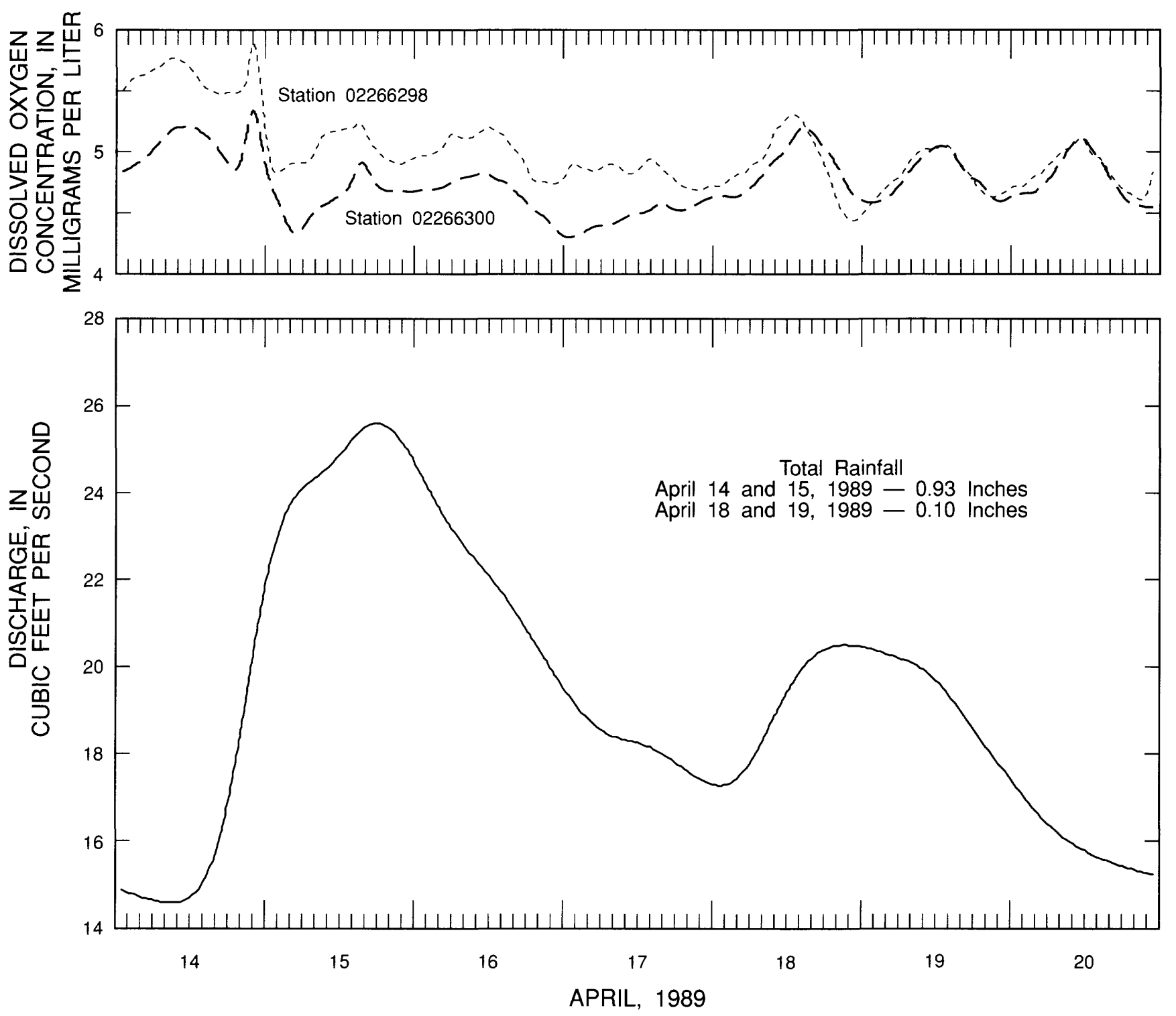

Figure 31. Dissolved oxygen concentrations at stations 02266298 and 02266300 on Reedy Creek during two small storms on April 14-15 and April 18-19, 1989.

water seepage is probably a more important component of streamflow for small storms than for larger storms. The decreased dissolved oxygen concentrations during the smaller storms probably reflect the inflow of ground water with little or no dissolved oxygen.

\section{Nutrients}

Nutrients are those chemical constituents in water that contribute to the productivity of the aquatic ecosystem--the ability of the water to support plant and animal life. The primary nutrients in natural water bodies are the compounds of nitrogen and phosphorus.
Excessive nutrient concentrations can stimulate some organisms to proliferate and can increase the amounts of oxygen-demanding materials present, resulting in the depression of dissolved oxygen concentrations and adversely affecting higher organisms such as fish. Nutrient concentrations generally control the production of organic carbon in aquatic ecosystems.

Acceptable nutrient concentrations can vary widely among different water bodies because of the effects on productivity by other factors, such as stream morphology, trace-metal concentrations, turbidity, and color. No specific nutrient concentration criteria have 
been established for Florida water, but FDER regulations require that "in no case shall nutrient concentrations in a body of water be altered so as to cause an imbalance in natural populations of aquatic flora or fauna" (Florida Department of Environmental Regulation, 1983).

\section{Nutrient and Organic Carbon Concentrations}

Nutrient concentrations were determined in water samples collected quarterly by the USGS at eight stations and more frequently at stations for which load estimates were to be computed. Summary statistics for these data are given in table 12. Station locations are shown in figure 2.

Mean total ammonia nitrogen concentrations were low $(0.04 \mathrm{mg} / \mathrm{L}$ or less $)$ at stations upstream from the RCID wastewater discharges and generally were not affected by these discharges. An exception was station 02266294, located immediately upstream from the wastewater discharge points on Reedy Creek. Higher total ammonia concentrations at this station were also reported by German (1986) and probably reflect anaerobic decomposition of plant debris on the canal bottom. The canal system upstream and downstream from station 02266294 is characterized by very sluggish flow and low dissolved oxygen concentrations. Structure S-405, immediately upstream from the station, is equipped with a leaf trap which probably has contributed to the relatively large accumulation of plant detritus on the canal bottom just upstream from the structure. Total ammonia nitrogen concentrations generally were higher at station 02266297 downstream from the wastewater discharges from the north and south wetland areas than at station 02266294, probably because of the treated-waste inflow. Total ammonia concentrations decreased downstream from station 02266297. Concentrations were lower at stations 02266300 and 02266500 than at station 02266297 , but remained higher than concentrations in samples from Bonnet Creek watershed (station 02264100). The higher total ammonia nitrogen concentrations in the Reedy Creek watershed probably result from both the inflow of treated wastes and the greater percentage of wetland areas that favor the development of anaerobic conditions and ammonia production in the Reedy Creek basin.

Total organic nitrogen accounted for most of the total nitrogen at all stations, with mean concentrations ranging from $0.97 \mathrm{mg} / \mathrm{L}$ at station 02264100 to
$1.61 \mathrm{mg} / \mathrm{L}$ at station 02266200 . Total organic nitrogen concentrations at stations 02266297,02266300 , and 02266500 (all upstream from the wastewater discharges) were slightly higher than concentrations at most other stations but accounted for a significantly lower percentage of the total nitrogen at these stations. On average, total organic nitrogen accounted for 67.1 percent of total nitrogen at station $02266297,60.6$ percent at station 02266300 , and 70.2 percent at station 02266500 . At stations 02264000,02266200 , and 02264100 , total organic nitrogen on average accounted for more than 90 percent of total nitrogen and at station 02266294, more than 80 percent.

Mean total nitrate concentrations at stations upstream from the wastewater discharge points were low $(0.13 \mathrm{mg} / \mathrm{L}$ or less), with the exception of station 02266480 where total nitrate concentration averaged $1.4 \mathrm{mg} / \mathrm{L}$. High nitrate concentrations were also observed at this station in the earlier study by German (1986) and probably result from seepage from the surficial aquifer as well as direct runoff from the citrus groves adjacent to the stream. Fertilizer applications to the groves might have increased the nitrate content of ground water in the surficial aquifer in this area. The higher mean total nitrate concentrations at stations 02266297 and 02266300 probably were the result of wastewater discharges upstream from these stations. The increase in total nitrate nitrogen between these stations could reflect an additional source of nitrate nitrogen, or nitrification of ammonia and organic nitrogen. Although total nitrate concentrations in water from Davenport Creek (02266500) were relatively high $(1.4 \mathrm{mg} / \mathrm{L})$, mean total nitrogen concentrations decreased farther downstream at station 02266500.

Mean total phosphorus concentrations generally parallel the mean total nitrate concentrations with low concentrations $(0.12 \mathrm{mg} / \mathrm{L}$ or less $)$ characteristic of stations upstream from the wastewater discharges. Mean total phosphorus concentrations at the downstream stations 02266297 and 02266300 were higher than at other stations in the study area, probably because of the presence of wastewater inflow. Total phosphorus concentrations increased between these two stations, indicating the presence of an additional source of phosphorus within that reach of Reedy Creek. Orthophosphate phosphorus accounted for most of the total phosphorus at all stations, but accounted for significantly greater proportions at stations downstream from the wastewater-discharge points. 


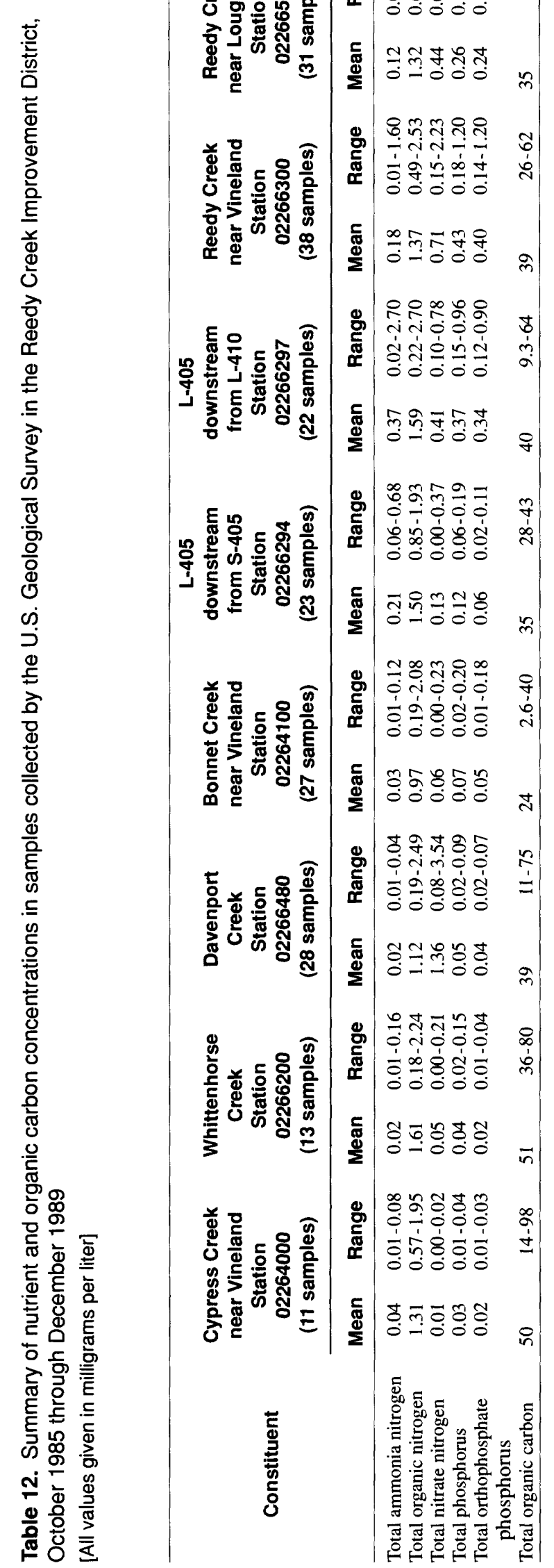




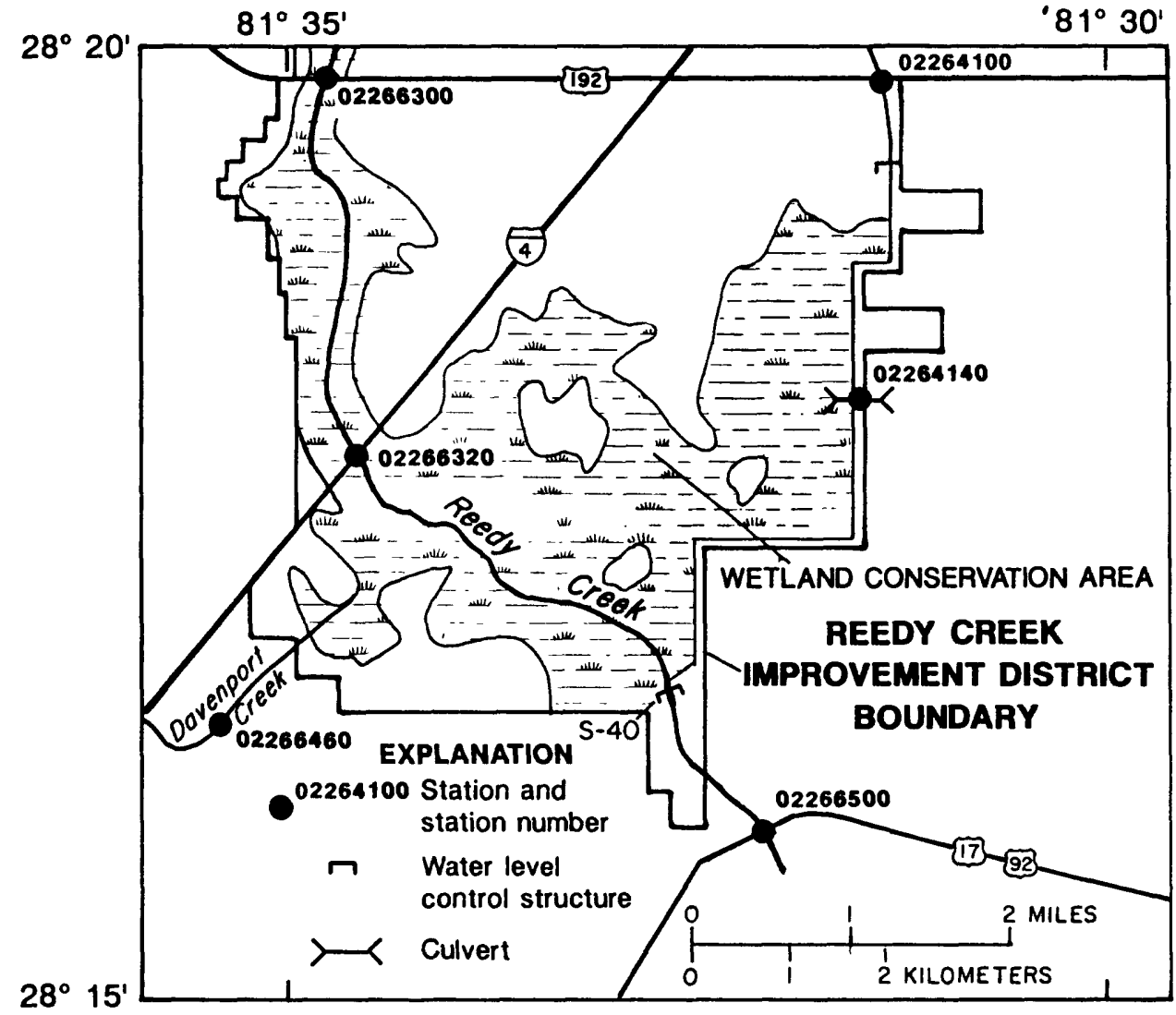

Figure 32. Location of wetland conservation area and stations used for nutrient loading calculations.

The ratio of total nitrogen to total phosphorus also can be indicative of the degree and source of nutrient enrichment. Malcolm and Durum (1970) reported that ratios in natural sources generally averaged $8: 1$ and that ratios less than this could be indicative of influence from sewage inputs. In a study of point and nonpoint discharges into the Chattahoochee River in Georgia, Stamer and others (1979) reported ratios of 6.5:1 for urban, 9.2:1 for rural, and 7.1:1 for forested areas. Ratios of total nitrogen to total phosphorus at stations upstream from the wastewater discharge points in and around the RCID were all in excess of 10:1, ranging from 12:1 for station 0226400 to $50: 1$ for station 02266480 . Ratios for stations downstream from the wastewater discharges were 6.4:1 for station 02266297 , 5.2:1 for station 02266300 , and $7.2: 1$ for station 02266500 . These ratios may indicate that the effect of wastewater discharges probably extends to the southernmost part of the RCID.

Mean total organic carbon concentrations primarily are affected by the amount of forested wetland area in each respective drainage basin. Mean total organic carbon concentrations were highest for stations
0226400 and 02266200 upstream from the RCID and were lowest for stations 02266294 and 02264100 . Total organic carbon concentrations were somewhat higher at station 02266297 than at station 02266294 , but apparently was not markedly increased by wastewater inflows. Total organic carbon concentrations were relatively stable downstream from station 02266294 .

\section{Nutrient Loads Into and Out of the Wetland Conservation Area}

Nutrient loadings into and out of the wetland conservation area within RCID south of U.S. Highway 192 (fig. 32) were estimated for calendar years 1986-89 using multiple regression techniques relating nutrient load to streamflow, time, and season. Discharge into the area was measured at stations 02266300,02264100 , and 02266480 , and drainage from the area was measured at stations 02264140 and 02266500 (fig. 32). Loads were computed by multiplying daily mean discharge on the date of sample collection by the constituent concentration. These loads were then used to determine regression equations based on the minimum 
value of Mallow's Cp. Mallow's Cp is discussed by Draper and Smith (1981). The equations selected for nutrient-load estimation are given in table 13, with values for Mallow's $\mathrm{Cp}$ and the root mean square error for each equation, in percent. Equations were rejected for constituents for which the root mean square error exceeded 30 percent. Annual load estimates for these constituents were calculated using annual mean concentrations applied to daily mean discharges. Load estimates were corrected for possible bias introduced by logarithmic transformations using Duan's smearing estimator (Duan, 1983).

Annual mean discharges (for 1986-89) at the stations for which nutrient loads were computed are given in table 14. Mean daily discharges were determined using stage-discharge relations at all stations except station 02264140 , at which velocities were directly measured using electromagnetic flowmeters for the

Table 13. Equations selected for nutrient load estimate computations

[All equations compute the natural log of the total load, in kilograms. LNQ, natural logarithm of discharge in cubic feet per second; --, missing information indicates mean square error exceeded 30 percent; T, time in days; SINT, sine of time in years, $\mathrm{COST}$, cosine of time in years; $\mathrm{LNQ}^{2}$, square of the natural logarithm of discharge in cubic feet per second]

\begin{tabular}{|c|c|c|c|}
\hline Station number & $\begin{array}{c}\text { Mallow's } \\
\text { Cp }\end{array}$ & $\begin{array}{l}\text { Root mean } \\
\text { square error } \\
\text { (percent) }\end{array}$ & Selected equation \\
\hline \multicolumn{4}{|c|}{ Total ammonia nitrogen } \\
\hline 02264100 & 2.19 & 15.6 & 1.4499LNQ - 4.1055 \\
\hline 02264140 & 2.00 & 18.1 & $1.0252 \mathrm{LNQ}-2.7871$ \\
\hline 02266300 & -- & - & - \\
\hline 02266480 & 5.26 & 17.1 & 1.0016LNQ $-0.3065 \mathrm{~T}-0.0429 \mathrm{SINT}+0.2779 \mathrm{COST}+5.2273$ \\
\hline 02266500 & 2.06 & 29.2 & $0.5412 \mathrm{LNQ}-0.6892$ \\
\hline \multicolumn{4}{|l|}{ Total organic nitrogen } \\
\hline 02264100 & 4.54 & 16.3 & $1.2480 \mathrm{LNQ}-0.1679 \mathrm{~T}+4.7268$ \\
\hline 02264140 & 4.00 & 16.0 & 1.1899LNQ $-0.1271 \mathrm{LNQ}^{2}-0.2016 \mathrm{~T}+5.3559$ \\
\hline 02266300 & 5.15 & 14.3 & 1.7915LNQ - $0.0774 \mathrm{LNQ}^{2}-0.5954$ \\
\hline 02266480 & -. & - & -- \\
\hline 02266500 & 5.00 & 16.9 & $1.1986 \mathrm{LNQ}-0.0248 \mathrm{LNQ}^{2}-0.3496 \mathrm{SINT}+0.0543 \mathrm{COST}+0.8417$ \\
\hline \multicolumn{4}{|l|}{ Total nitrate nitrogen } \\
\hline 02264100 & 4.00 & 19.7 & $1.5443 \mathrm{LNQ}+0.0756 \mathrm{SINT}+1.1519 \mathrm{COST}-3.7818$ \\
\hline 02264140 & -- & -- & - \\
\hline 02266300 & 5.00 & 15.1 & $0.0747 \mathrm{LNQ}^{2}-0.1737 \mathrm{~T}+0.1621 \mathrm{SINT}+0.2935 \mathrm{COST}+7.7520$ \\
\hline 02266480 & 5.00 & 17.2 & $0.0185 \mathrm{LNQ}^{2}-0.1162 \mathrm{~T}+0.1506 \mathrm{SINT}-0.1205 \mathrm{COST}+5.7959$ \\
\hline 02266500 & -- & -- & -- \\
\hline \multicolumn{4}{|l|}{ Total phosphorus } \\
\hline 02264100 & 3.00 & 16.9 & 1.0609LNQ $-0.2137 \mathrm{~T}+3.8834$ \\
\hline 02264140 & 3.17 & 16.0 & $1.0335 \mathrm{LNQ}-0.2016 \mathrm{~T}+3.6973$ \\
\hline 02266300 & 2.00 & 13.9 & $0.8772 \mathrm{LNQ}+0.3284$ \\
\hline 02266480 & 2.45 & 16.7 & $1.0554 \mathrm{LNQ}+2.2232$ \\
\hline 02266500 & 2.00 & 16.4 & $0.9608 \mathrm{LNQ}-0.4770$ \\
\hline \multicolumn{4}{|c|}{ Orthophosphate phosphorus } \\
\hline 02264100 & 4.00 & 20.0 & 1.6569LNQ $-0.749 \mathrm{LNQ}^{2}-0.1512 \mathrm{~T}+1.7796$ \\
\hline 02264640 & 3.88 & 19.4 & $1.0821 \mathrm{LNQ}-0.1633 \mathrm{~T}+1.9981$ \\
\hline 02266300 & 2.00 & 14.1 & $0.8784 \mathrm{LNQ}+0.2327$ \\
\hline 02266480 & 4.00 & 16.7 & $1.1434 \mathrm{LNQ}-0.0218 \mathrm{SINT}-0.2913 \mathrm{COST}-2.7530$ \\
\hline 02266500 & 2.00 & 16.4 & $0.9632 \mathrm{LNQ}-0.5790$ \\
\hline \multicolumn{4}{|l|}{ Total organic carbon } \\
\hline 02264100 & 2.48 & 26.1 & $1.5333 \mathrm{LNQ}+2.4631$ \\
\hline 02264140 & - & -- & - \\
\hline 02266300 & 3.28 & 19.5 & $1.3303 \mathrm{LNQ}+3.3697$ \\
\hline 02266480 & 4.47 & 25.2 & $2.3487 \mathrm{LNQ}-0.1612 \mathrm{LNQ}^{2}-0.1677 \mathrm{~T}+7.1981$ \\
\hline 02266500 & 5.76 & 21.8 & $1.0792 \mathrm{LNQ}-0.1596 \mathrm{~T}-0.2799 \mathrm{SINT}+0.1429 \mathrm{COST}+8.6442$ \\
\hline
\end{tabular}


Table 14. Annual mean discharges into and out of the Reedy Creek Improvement District wetland conservation area, 1986-89

[All values given in cubic feet per second]

\begin{tabular}{|c|c|c|c|c|c|c|c|c|}
\hline \multirow[b]{2}{*}{ Year } & \multicolumn{5}{|c|}{ Inflow discharge } & \multicolumn{3}{|c|}{ Outflow discharge } \\
\hline & $\begin{array}{c}\text { Station } \\
02264100\end{array}$ & $\begin{array}{l}\text { Station } \\
02266300\end{array}$ & $\begin{array}{c}\text { Station } \\
02266480\end{array}$ & $\begin{array}{c}\text { Rainfall minus } \\
\text { potential } \\
\text { evaporation }\end{array}$ & Total & $\begin{array}{c}\text { Station } \\
02264140\end{array}$ & $\begin{array}{c}\text { Station } \\
02266500\end{array}$ & Total \\
\hline 1986 & 23.6 & 41.8 & 11.1 & 0.0 & 176.5 & 36.6 & 40.4 & 77.0 \\
\hline 1987 & 35.3 & & 12.2 & 15.4 & 119 & 43.6 & 74.0 & 118 \\
\hline 1988 & 23.5 & 63.4 & 14.8 & 16.2 & 118 & 41.0 & 77.0 & 118 \\
\hline 1989 & 8.5 & 27.5 & 7.0 & 4.7 & 47.7 & 34.0 & 17.6 & 51.6 \\
\hline
\end{tabular}

period October 1986 through May 1988. Discharges during periods of missing record at this station were estimated using a relation developed between discharge and stage at station 02264100 on Bonnet Creek. Rainfall input was estimated as the difference between measured rainfall at the Kissimmee NOAA station and 45.57 in. of potential evaporation estimated by Visher and Hughes (1975).

The estimated total inflow to the undeveloped area south of U.S. Highway 192 averaged about $89 \mathrm{ft}^{3} / \mathrm{s}$ during 1986-89 and the estimated total outflow averaged about $91 \mathrm{ft} 3 / \mathrm{s}$, both of which are in agreement and compare favorably with similar figures given by German (1989). As with streamflow records given earlier, the discharge values indicate that, for most stations, streamflows were near average in 1986, average to above average during 1987 and 1988, and lower than average during 1989 . During the $1986-89$ period, station 02266300 accounted for 57.5 percent of the inflow discharge; station $02264100,28.4$ percent; and station $02266480,14.1$ percent. Station 02266500 accounted for 57.4 percent of the total discharge from the undeveloped wetlands area; the remaining 42.6 percent of the discharge was through the culverts at station 02264140.

The computed annual loads of nitrogen species at stations 02264100,02266300 , and 02266480 (input to the undeveloped area) and at stations 02264140 and 02266500 (output from the undeveloped area) are given for 1986-89 in table 15. All values are given in metric tons. The input load estimates do not include atmospheric and precipitation contributions. Input loads from these sources are unknown but would result in an increase in the retention of these nutrients by the wetland area.
Total ammonia nitrogen accounted for 5.6 percent of total inflow nitrogen and 2.6 percent of total outflow nitrogen. Overall, the undeveloped area retained 59.6 percent of inflow total ammonia and retained more than 50 percent for each of the four years, 1986-89. Generally, percentages retained were slightly higher for the relatively wet years, 1987-88, than for the drier years, 1986 and 1989. Overall, station 02266300 (Reedy Creek) accounted for 84.5 percent of the total ammonia input and station 02264100 (Bonnet Creek) accounted for 13.2 percent. Total ammonia loads also accounted for a greater proportion of the total nitrogen load at station 02266300 (7.1 percent) than at stations 02264100 (3.4 percent) and 02266480 (1.2 percent).

Total organic nitrogen accounted for 71.5 percent of total inflow nitrogen and 77.8 percent of total outflow nitrogen from the undeveloped area. Station 02266300 accounted for most (63.4 percent) of the total organic nitrogen inflow with stations 02264100 and 02266480 accounting for 26.4 and 10.2 percent, respectively. Percent retention of total organic nitrogen varied widely from year to year, ranging from -9.1 percent retention (a net gain) for the year with the highest rainfall (1988), to 15.5 percent during 1986. During the 1986-89 period, only 3.4 percent of the input total organic nitrogen was retained by the undeveloped wetland area. The relatively dry years of 1986 and 1989 were characterized by a much greater percent retention of total organic nitrogen than were the relatively wet years of 1987-88. German (1989) reported that higher discharges transported the greatest proportion of total organic nitrogen loads in the RCID undeveloped area, and suggested that organic nitrogen was more closely associated with particulates transported during high 
Table 15. Computed annual loads of nitrogen species into and out of the Reedy Creek Improvement District wetland conservation area, 1986-89

[All values are given in metric tons $(1,000$ kilograms $)$ ]

\begin{tabular}{|c|c|c|c|c|c|c|c|c|}
\hline \multirow[b]{2}{*}{ Year } & \multicolumn{4}{|c|}{ Inflow nitrogen load } & \multicolumn{3}{|c|}{ Outflow nitrogen load } & \multirow{2}{*}{$\begin{array}{l}\text { Percent } \\
\text { retained }\end{array}$} \\
\hline & $\begin{array}{l}\text { Station } \\
02264100\end{array}$ & $\begin{array}{l}\text { Station } \\
02266300\end{array}$ & $\begin{array}{l}\text { Station } \\
02266480\end{array}$ & Total & $\begin{array}{l}\text { Station } \\
02264140\end{array}$ & $\begin{array}{c}\text { Station } \\
02266500\end{array}$ & Total & \\
\hline \multicolumn{9}{|c|}{ Total ammonia nitrogen } \\
\hline 1986 & 1.1 & 6.7 & 0.3 & 8.1 & 1.3 & 1.9 & 3.2 & 60.5 \\
\hline 1987 & 2.0 & 9.1 & 0.2 & 11.3 & 1.6 & 2.6 & 4.2 & 62.8 \\
\hline 1988 & 1.1 & 9.3 & 0.2 & 10.6 & 1.5 & 2.9 & 4.4 & 58.5 \\
\hline 1989 & 0.4 & 4.4 & 0.1 & 4.9 & 1.2 & 1.1 & 2.3 & 53.1 \\
\hline Totals & 4.6 & 29.5 & 0.8 & $\overline{34.9}$ & 5.6 & 8.5 & $\overline{14.1}$ & $\overline{59.6}$ \\
\hline \multicolumn{9}{|c|}{ Total organic nitrogen } \\
\hline 1986 & 34.3 & 64.7 & 11.1 & 110.1 & 34.3 & 58.7 & 93.0 & 15.5 \\
\hline 1987 & 48.3 & 85.5 & 12.2 & 146.0 & 49.4 & 93.9 & 143.3 & 1.8 \\
\hline 1988 & 25.6 & 88.7 & 14.8 & 129.1 & 36.2 & 104.7 & 140.9 & -9.1 \\
\hline 1989 & 8.9 & 41.8 & 7.0 & 57.7 & 24.0 & 26.4 & 50.4 & 12.7 \\
\hline Totals & 117.1 & 280.7 & 45.1 & 442.9 & 143.9 & 283.7 & 427.6 & 3.4 \\
\hline \multicolumn{9}{|c|}{ Total nitrate nitrogen } \\
\hline 1986 & 2.8 & 31.3 & 6.7 & 40.8 & 2.9 & 15.9 & 18.8 & 53.9 \\
\hline 1987 & 6.3 & 30.6 & 6.1 & 43.0 & 3.5 & 29.1 & 32.6 & 24.2 \\
\hline 1988 & 3.5 & 26.8 & 5.5 & 35.8 & 3.3 & 30.4 & 33.7 & 5.9 \\
\hline 1989 & 1.0 & 16.5 & 4.7 & 22.2 & 2.7 & 6.9 & 9.6 & 56.8 \\
\hline Totals & 13.6 & 105.2 & 23.0 & 141.8 & 12.4 & 82.3 & 94.7 & 33.2 \\
\hline \multicolumn{9}{|c|}{ Total nitrogen } \\
\hline 1986 & 38.2 & 102.7 & 18.1 & 159.0 & 51.9 & 76.5 & 128.4 & 19.2 \\
\hline 1987 & 56.6 & 125.2 & 18.5 & 200.3 & 54.5 & 125.6 & 180.1 & 10.1 \\
\hline 1988 & 30.2 & 124.8 & 20.5 & 175.5 & 41.0 & 138.0 & 179.0 & -2.0 \\
\hline 1989 & 10.3 & 62.7 & 11.8 & 84.8 & 27.9 & 34.4 & 62.3 & 26.5 \\
\hline Totals & 135.3 & 415.4 & 68.9 & $\overline{619.6}$ & 175.3 & 374.5 & $\overline{549.8}$ & $\overline{11.3}$ \\
\hline
\end{tabular}

discharge periods. The results also could reflect transport from areas that are inundated only during periods of high discharge, such as occurred in 1987-88.

Total nitrate nitrogen accounted for 22.9 percent of total inflow nitrogen and 17.2 percent of total outflow nitrogen. Most (74.2 percent) of the total nitrate inflow to the area was accounted for by station 02266300 with stations 02264100 and 02266480 accounting for 9.6 and 16.2 percent, respectively. Station 02266480 on Davenport Creek accounted for a higher proportion of the total nitrate input than other nitrogen species because of the enrichment of streamflow with nitrate from ground water. Total nitrate retention paralleled total organic nitrogen retention, with greater retention during the drier years of 1986 and 1989 than during the relatively wet years of 1987-88. Percentages of total nitrate retained ranged from 5.9 percent for 1988 to 56.8 percent for 1989 and averaged 33.2 percent for the entire 4-year period.
Retention of total nitrogen by the undeveloped wetlands area ranged from -2.0 percent (a net gain) in 1988 to 26.5 percent in 1989 . Retention percentages for total nitrogen closely paralleled retention of total organic nitrogen because organic nitrogen was the predominant nitrogen species. Overall, the undeveloped wetland area retained 11.3 percent of the total inflow nitrogen during the period 1986-89.

The computed annual loads of phosphorus species and total organic carbon for stations discharging into and out of the undeveloped wetland area south of U.S. Highway 192 are given in table 16. Station 02266300 accounted for most of the inflow of all three constituents, accounting for 88.2 percent of the total phosphorus inflow, 90.6 percent of the total orthophosphate phosphorus inflow, and 57.6 percent of the total organic carbon inflow. Station 02264100 accounted for 8.7 percent of the total phosphorus, 6.9 percent of the total orthophosphate, and 25.8 percent of the total organic 
Table 16. Computed annual loads of total phosphorus, orthophosphate phosphorus, and organic carbon into and out of the Reedy Creek Improvement District wetland conservation area, 1986-89

[All values are given in metric tons (1,000 kilograms)]

\begin{tabular}{|c|c|c|c|c|c|c|c|c|}
\hline \multirow[b]{2}{*}{ Year } & \multicolumn{4}{|c|}{ Inflow nitrogen load } & \multicolumn{3}{|c|}{ Outflow nitrogen load } & \multirow{2}{*}{$\begin{array}{l}\text { Percent } \\
\text { retained }\end{array}$} \\
\hline & $\begin{array}{l}\text { Station } \\
02264100\end{array}$ & $\begin{array}{l}\text { Station } \\
02266300\end{array}$ & $\begin{array}{c}\text { Station } \\
02266480\end{array}$ & Total & $\begin{array}{l}\text { Station } \\
02264140\end{array}$ & $\begin{array}{l}\text { Station } \\
02266500\end{array}$ & Total & \\
\hline \multicolumn{9}{|c|}{ Total phosphorus } \\
\hline 1986 & 2.2 & 16.8 & 0.6 & 19.6 & 3.5 & 9.5 & 13.0 & 33.7 \\
\hline 1987 & 2.7 & 20.7 & 0.7 & 24.1 & 3.4 & 16.1 & 19.5 & 19.1 \\
\hline 1988 & 1.5 & 21.6 & 0.8 & 23.9 & 2.7 & 17.0 & 19.7 & 17.6 \\
\hline 1989 & 0.6 & 12.1 & 0.4 & 13.2 & 1.9 & 4.9 & 6.8 & 48.5 \\
\hline Totals & $\overline{7.0}$ & 71.3 & 2.5 & $\frac{15.4}{80.8}$ & $\frac{1.8}{11.5}$ & $\frac{4.9}{47.5}$ & $\frac{0.0}{58.0}$ & $\frac{70.0}{27.0}$ \\
\hline \multicolumn{9}{|c|}{ Total orthophosphate phosphorus } \\
\hline 1986 & 1.6 & 15.7 & 0.5 & 17.8 & 2.3 & 8.8 & 11.1 & 37.6 \\
\hline 1987 & 1.9 & 19.4 & 0.5 & 21.8 & 2.3 & 14.9 & 17.2 & 21.1 \\
\hline 1988 & 1.1 & 20.2 & 0.6 & 21.9 & 1.9 & 15.7 & 17.6 & 19.6 \\
\hline 1989 & 0.4 & 11.4 & 0.3 & 12.1 & 1.3 & 4.5 & 5.8 & 52.1 \\
\hline Totals & 5.0 & 66.7 & $\frac{0.0}{1.9}$ & 73.6 & $\frac{1.0}{7.8}$ & $\frac{1 .}{43.9}$ & 51.7 & 29.8 \\
\hline \multicolumn{9}{|c|}{ Total organic carbon } \\
\hline 1986 & 921 & 1,870 & 831 & 3,620 & 819 & 1,980 & 2,800 & 22.7 \\
\hline 1987 & 1,980 & 3,170 & 738 & 5,890 & 975 & 2,980 & 3,960 & 32.8 \\
\hline 1988 & 974 & 2,960 & 810 & 4,740 & 919 & 2,690 & 3,610 & 23.8 \\
\hline 1989 & 197 & 1,090 & 258 & 1,540 & 748 & 577 & 1,320 & 14.3 \\
\hline Totals & 4,070 & 2,640 & 9,090 & $\frac{15,790}{15}$ & 3,460 & 8,230 & 11,690 & 26.0 \\
\hline
\end{tabular}

carbon. Station 02266480 accounted for 3.1 percent of the total phosphorus, 2.6 percent of the total orthophosphate, and 16.7 percent of the total organic carbon inflow to the undeveloped area. Loads of orthophosphate phosphorus accounted for a greater proportion (93.5 percent) of total phosphorus at station 02266300 than at stations 02264100 (71.4 percent) and 02266480 (76.0 percent). Similar differences existed for the outflow stations, with total orthophosphate accounting for 87.5 percent of the total phosphorus discharged through station 02266500 and only 67.8 percent through station 02264140 . Retention of phosphorus species by the undeveloped wetland area paralleled total nitrogen retention, with greater retention during the relatively dry years of 1986 and 1989 than during the wetter years of 1987-88. Overall, the undeveloped area retained 27.0 percent of the total phosphorus input and 29.8 percent of total orthophosphate phosphorus.

Total organic carbon retention more closely paralleled the retention of total ammonia nitrogen than that of total organic nitrogen. Overall, the undeveloped area retained 26.0 percent of the total organic carbon inflow.

\section{Nutrient Concentrations and Loads Associated with Wastewater Discharge to Reedy Creek}

Water samples collected at stations RC18, RC23, 02266297, 02266298, and 02266300 during calendar years 1988-89 also were analyzed for nutrients by the RCID laboratory. Samples were collected almost daily at stations RC18 and RC23 (no samples were collected on weekends) and weekly at the other three stations. Summary statistics of the RCID nutrient analyses are given in table 17. Duplicate qualityassurance samples (for analysis both by the USGS and the RCID laboratories) were collected quarterly during this period at stations 02266297 and 02266300 . Comparative statistics of analytical results for split samples analyzed by both laboratories are given in the appendix.

The analytical results given in table 17 indicate that concentrations of total ammonia nitrogen, total organic nitrogen, and total organic carbon in discharge at station RC23 during its period of operation were much higher than those in discharge from the south wetland at station 02266210 . Wastewater input to the north wetland area had lower concentrations of these 
Table 17. Summary of nutrient and organic carbon concentrations in samples collected in Reedy Creek by the Reedy Creek Improvement District, 1988-89

[All values given in milligrams per liter]

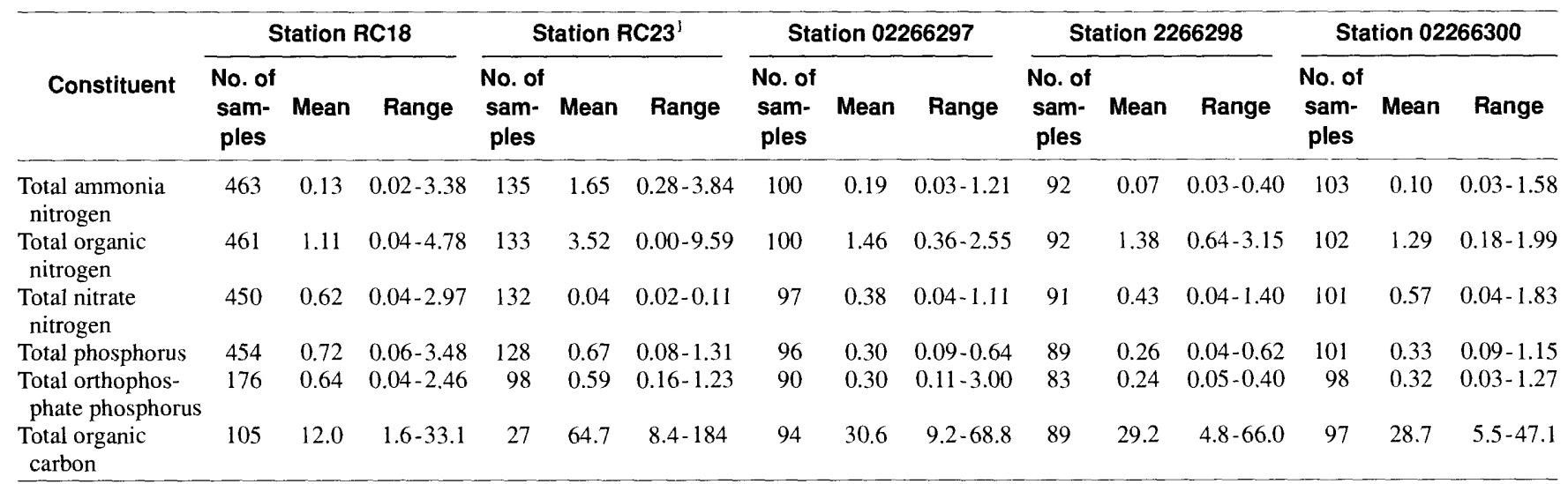

${ }^{1}$ Statistics are for period when flow at station R23 discharged directly to Reedy Creek, July 1988 to February 1989.

constituents (S.P. Merrick, RCID, oral commun., 1991) than did discharge from RC23. The elevated concentrations at RC23, therefore, probably resulted from the release of these constituents to the wastewater as it flowed through the north wetland area. The north wetland area was drained because of construction activities in 1971 and remained a dry forested area until 1988 when wastewater discharges into the area began. The conversion to wet conditions resulted in the death of much of the established dry forest understory vegetation and apparently caused the release of large quantities of nutrients and organic carbon. Concentrations of all nutrient species, including phosphorus, initially were high at station RC23, then generally declined with continuing operation. Concentrations never decreased as much as anticipated, however, and discharges from RC23 were discontinued in early February 1989.

Concentrations of total nitrate nitrogen and phosphorus species at station RC18 (table 17) are higher than those at station 02266297 immediately downstream. These results indicate that $\mathrm{RC} 18$ discharge from the north wetland area that received wastewater input probably served not only as a major source of nitrate and phosphorus, but also resulted in the enrichment of Reedy Creek streamflow with respect to these constituents. Concentrations of total ammonia nitrogen, total organic nitrogen, and total organic carbon at station RC18 are similar to or less than concentrations downstream at station 02266297.
Concentrations of these constituents at station RC18 was similar to concentrations in other wetland areas draining into Reedy Creek.

Concentrations of nitrogen and phosphorus species generally decreased between stations 02266297 and 02266298 , which probably indicates dilution by additional streamflow. An exception is total nitrate nitrogen concentrations which remained relatively uniform in this reach of Reedy Creek. The relatively constant nitrate concentrations, coupled with the decrease in total ammonia nitrogen between these stations, indicate that nitrification of ammonia nitrogen to nitrate nitrogen probably was occurring in this reach of Reedy Creek.

Concentrations of the constituents listed in table 17, except for total organic nitrogen and total organic carbon, generally increased in the reach of Reedy Creek between stations 02266298 and 02266300 , despite increases in streamflow. This indicates that inflow to this reach of the stream is a source of nutrient enrichment, rather than a source of dilution. The reach of Reedy Creek between stations 02266298 and 02266300 is bounded by an extensive wetland area on the east and by the Osceola Services sprayfield on the west. Increased nutrient concentrations could result from the release of previously stored nutrients by the wetland area, runoff and ground-water seepage from the Osceola Services sprayfield, or could indicate the presence of an unknown point source. 
Table 18. Total annual nutrient and organic carbon loadings from the north and south wetlands receiving wastewater effluent and at station 02266300, 1988-89

[All values given in metric tons ( $1,000 \mathrm{kilograms}) ; \mathrm{ft}^{3} / \mathrm{s}$, cubic feet per second]

\begin{tabular}{|c|c|c|c|c|c|c|c|c|}
\hline Year & $\begin{array}{c}\text { Mean } \\
\text { discharges } \\
\left(\mathrm{ft}^{3} / \mathrm{s}\right)\end{array}$ & $\begin{array}{c}\text { Total } \\
\text { ammonia } \\
\text { nitrogen }\end{array}$ & $\begin{array}{c}\text { Total } \\
\text { organic } \\
\text { nitrogen }\end{array}$ & $\begin{array}{c}\text { Total } \\
\text { nitrate } \\
\text { nitrogen }\end{array}$ & $\begin{array}{c}\text { Total } \\
\text { nitrogen }\end{array}$ & $\begin{array}{c}\text { Total } \\
\text { phosphorus }\end{array}$ & $\begin{array}{c}\text { Total } \\
\text { ortho- } \\
\text { phosphate }\end{array}$ & $\begin{array}{c}\text { Total } \\
\text { organic } \\
\text { carbon }\end{array}$ \\
\hline \multicolumn{9}{|c|}{ Total wetlanci outputs (RC23 and RC18) } \\
\hline 1988 & 7.02 & 5.4 & 12.4 & 2.6 & 20.4 & 5.4 & 4.8 & 164.3 \\
\hline 1989 & 6.88 & 1.1 & 8.7 & 3.7 & 13.5 & 2.5 & 2.3 & 109.4 \\
\hline \multicolumn{9}{|c|}{ Station 02266300} \\
\hline 1988 & 57.6 & 3.6 & 70.6 & 22.7 & 96.9 & 13.5 & 13.4 & 2,030 \\
\hline 1989 & 27.5 & 2.5 & 29.1 & 12.2 & 43.8 & 7.1 & 6.9 & 640 \\
\hline
\end{tabular}

Total annual nutrient loadings entering Reedy Creek at stations RC18 and RC23 from the north and south wetland treatment areas were calculated from discharge and nutrient concentration data for 1988-89 furnished by the RCID. Loadings at station 02266300 were calculated from concentrations in samples collected weekly by RCID and USGS discharge data. Nutrient loadings for days with missing concentration data were estimated by interpolation. Total annual estimates were calculated by summation of daily loads and are given in table 18. Attempts to construct regression equations for calculating loads at stations RC18 and $\mathrm{RC} 23$ were unsuccessful and resulted in high values of the root mean square error. Nutrient concentrations and loads at these stations are more dependent upon operational efficiency and the demands placed upon the wastewater treatment plant than upon factors usually used to construct regression equations for less heavily affected stations. Thus, the summation of daily loads probably is a better method for load estimation than the regression equation approach for stations such as these. Annual estimates for station 02266300 using this method differ from the previous estimates based upon regression equations constructed from USGS data. The summation method used probably underestimates load contributions for high discharge periods but is more consistent with the methodology used for stations RC18 and $\mathrm{RC} 23$ and provides a more conservative estimate for assessing the effect of wastewater discharges.

The data for calendar year 1988 (table 18) include data for the period during which discharge from RC23 was characterized by high nutrient concentrations. This is evident in the 1988 load estimates for total ammonia nitrogen which indicate that the total ammonia load discharged from $\mathrm{RC} 18$ and $\mathrm{RC} 23$ exceeded the total ammonia load at station 02266300 , but RC18 and RC23 combined accounted for only 12.2 percent of the flow at station 02266300 . Stations RC18 and RC23 also accounted for about 40 percent of the total phosphorus load at station 02266300 during 1988. During 1989, discharges from the north and south wetland treatment areas accounted for about 25 percent of the total discharge, 31 percent of the total nitrogen, and 35 percent of the total phosphorus loadings at station 02266300. Stations RC18 and RC23 did not serve as sources of total organic carbon enrichment in either 1988 or 1989 , accounting for only 8 and 17 percent, respectively, of the total organic carbon loads at station 02266300 .

Nutrient loads for the common period of discharge record at stations upstream from station 02266300 (fig. 10) are given in table 19. This period includes August through December of 1988 (except at station 02266298) and all of calendar year 1989. Loads for stations 02266297 and 02266298 were calculated by interpolation between sample dates to estimate daily loads on those days for which no samples were collected, followed by summation of the estimated and measured loads for the period. Regression equations were also applied and resulted in slightly, but not significantly, higher results with the same relative proportions of nutrient quantities for both stations.

The 1988 loads given in table 19 reflect the period of operation of RC23 and the high nutrient concentrations discharged from the north wetlands treatment area. The effect of the north wetlands discharge is evident in the total ammonia nitrogen loads for 1988, but also can be seen in the other constituents for which, with the exception of total nitrate, the August through December 1988 total loads are almost equal to total loads for the entire 1989 calendar year. During the August through December 1988 period, discharges at 
Table 19. Nutrient and organic carbon loadings for stations on Reedy Creek, August 1988 through December 1989

[All values given in metric tons $(1,000$ kilograms $) ; \mathrm{ft}^{3} / \mathrm{s}$, cubic feet per second]

\begin{tabular}{|c|c|c|c|c|c|c|c|c|}
\hline Year & $\begin{array}{c}\text { Mean } \\
\text { discharges } \\
\left(\mathrm{ft}^{3} / \mathrm{s}\right)\end{array}$ & $\begin{array}{c}\text { Total } \\
\text { ammonia } \\
\text { nitrogen }\end{array}$ & $\begin{array}{c}\text { Total } \\
\text { organic } \\
\text { nitrogen }\end{array}$ & $\begin{array}{c}\text { Total } \\
\text { nitrate } \\
\text { nitrogen }\end{array}$ & $\begin{array}{c}\text { Total } \\
\text { nitrogen }\end{array}$ & $\begin{array}{c}\text { Total } \\
\text { phosphorus }\end{array}$ & $\begin{array}{c}\text { Total } \\
\text { ortho- } \\
\text { phosphate }\end{array}$ & $\begin{array}{c}\text { Total } \\
\text { organic } \\
\text { carbon }\end{array}$ \\
\hline \multicolumn{9}{|c|}{ Total wetland outputs ( $\mathrm{RC} 23$ and $\mathrm{RC} 18$ ) } \\
\hline 1988 & 8.21 & 4.0 & 7.3 & 0.4 & 11.7 & 2.4 & 2.1 & 96.7 \\
\hline 1989 & 6.88 & 1.1 & 8.7 & 3.7 & 13.5 & 2.5 & 2.3 & 109.4 \\
\hline \multicolumn{9}{|c|}{ Station 02266297} \\
\hline 1988 & 29.7 & 2.6 & 11.9 & 2.4 & 16.9 & 2.2 & 2.2 & 365.7 \\
\hline 1989 & 12.0 & 1.2 & 13.5 & 3.6 & 18.3 & 2.4 & 2.4 & 279.5 \\
\hline \multicolumn{9}{|c|}{$\underline{\text { Station } 02266298}$} \\
\hline 1988 & 45.0 & 0.9 & 21.4 & 2.5 & 23.1 & 2.9 & 2.5 & 558.8 \\
\hline 1989 & 18.5 & 0.9 & 20.5 & 7.3 & 28.7 & 3.7 & 3.3 & 410.7 \\
\hline \multicolumn{9}{|c|}{ Station 02266300} \\
\hline 1988 & 71.7 & 1.8 & 38.5 & 11.2 & 51.5 & 5.9 & 6.2 & $1,151.0$ \\
\hline 1989 & 27.5 & 2.5 & 29.1 & 12.2 & 43.8 & 7.1 & 6.9 & 640.0 \\
\hline
\end{tabular}

RC18 and RC23 accounted for 25.2 percent of the total nitrogen and 32.0 percent of the total phosphorus at station 02266300 , but only 11.5 percent of the streamflow.

During August 1988 to December 1989 (table 19), discharges from the wetland treatment areas accounted for the majority of total nitrogen and phosphorus loads at station 02266297, immediately downstream. Other upstream sources apparently contributed significant quantities of organic nitrogen and most of the total organic carbon. Much of the total ammonia discharged by the wetland systems in the August through December 1988 period was converted to nitrate by the process of nitrification in the reach upstream from station 02266297 , as indicated by the increase in total nitrate nitrogen loads between the wetland outflow points and station 02266297 . This process apparently continued in the reach between station 02266297 and station 02266298, the next station downstream on Reedy Creek (fig. 10). Total ammonia nitrogen loads decreased and total nitrate nitrogen loads increased in this reach during calendar year 1989. Inflows between stations 02266297 and 02266298 also apparently resulted in some streamflow enrichment with respect to total organic nitrogen and total organic carbon. Loads of phosphorus species increased very little between these two stations in the August through December 1988 period. This could reflect phosphorus loadings from station PP7, which drains both the percolation pond area and a nonforested wetland.
During the August through December 1988 period and calendar year 1989, the reach of Reedy Creek between stations 02266298 and 02266300 accounted for the largest increase in streamflow among the monitored reaches and also accounted for a substantial part of the nutrient loads at station 02266300. Relative to the increase in streamflow, the load estimates given in table 19 indicate relative enrichment with respect to total ammonia nitrogen, total nitrate nitrogen, and phosphorus species. Relative enrichment with respect to these constituents was also indicated by the RCID and USGS concentration data (tables 12 and 17). The results indicate that the area that drains to the reach between stations 02266298 and 02266300 probably contributes nutrient loads equal to or greater than those contributed by discharges farther upstream.

\section{SUMMARY AND CONCLUSIONS}

The Reedy Creek Improvement District (RCID) encompasses an area of about 43 square miles in southwestern Orange and northwestern Osceola Counties in central Florida. The area originally consisted largely of uninhabited swampland and scrubby flatland, but much of it has been converted to other uses with the development of the Walt Disney World complex. The RCID maintains and operates a wastewatertreatment plant within the District and discharges much of the treated wastewater to Reedy Creek through forested wetland areas and a percolation pond-wetland 
system. Downstream from the wastewater discharges, phosphorus concentrations in Reedy Creek are relatively high and dissolved oxygen concentrations historically have been low.

Streamflows during 1986-89 generally reflected rainfall patterns, with long periods of below average streamflow interspersed with very high discharges associated with heavy rainfall. Annual rainfall during this period averaged 49.85 inches, slightly above the long-term mean of 49.57 in. For most streams in the RCID, the highest mean discharges were recorded during 1988 and the lowest during 1989. Wastewater discharges into Reedy Creek maintain and increase downstream base flows during low-flow periods. From 1979 to 1989 , discharges from the forested wetland areas that receive wastewater accounted for about 14 percent of the total discharge of Reedy Creek at station 02266300 .

Three traveltime-reaeration coefficient measurements were made on reaches of Reedy Creek using the constant-rate injection method, with propane as the hydrocarbon gas tracer and Rhodamine WT as the dye tracer. The measured reaeration coefficients in Reedy Creek ranged from 6.38 days $^{-1}$ for reach $C$, the most downstream reach, during April 1989, to 13.16 days $^{-1}$ for reach B during August 1988. All of the measured reaeration coefficients were well within the range of values reported for Florida streams. Comparison of the August and November 1988 results indicates that the reaeration coefficients in reaches $A$ and $B$ are very sensitive to discharge conditions in those reaches. Reaeration coefficients generally increase substantially with increased discharge.

Major constituent analyses reflect the general water types present in the RCID area and changes in water-quality as water flows through the District. Inflows to the RCID reflect the swampy, forested wetland character of the drainage basins and consist of soft, acidic, and highly colored waters. An exception is Davenport Creek (station 02266480), which is affected by the irrigation of citrus with water from the Floridan aquifer within the drainage basin. Runoff from the developed areas in the RCID alters the concentrations of major constituents in the area streams, usually resulting in increases in calcium and total alkalinity concentrations and in the buffering capacity of the water. Wastewater discharges increase concentrations of sodium, chloride, color, and total alkalinity in Reedy Creek streamflow, but not to levels that exceed State water-quality standards.
The mean daily dissolved oxygen concentration at station 02266300 for the period $1980-89$ was $4.8 \mathrm{mg} / \mathrm{L}$ and ranged from 0.6 to $9.8 \mathrm{mg} / \mathrm{L}$. Mean daily dissolved oxygen concentrations exceeded the Florida Department of Environmental Regulation's $5.0 \mathrm{mg} / \mathrm{L}$ minimum standard for 38.6 percent of the days during this period. Background dissolved oxygen concentrations were obtained from 1982-88 at station 02236500, Big Creek near Clermont, which is located in an undeveloped basin about 5 miles west of the RCID. Daily mean dissolved oxygen concentrations and water temperatures in Big Creek were very similar to those for stations 02236500 and 02266300 on Reedy Creek during this period. The dissolved oxygen concentrations had similar seasonal ranges from 1 to $3 \mathrm{mg} / \mathrm{L}$ during the summer and early fall and from 8 to $10 \mathrm{mg} / \mathrm{L}$ during the winter. The two stations also had similar daily fluctuations in dissolved oxygen, indicating that biological conditions relative to photosynthetic production of oxygen were similar for the two streams.

Nutrient loadings into and out of the RCID wetland conservation area south of U.S. Highway 192 were estimated for 1986-89 using multiple regression equations relating nutrient load to streamflow, time, and season. Nutrient retention varied widely according to nutrient species and also with rainfall and discharge conditions. Overall retention percentages for the 198689 period, not including atmospheric and precipitation inputs, were 59.6 percent for total ammonia nitrogen, 3.4 percent for total organic nitrogen, 33.2 for total nitrate nitrogen, 11.3 percent for total nitrogen, 27.0 percent for total phosphorus, 29.8 percent for total orthophosphate phosphorus, and 26.0 percent for total organic carbon. For total ammonia nitrogen and total organic carbon, retention was significantly greater during the relatively wet years of 1987-88 than in the relatively dry years of 1986 and 1989. For other nutrient species retention was significantly lower during the wet years. Percent retention for total organic nitrogen ranged from -9.1 percent in 1988 to 15.5 percent in 1986.

Water samples from five stations on Reedy Creek were also analyzed for nutrients. Nutrient loadings at these stations were estimated by summation of daily and weekly loads. During 1988, the forested wetland discharges at stations RC18 and RC23 accounted for about 21 percent of the total nitrogen load and about 40 percent of the total phosphorus load at station 02266300 , but only contributed about 12 percent of the discharge. During 1989, stations RC18 and RC23 
accounted for 31 percent of the total nitrogen load and 35 percent of the total phosphorus load at station 02266300 , but contributed only 25 percent of the total discharge. Stations RC18 and RC23 accounted for only 8 and 17 percent of the total organic carbon loads at station 02266300 for calendar years 1988 and 1989 , respectively. During the common period of record at all five stations, January 1 through December 1989, the reach of Reedy Creek between stations 02266298 and 02266300 accounted for the largest increase in streamflow of any reach as well as a large part of the nutrient loads at station 02266300 . The nutrient-load estimates indicate that (relative to the increase in streamflow) ammonia nitrogen, total nitrate nitrogen, and phosphorus species enrichment occurred in the reach between stations 02266298 and 02266300.

\section{SELECTED REFERENCES}

American Public Health Association, 1985, Standard methods for the examination of water and wastewater (16th ed.): Washington, D.C., 1193 p.

Benson, B.B., and Krause, D., Jr., 1984, The concentration and isotopic fractionation of oxygen dissolved in fresh water and seawater in equilibrium with the atmosphere: Limnology and Oceanography, v. 29, no. 3, p. 620-633.

Draper, N.R., and Smith, Harry, 1981, Applied regression analysis ( $2 \mathrm{~d}$ ed.): New York, John Wiley, 709 p.

Duan, N., 1983, Smearing estimate: a nonparametric retransformation method: Journal of the American Statistical Association, v. 78, no. 383, p. 605-610.

Elmore, H.L., and West, W.F., 1961, Effect of water temperature on stream reaeration: Journal of the Sanitary Engineering Division, Proceedings of the American Society of Civil Engineers, v. 87, no. SA6, p. 59-71.

Fishman, M.J., and Brown, Eugene, 1976, Selected methods of the U.S. Geological Survey for the analysis of wastewaters: U.S. Geological Survey Open-File Report 76-177, $122 \mathrm{p}$.

Florida Department of Environmental Regulation, 1983, Water-quality standards: Chapter 17-3, in Florida Administrative Code: Tallahassee, Fla.

Florida Department of State, 1978, Rules of the Department of Environmental Regulation, water-quality standards, Chapter 17-3, in Florida Administrative Code: Tallahassee, Fla.

German, E.R., 1986, Summary of hydrologic conditions in the Reedy Creek Improvement District, central Florida: U.S. Geological Survey Water-Resources Investigations Report 84-4250, $109 \mathrm{p}$.
1989, Removal of nitrogen and phosphorus in an undeveloped wetland area, central Florida, in Fisk, D.W., ed., Wetlands: concerns and successes, Proceedings of the American Water Resources Association: American Water Resources Association Technical Publication, TBS-89-3, p. 139-148.

Hampson, P.S., 1989, Dissolved-oxygen concentrations in a central Florida wetlands stream, in Fisk, D.W., ed., Wetlands: concerns and successes, Proceedings of the American Water Resources Association: American Water Resources Association Technical Publication, TBS-89-3, p. 149-160.

Hampson, P.S., and Coffin, J.E., 1989, Measurement of reaeration coefficients for selected Florida streams: U.S. Geological Survey Water-Resources Investigations Report 87-4020, $81 \mathrm{p}$.

Kilpatrick, F.A., Rathbun, R.E., Yotsukura, Nobuhiro, G.W., and DeLong, L.L., 1987, Determination of stream reaeration coefficients by use of tracers: U.S. Geological Survey Open-File Report 87-245, 83 p.

Malcolm, R.L., and Durum, W.H., 1970, Organic carbon and nitrogen concentrations and annual organic carbon load of six selected rivers of the United States: U.S. Geological Survey, Water-Supply Paper 1817-F, 21 p.

National Oceanic and Atmospheric Administration, 19301989, Climatological data, Florida annual summaries: Asheville, N.C.

Putnam, A.L., 1975, Summary of hydrologic conditions and effects of Walt Disney World development in Reedy Creek Improvement District, 1966-73: Florida Bureau of Geology Report of Investigations 79, 115 .

Rainwater, K.A., and Holley, E.R., 1984, Laboratory studies on hydrocarbon tracer gases: American Society of Civil Engineers Journal, v. 110, no. 1, p. 27-41.

Rantz, S.E., and others, 1982, Measurement and computation of streamflow, U.S. Geological Survey Water-Supply Paper 2175, vols. 1 and 2, $631 \mathrm{p}$.

Rathbun, R.E., and Grant, R.S., 1978, Comparison of the radioactive and modified techniques for measurement of stream reaeration coefficients: U.S. Geological Survey Water-Resources Investigations 78-68, $57 \mathrm{p}$.

Skougstad, M.W., Fishman, M.J., Friedman, L.C., Erdmann, D.E., and Duncan, S.S., eds., 1979, Methods for determination of inorganic substances in water and fluvial sediments: U.S. Geological Survey Techniques of Water-Resources Investigations, book 5, chap. A1, $626 \mathrm{p}$.

Stamer, J.K., Cherry, R.N., Faye, R.E., and Kleckner, R.L., 1979, Magnitudes, nature, and effects of point and nonpoint discharges in the Chattahoochee River basin, Atlanta to West Point Dew, Georgia: U.S. Geological Survey Water-Supply Paper 2059, 65 p. 
Streeter, H.W., and Phelps, E.B., 1925, A study of the pollution and natural purification of the Ohio River. III. Factors concerned in the phenomena of oxidation and reaeration: Washington, D.C., U.S. Public Health Service, Public Health Bulletin no. 146

Tsivoglou, E.C., 1967, Tracer measurement of stream reaeration: Federal Water Pollution Control Administrative Report, 86 p.
U.S. Environmental Protection Agency, 1985, Rates, constants, and kinetics formulations in surface water quality modeling ( $2 \mathrm{~d}$ ed.): U.S. Environmental Protection Agency Report EPA/600/3-85/040, 455 p.

1986, Quality criteria for water 1986: U.S. Environmental Protection Agency Report EPA/440/5-86/001.

Visher, F.N., and Hughes, G.H., 1975, The difference between rainfall and potential evaporation in Florida (2d ed.): Florida Bureau of Geology Map Series 32. 
Appendix

Comparative water-quality data for USGS and RCID nutrient analyses

Appendix

55 
During the study, duplicate samples were collected on a quarterly basis from selected stations on Reedy Creek and were shipped to both the USGS and RCID water-quality laboratories for analysis of nutrient species. Comparative statistics for duplicate analyses performed during 1988-89 at two stations (02266297 and 02266300), used for computation of load estimates and for duplicate sample collections, are given in table A1. Analytical results from the two laboratories generally were in good agreement for most nutrients. USGS and RCID laboratory results for these constituents are shown in figure Al.

Excellent agreement existed between USGS and RCID analytical results for constituents which are primarily in the dissolved, ionic form, such as total ammonia nitrogen, total nitrate nitrogen, and total orthophosphate phosphorus. The RCID results for orthophosphate phosphorus, however, can be seen in the figure to consistently run about $0.03 \mathrm{mg} / \mathrm{L}$ higher than the USGS laboratory results. Analytical results for constituents that require extensive digestion, such as total organic nitrogen, total phosphorus, and total organic carbon, generally did not agree as well as did other constituents and show more scatter around the line of agreement in the figures. Mean total organic carbon concentrations were not in good agreement largely because of the results for two samples for which USGS reported values were only about half of the values reported by the RCID.

Table A1. Comparative statistics for U.S. Geological Survey and Reedy Creek Improvement District nutrient analytical results [All values given in milligrams per liter)

\begin{tabular}{|c|c|c|c|c|c|c|c|c|}
\hline Constituent & $\begin{array}{c}\text { No. of } \\
\text { samples }\end{array}$ & Mean & $\begin{array}{c}\text { USGS } \\
\text { standard } \\
\text { deviation }\end{array}$ & Range & Mean & $\begin{array}{c}\text { RCID } \\
\text { standard } \\
\text { deviation }\end{array}$ & Range & $\begin{array}{l}\text { Root mean } \\
\text { square } \\
\text { error }\end{array}$ \\
\hline Total Ammonia Nitrogen & 17 & 0.11 & 0.14 & $0.01-0.53$ & 0.12 & 0.13 & $0.04-0.51$ & 0.02 \\
\hline Total organic nitrogen & 16 & 1.58 & 0.51 & $1.00-2.57$ & 1.69 & 0.43 & $1.02-2.51$ & 0.13 \\
\hline Total nitrate nitrogen & 16 & 0.38 & 0.19 & $0.11-0.68$ & 0.40 & 0.21 & $0.14-0.72$ & 0.04 \\
\hline Total phosphorus & 13 & 0.29 & 0.09 & $0.15-0.47$ & 0.33 & 0.08 & $0.19-0.44$ & 0.03 \\
\hline Total orthophosphate phosphorus & 17 & 0.28 & 0.09 & $0.13-0.44$ & 0.25 & 0.09 & $0.12-0.40$ & 0.03 \\
\hline Total organic carbon & 14 & 42.1 & 11.7 & $25-63$ & 36 & 12.6 & $22-63.6$ & 12.1 \\
\hline
\end{tabular}



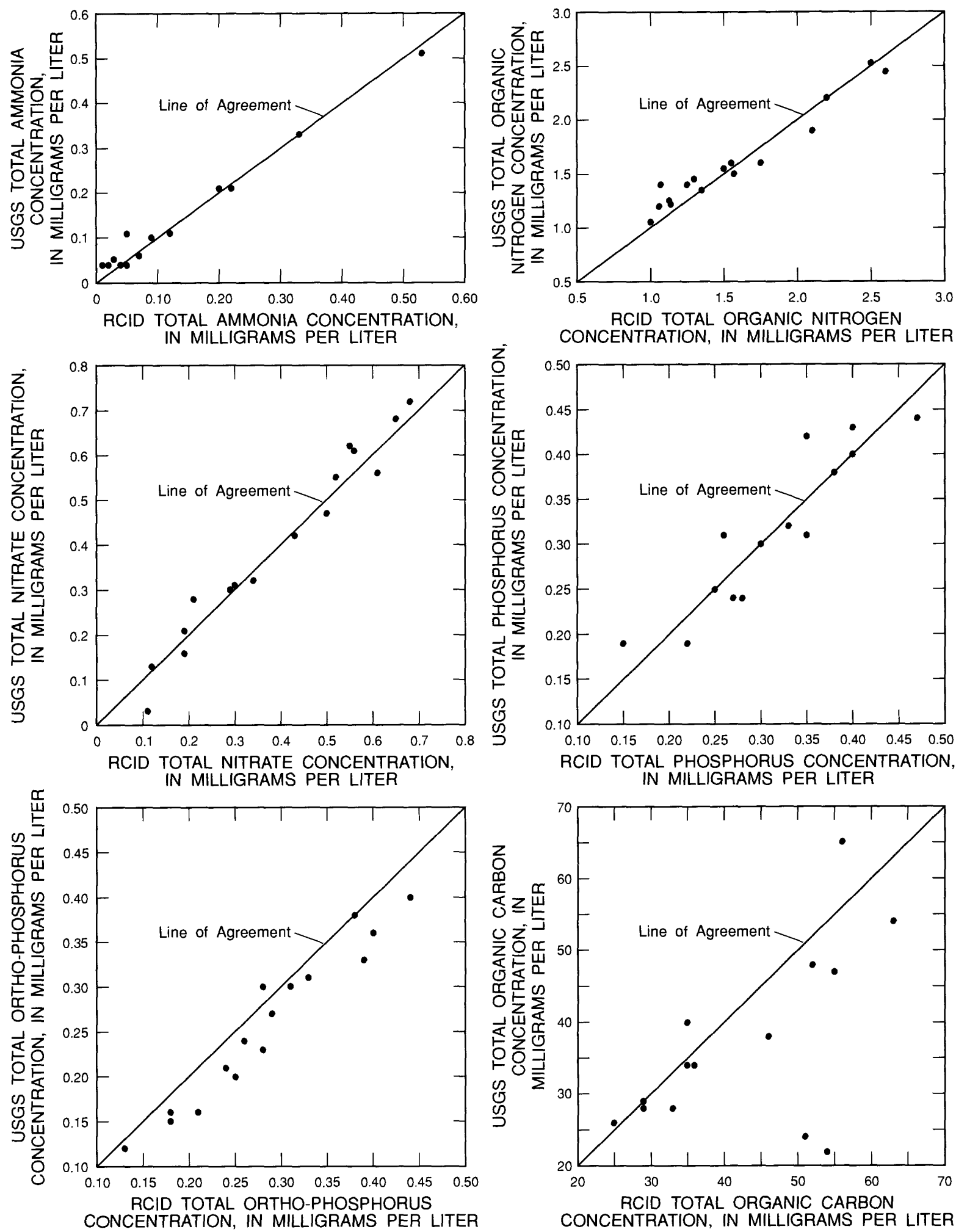

Figure A1. Comparison of nutrient data collected and analyzed by the Reedy Creek Improvement Distrct and the U.S. Geological Survey. 